\title{
Corporate Governance and Profitability of Listed Food and Beverages Firms in Nigeria
}

\author{
Kalu Nnanna Nwonyuku \\ School of Postgraduate Studies, Faculty of Administration, Department of Accounting and Finance, Ahmadu \\ Bello University, Zaria, Kaduna State, Nigeria
}

\begin{abstract}
At its core, the goal of a firm is to create sustainable profitability. And corporate governance should work to ensure this steady increase in corporate performance. Understanding the impact of corporate governance on firm profitability has warranted a special attention over time by different fields of scientific knowledge. This study was aimed to explore the relationship between corporate governance and profitability of firms, employing eight food and beverages firms listed in the Nigerian Stock Exchange from 2004 to 2014. The data were analysed using basic descriptive and inferential statistics with Ordinary Least Square multiple regression in a panel data setting. The results revealed that at 5 per cent level of significance, board size has positive relationship with return on equity and net assets per share. However, board composition has negative relationship with return on equity but with positive association with net assets per share. Board skills and competence has negative relationship with return on equity and net assets per share, while board gender diversity results indicated positive relationship with return on equity and net assets per share. Despite the mixed results, it can be argued that the empirical results support the contention that corporate governance has a positive relationship with profitability of firms. The study recommends among other things, that Nigerian food and beverages firms should adopt effective corporate governance practice as a panacea to firm growth and survival. Further research using corporate governance processes and profitability will not only add value in explaining performance of firms, but also add value to the academic literature.
\end{abstract}

Keywords: corporate governance; board; profitability; food and beverages; listed firms; Nigeria.

\subsection{INTRODUCTION}

\subsection{Statement of Research Problem}

Professor Abraham H. Maslow (1908 - 1970) was indeed right when in 1954 postulated that the physiological needs that influence the behaviour of man to action include hunger and thirst for food and beverages. Ever since, food and beverages have remained the most basic hierarchy of need, and which must be relatively well satisfied before the man is able to function at a higher level. Also, without food and beverages other higher needs will not be met. To leapfrog from the aforementioned, there is clear evidence that food and beverages are largely relied upon by the people of the world. Today, over 7.5 billon people that make up the world population need food and beverages for their survival and effective functioning. Nigeria, in particular, has about 180 million people that rely heavily on food and beverages as the primary source of their motivation to improve performance. Whereas, it is only 23 publicly listed companies on the Nigerian Stock Exchange are involved in the food and beverages business. This presumably suggests for high profitability in the sector following the simple demand and supply mechanisms of economics. This expectation, however, could not be realized as deemed. This contradicting situation is not only found in Nigeria, also, elsewhere in the world. Hence, the question of what should have been the potential influencing factor of profitability in food and beverages firms has long been occupying the mind of many researchers. Also, it has been observed that the international and national business landscapes are rapidly changing; food and beverages sector is not left behind in this direction. "Globalization and technology have continuing speed", manufacturing and trading arenas are becoming more open, "new products and services are flooding the market" and still, some of the food and beverages firms remain permanently in the state of continuously declining profitability. It has been wandered what could be the hope of this industry to remain in business. However, one fact remains that cannot be changed is the need for countries to have sound resilient system of corporate governance that will use competition to strengthen and upgrade their economic sectors to rake high profitability for growth and survival in an increasingly open environment. Corporate governance thus, remains the key factor that is highly depended upon to restoring profitability confidence of firms and keeps the business flagship fluttering and the economy strong, viable and vibrant. This implies that corporate governance is a requisite for survival and a gauge of how predictable the system for doing business in any country is (Oluwafemi, et al. 2013). In developing countries, the importance of corporate governance is to strengthen the foundation of society and chip into the global economy (Matama, 2008). It has also been argued that no firm performance will ever be better than the quality of corporate governance practice that influences it. In other words, corporate governance seems to have the capacity to determine firm profitability. This makes it very crucial and important to study the impact of corporate governance on profitability of firms. Good corporate governance is a critical factor in achieving profitable long - term growth for companies. Nwonyuku (2012a) identifies that all the literature researches consulted have one common fulcrum that by promoting good corporate governance practices, the firm value will 
also increase. More so, past studies and authors have linked corporate governance to profitability (Gompers, et al; 2003; Brown and Caylor, 2004; Sachs, 2007; Selvaggi and Upton 2008; Eisenhofer, 2010; Kashif, 2008; Mutalib, 2012). Many studies have also shown that good corporate governance maximizes the profitability and long - term value of the firm for shareholders, while some other empirical findings suggest contrary to this positive relationship. The correlation between corporate governance and profitability of firms 'are hotly debated issues among managers and scholars.' Further, many researchers have made a number of efforts to explore theoretical models which could be used to improve firm's profitability (Pratheepan, 2014:1) and similar efforts have also been made in corporate governance. Understanding the impact of corporate governance on firm performance is unarguably of the most fertile fields of analysis in strategic management, industrial economists, law, portfolio management, accounting and finance researches. Yet, the extent of corporate governance practice and profitability of food and beverages firms in Nigeria has not been sufficiently investigated. It is as against this background that this study tends to find out whether any linear relationship does exist between corporate governance and profitability for a sample of food and beverages firms listed in the Nigerian Stock Exchange for the period of 2004 to 2014; and looking at the roles of corporate governance proxies: board size, board composition, and board skills and competence, and board diversity with profitability indicators of return on equity and net assets per share.

\subsection{Objectives of Study}

This study is designed to determine whether corporate governance has positive relationship with profitability of food and beverages firms in Nigeria through the following objectives:

1. To test whether size of the board of directors has positive relationship with profitability of food and beverages firms in Nigeria.

2. To test whether board composition is positively associated with the profitability of food and beverages firms in Nigeria.

3. To test whether board skills and competence has positive relationship with profitability of food and beverages firms in Nigeria.

4. To test whether board gender diversity has positive correlation with profitability of food and beverages firms in Nigeria.

\subsection{Research Questions}

In order to gain an insight and understand the nature of relationship between corporate governance and profitability of food and beverages firms in Nigeria, the following questions are addressed in this study.

1. Does size of board of directors have positive relationship with profitability of food and beverages firms in Nigeria?

2. Does board composition positively associate with the profitability of food and beverages firms in Nigeria?

3. Is there a positive relationship between board skills and competence and profitability of food and beverages firms in Nigeria?

4. Is there a positive correlation between board gender diversity and profitability of food and beverages firms in Nigeria?

\subsection{Statement of Research Hypothesis}

In keeping in view the light of research objectives, four hypotheses were formulated and operationalized for analysis and drawing conclusion on the relationship between corporate governance and profitability in the study. HYPOTHESIS ONE

Ho1: The size of the board of directors has negative relationship with profitability of food and beverages firms in Nigeria.

$\mathbf{H}_{\mathbf{A}}$ 1: The size of the board of directors has positive relationship with profitability of food and beverages firms in Nigeria.

\section{HYPOTHESIS TWO}

Ho2: The board composition is negatively associated with the profitability of food and beverages firms in Nigeria.

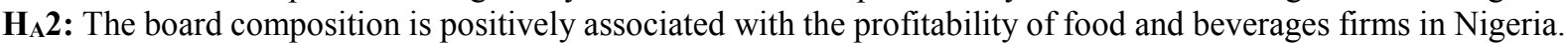
HYPOTHESIS THREE

Ho3: Board skills and competence has negative relationship with profitability of food and beverages firms in Nigeria.

HA3: Board skills and competence has positive relationship with profitability of food and beverages firms in Nigeria.

\section{HYPOTHESIS FOUR}

Ho4: There is negative correlation between board gender diversity and profitability of food and beverages firms in Nigeria.

$\mathbf{H}_{\mathbf{A}} 4$ : There is positive correlation between board gender diversity and profitability of food and beverages firms in 
Nigeria.

\subsection{Delimitation of the Study}

This study is centred on the examination of relationship between corporate governance and profitability of food and beverages firms listed on the floor of Nigerian Stock Exchange (NSE). The research covers the period of 11 years, spanning from 2004 to 2014 . This period was selected in order to examine the post effect of the 2003 code of corporate governance on profitability of firms. The food and beverages sector of Nigeria is selected because of the importance of the industry in producing one of the most essential physiological needs of man. Companies that are not in the food and beverages sector are not included as they have different assets, financing and operational cost requirements as well as profitability benchmark compared to companies under investigation. Further, the spectrum of corporate governance is very wide as it has many determinable elements. Consequently, the study is streamlined to the researcher's interest, relevant and easily measurable characteristics of the corporate governance system of board size, board composition, board skills and competence and board diversity as independent variables. Similarly, the measure of profitability is focused on return on equity and net assets per share as dependent variables and firm size as control variable.

\subsection{Justification and Significance of the Study.}

Inculcating an enduring role of codes of best practices in the corporate world today remains an indelible footprint on the sands of time. Even though it is very challenging, it is a brick which must be laid with strong determination if any economy is serious to be developed. Particularly in Nigeria, where corruption and impunity have anchored in every nook and crane of the economy, the literature of promoting good corporate governance codes remains the only hope of restoring public confidence and to boost competition, marketing, commercialization, profitability, investment stream, and food and beverages firms in particular. Also, as added by Adegbite (2012), this study brings to the fore the need for countries to fashion out their corporate governance regulatory strategies in ways which deal peculiar challenges, albeit within an umbrella behaviour. Even boards of directors and top management will find this study useful in reviewing the strategies to improve the quality of corporate governance of their firms. Finally, the study will provide avenue to further research into the topic of corporate governance and profitability of food and beverages firms in Nigeria.

\subsection{LITERATURE REVIEW}

\subsubsection{Introduction}

Corporate governance and profitability are the twilight zone of a firm. Every corporation has the intention to continue its existence to perpetuity through sustainable profitability. The ability to maintain high profitability of a firm is depending on the robustness of corporate governance in making healthy strategic decisions. Contemporary corporate governance began in 1992 with the Cadbury report in the United Kingdom. It is about what the board of company does and how it sets the values of the company, and it is to be distinguished from the day to day operational management of the company by full - time executives (FRC, 2014). Corporate governance provides the structure and process by which companies are efficiently directed and controlled towards maximizing the wealth creating objective of the firm. SEBI (2003) believes that companies having good corporate governance system in place are rewarded by investors and markets with high valuations. Aggarwal (2013), states that good corporate governance is integral to the very existence of a company. It inspires and strengthens investor's confidence by ensuring firm's commitment to higher growth and profits. Thus, strategic decisions making in regard to firm future profitability will not be effective without good corporate governance practices. Corporate governance practice is the soul of corporate business. Following its importance in improving corporate financial performance, and achieving corporate objectives, corporate governance has also been referred to as: Corporate administration, corporate command, corporate executives, corporate polity, corporate control, corporate direction, corporate guidance, corporate power, corporate law, corporate domination, corporate influence, corporate government, corporate authority, corporate empire, corporate charge, corporate powers-that-be, corporate oversight, corporate supervision, corporate regulation, corporate management, corporate dominion, corporate jurisdiction, corporate handling, corporate rule and corporate policies. On the other hand, profitability provides a microscopic view of the firm's economic wellbeing and the efficiency of the firm's board and management. Profitability thus, is a life wire gauge for evaluating, monitoring managerial and measuring performance of those charged with the responsibility of corporate management, including the overall roles of the board in maintaining the wheel of the entity. Glautier, et al. (2011) see profitability as an index that expresses the gain over the cost involved. The uncertainty attached to the possibility of realizing gains in competitive markets heightens the need for the knowledge of costs and the system of corporate governance practice that may give rise to profitability. There is therefore an overwhelming influence of corporate governance on corporate profitability which suggests that, there is a strong association between corporate governance and the firm profitability. 


\subsubsection{General Perspective of Corporate Governance}

Today, researchers and authors are finding it difficult on the best way to approach the issue of corporate governance ever since it has become a global phenomenon and widely studied. Like most social science concepts, it does not have a universally accepted definition which enjoys consensus of views in all circumstances and environments. This is due to the inherent disparities in firm structural, cultural, social, economic, legal settings of countries as well as the perspectives of the researchers, regulators and practitioners. Accordingly, corporate governance can be viewed from at least two major perspectives: "the narrow and the broad." The narrow perspective in this regard refers to the agency and shareholder value theories of corporate governance, while the broad perspective refers to the stewardship, stakeholder, resource dependency, political and value-synergy theories of corporate governance. In a nutshell, the narrow perspective describes corporate governance primarily as being concerned with ensuring that the firm is run in the best interest of shareholders. The ultimate goal here is to ensure that corporate management practice is geared towards maximizing shareholders value alone. The proponents of this perspective generally define corporate governance as the process by which suppliers of funds exert control over managers in order to ensure that their capital is not only safe from being expropriated, also earn a return on their investment. This perspective of corporate administration suffers the weakness of relegating corporate polity by looking at only one side of the many sided components of a firm. While considering only the relevance and rewards of suppliers of funds, it ignores the vital aspects of governance structure and process that will lead to convergence of managers' and shareholders' interest, among other legitimate groups. On the other hand, the broad perspective sees corporate control primarily as being concerned with ensuring that the firms are run in such a way that corporations' resources are used efficiently in the best interest of all affected groups. The ultimate objective here is to ensure that corporate governance practice is operated towards making contributions to every stakeholder. It has also been debated that the broad perspective suffers from the inability to provide the structures and processes of achieving the meditating role of corporate direction. Based on this view, many authors have defined corporate governance as a mechanism that is concerned with ways in which all parties interested in the firm's well-being attempt to ensure that managers and other insiders take measures that safeguard the interest of the stakeholders. Every other definition of corporate governance takes its precedence from these two perspectives containing the various theories in corporate governance. Cadbury Committee Report (1992) provides a useful definition of corporate governance as "the system by which corporations are directed and controlled" in the interests of shareholders and other stakeholders. The implication of this definition is that companies are directed and controlled from inside and outside the company. Neuberger and Lank (1998) perceived the concept as structure and processes to direct and control corporations and to account for their operations. Even though, the Nigeria national code of corporate governance could not provide any definition for the subject matter, the Central Bank of Nigeria (CBN) in 2014, defines the concept in a similar way International Monetary Funds (IMF) does as the rules, processes, or laws by which institutions are operated, regulated and governed. In Thailand, the National Corporate Governance Committee (NCGC) defines the term as a system having a corporate control structure combining strong leadership and operations monitoring. The Asian Development has defined it as the manner in which authority is exercised in the management of a country's social and economic resources for development. Okereke (2013) and Keasy, et al. (1997), see corporate governance as the set of structures, processes, customs, policies, laws, and institutions affecting the way corporations are directed, administered or controlled as well as the relationships among the many stakeholders involved and the goals for which the corporation is governed. Oyediran (2003) refers corporate governance to the manner in which the power of a corporation is exercised in the management of its total portfolio of socio and economic resources with the aim of increasing shareholders' value and safeguarding the interest of other stakeholders in the context of its corporate mission. Further, it can be described as the process by which persons entrusted with the responsibility of direction and control ensure accountability, transparency and fairness in the identification, measurement, summary, preparation, interpretation and communication of economic events required to determine the performance of the corporation in the interest of all stakeholders. Corporate governance is a system that requires 'intellectual integrity', 'intellectual honesty', 'intellectual competence', 'intellectual behaviour' and 'intellectual leadership' that will generate value - synergy effect to maximize the long-time value of the firm for the benefit of all interest groups. Accordingly, corporate governance is the process that establishes a culture of behaviour in an organization; employs and deploys the requisite resources for planned performance in a manner that will maximize corporate value and improve the wellbeing of all groups without compromising to any party. OECD (2004) defines corporate governance as: "a set of relationships between a company's management, its board, its shareholders and other stakeholders." According to OECD (2004), corporate governance provides the structure through which the objectives of the company are set, and the means of attaining those objectives and monitoring performance are determined. Cadbury (1992) in United Kingdom Commission Report tried to harmonize the various views of corporate governance when he stated that corporate governance is concerned with holding the balance between economic and social goals and between individual and commercial goals. According to Tricker (1994) and Oteh (2013), corporate governance essentially involves balancing the interest of the many groups in a firm - these include its shareholders, management, customers, suppliers, financers, 
government and the community. The governance framework is there to encourage the different use of resources and equally to require accountability for the stewardship of those resources. The aim is to align as nearly as possible the interests of individuals, corporations and society.

\subsubsection{Purposes and Objectives of Corporate Governance}

The primary objective of sound corporate governance is to improve corporate performance and accountability and creating long-term shareholder value by monitoring those parties within a company which control the resources owned by investors. The supporting purposes are to ensure that there is a suitable balance of power on the board of directors; make the board of directors responsible for monitoring and managing risk; ensure the external auditors are independent; to increase level of confidence and transparency in company activities for all investors and thus promote growth; ensure that the company is run in a legal and ethical manner; and build in control at the top that will "cascade" down the organization. The 2012 UK combined code on corporate governance and FRC (2014) note that the purpose of corporate governance is to facilitate effective, entrepreneurial and prudent management that can deliver the long-term success of the company, and to align as nearly as possible the interests of individuals, corporations and society Cadbury (2002). Accordingly, the main purposes of corporate governance include to: ensure that the board, as representatives of shareholders, protects the company's resources and allocates them in a manner to meet the company's goal; ensure that those governing and managing the company properly account to its stakeholders; and ensure that shareholders and other stakeholders can and do hold the board to account for their management and control of the company (Ofo, 2011b; Farreira, 2010; Ajagbe, et al., 2011), and elimination or mitigation of conflicts of interests; and to ensure that the assets of the company are used efficiently and productively in the best interests of its investors and other stakeholders (CFA Institute, 2013). The National Corporate Governance Committee (NCGC) of Thailand provides the purpose of corporate governance is to establish a transparent working environment and enhance the company's competitiveness. According to the report of the SEBI Committee on Corporate Governance (2003), the fundamental objective of corporate governance is to enhance the long-term shareholder value, while at the same time protecting the interests of other stakeholders by improving the corporate performance and accountability. Okereke (2013) and Sharafa (2014) identify objectives and significance of corporate governance to include: to ensure that those responsible for directing and controlling the activities of a company comply with ethical standards and relevant legislation; to restore lack of confidence perceived by the public as regards financial information and reporting; to fight against corruption and promote good labour relationship and safeguard the rights of consumers; to prevent corporate theft and fraud; to ensure sound internal control system. Corporate governance is developed with the primary purpose of promoting a transparent and efficient system that will engender the rule of law and encourage division of responsibility in a professional and objective manner (CBN, 2014).

\subsubsection{Core Attributes of an Effective Corporate Governance System}

Many scholars have attempted to address the question of "what drives the passion for good corporate governance." According to the work of Roberts and Young (2006), the answer is in a theory about corporate behaviour and behind that a set of beliefs about human behaviour. It is important to understand the core qualities required within the frame of corporate governance system in making it effective and reliable. These attributes are by principle required to be binding on all persons that have explicitly consented to this corporate custom. This corporate norm is as such, may not be contained in any specific legal document. But both in principle and practice, "custom floats in the air as it were. It is there, but it is nowhere." So, that which seems to be corporate custom lies in the corporate conscience. Cadbury committee report (1992), points out three key principles of corporate governance to include openness, integrity and accountability. Mervyn King, the Chairman, King Commission Report of 1994, pointed that good corporate governance is about 'intellectual honesty' and not just sticking to rules and regulations. The CFA Institute (2013) identifies five core attributes of an effective corporate governance system to include: rights, responsibilities, accountabilities, fairness and equitability, transparency and accuracy, protection and enforceability, independence and integrity. Aras and Crowther (2008) state that, in practice, there are four principles of good corporate governance, which are: transparency, accountability, responsibility and fairness and ACAG (2010) in Akharayi (2015) added participation and predictability. Corporate governance is about promoting corporate fairness, transparency, accountability and ethical behaviour. Accordingly, the foundation to sound corporate governance is the good action of the individual, which is guided by a person's moral stance. Characteristics which are important in the development of an appropriate moral standard include: fairness, openness, independence, integrity, transparency, accountability, probity, responsibility, reputation and judgement. Kocourek, Burger and Birchard (2003) emphasised that simply legislating changes will not improve corporate governance, unless the directors possess these qualities. In the light of recent corporate governance crises and corporate scandals around the world, there have been calls to pay more attention to the personality and behaviour of company directors and managers (Baker, 2009; Young, 2009; Clarke, 2010; Kirkpatrick, 2009; and OECD, 2009). The inappropriate behaviour of boards of directors was clearly viewed as a major contributory element to the corporate crisis (Okoye, 2012:1). Following the 2008 financial crisis, the United Kingdom constituted Walker Review Committee, which provided recommendations on the requisite behaviour of board members, and the 
findings state that board behaviour cannot be regulated or managed through organizational structures and controls alone. According to Okoye (2012), this is an indication that board members may not be confined to appropriate behaviour merely by the institution of corporate governance structures and processes. It is in this regard that the Walker (2009) UK Review recommended that the assessment of board members should include among others evaluation of behaviour and motivation. In the United Kingdom and United States, even in Nigeria, there has been more focus on corporate governance structures in the recent decades and according to Okoye (2012), it is far less focus on the actual behaviour of the company agents who bring these structures to life. It is in recognition of the need for core personality quality in the board that section 4(4) of the SEC (2011) code of corporate governance provides that the members of the Board should be individuals with upright personal characteristics, relevant core competences and entrepreneurial spirit. Several examples of personality issues have been linked to corporate collapses, and hence White (2013), states that some observers believe that ethically responsible companies design and use governance mechanisms that serve all stakeholders' interests. According to White (2013), importance of maintaining ethical behaviour is seen in the examples of Enron, Arthur Anderson, WorldCom, Health South and Tyco. In recognition of the essence of corporate ethics in developing effective corporate governance, James Joseph, former United States' Ambassador to South Africa said: "Business must harness the power of ethics which is assuming a new level of importance, and power." This power of ethics is wholly required to sustain corporations from collapsing and to keep business entities strong and viable in the course of achieving their objectives and desired performance.

\subsubsection{Importance of Corporate Governance}

From economic history, corporate governance is important in numerous ways: it strengthens the control structure of a business, which "increases accountability of management and maximizes sustainable wealth creation." "Institutional investors believe that better financial performance is achieved through better management, and better managers pay attention to governance, hence the company is more attractive to such investors." Good corporate government may cause the share price to rise - which can be referred to as the 'corporate governance dividend.' Good corporate governance may cause a firm to be socially responsible. A socially responsible company may be more attractive to customers and investors; hence, revenues and share price may rise. Further, it is not until we understand how important corporate governance system is to human welfare, it will continue to sound mundane, even boring. "The material progress and technological breakthrough of the last two centuries, ranging from steam engines, cotton gins, and telegraphs, to automobiles, airplanes, and telephones, to computers, DNA splicing, and cell phones, would not have been possible" without the system of corporate governance in force. Efficiently utilizing the scarce resources of the business to yield high profitability is the system's critical function. Corporate governance is concerned primarily with protecting weak and widely dispersed shareholders against self-interested directors and managers. It is focused on preventing corporate collapses and maximizing profitability objective of the firm. Good corporate governance is also germane to securing investor confidence in any corporation (Ajayi, 2011), and for a firm to grow and develop, its governance process and structures must be well run (Akharayi, 2015). Effective corporate governance can create safeguards against corruption and mismanagement and promote transparency and efficiency in economic affairs. It is at the heart of building confidence in corporate governance system that sustainable profitability occurs. Accordingly, effective corporate "governance structures allow organizations to manage their affairs with proper oversight and accountability, to create value for shareholders through sound investment and innovation, and provide control systems commensurate with the risks involved." Ganiyu and Abiodun (2012) identify corporate governance as a tool for socio-economic development. Good corporate governance will ultimately lead to reduction in the incidence of corporate failures, poor internal control system, poor corporate structure, indiscipline both on the part of management and workers (Ganiyu and Abiodun, 2012). Good corporate governance can enhance investor trust, attract outside investment, and demonstrate a country's commitment to observing international standards (Oteh, 2013). While good corporate governance will ultimately contribute to sustainable economic development by enhancing the performance of companies and increasing their access to global capital, poor corporate governance tends to weaken a company's potential and may lead to financial difficulties and even fraud (Oteh, 2013:19). Poorly governed corporations do not only pose a risk to themselves, they do to others and could indeed pull down capital market Ganiyu and Abiodun (2012). Poor corporate governance was identified as one of the major factors in virtually all known instances of firm's distress in the country (Ajayi, 2009). Oteh (2013), states that capital is attracted by returns as much as good corporate governance and best practice. In other words, if there is a lack of good corporate governance in a market, capital will leave that market (King I Report, 1994; Levitt, 1998; Oteh, 2013). Good corporate governance is a scientific way of generating a competitive and reasonable return on investment for the shareholders.

Evidence suggests that companies with strong governance had greater investment performance. Researchers have shown that improving a company's corporate governance has proportionately greater impact on countries with weak legal environments. Also, they suggested that companies can partially compensate for ineffective laws and enforcement by establishing good corporate governance at the company level and providing credible investor protection. White (2013) posits that effective corporate governance is of interest to nations as it 
reflects societal standards. Accordingly, how nations choose to govern their corporations affects firm's investment decisions; firms seek to invest in nations with national governance standards that are acceptable. Ekineh (2009) contends that "irrespective of how sound macro - economic policies are, if entities are not well governed the macro - economic objectives may not be attained. Recent domestic and global happenings attest to this and have further reinforced the importance of good corporate governance." Levitt (1999) affirmed that corporate governance is 'indispensable to effective market discipline.' Oteh (2013) argued that capital is attracted by returns as much as good corporate governance and best practice. If there is a lack of good corporate governance in a market, capital will leave that market with the click of a mouse. Levitt (2000) succinctly articulated that: "if a country does not have a reputation for strong corporate governance practices, capital will flow elsewhere. If investors are not confident with the level of disclosure, capital will flow elsewhere. If a country opts for lax accounting and reporting standards, capital will flow elsewhere. All enterprises in that country - regardless of how steadfast a particular company's practices may be - suffer the consequences." Norwani, et al, (2011) added that good corporate governance is aimed at enhancing business prosperity and corporate accountability with the ultimate objective of realizing long-term shareholders value. Panfilii and Popa (2012) contend that good corporate governance can remove mistrust between different stakeholders, reduce cost of capital and improve performance, and to prevent earnings manipulation and fraud (Cohen, et al, 2004) and Mervyn King, in King Commission (1994) report added that capital flowed towards companies that practiced this type of good governance and will be conform while it performs.

In their research work, Ganiyu and Abiodun (2012) believe that corporate governance if properly and efficiently put in place can greatly assist the food and beverages sector by infusing better management principle, effective control and accounting systems, stringent monitoring, effective regulatory mechanism and efficient utilization of firm's resources resulting in improved performance. The corporate governance of food and beverages firms in Nigeria is important for several reasons. First, food and beverage sector has an overwhelmingly dominant position in the non - financial systems of Nigeria, and are extremely crucial engines of economic growth, and providing the basic needs of the economy. Second, the sector is one of the most important sources of utilizing the produces from the primary industry and it involves interdisciplinary industry. It links many other sectors of the economy together. Third, the industry is the main use of the finance from local and foreign capital markets thereby helping to enhance the robustness of the capital market activities. Fourth, it provides the source of feeding the nation at large. Given the importance of food and beverages firms, their governance now assumes a central role in increasing profitability. There is a substantial evidence to show the positive correlation between the development of food and beverages sector, economic growth and poverty reduction. The recent increase in the nation's GDP is due to rapid increase in this sector. The Nigerian food and beverages firms therefore have a significant role to play in the development of the country's economy. Effective corporate governance practices are essential to restoring public trust and confidence in the sector. This is as weak corporate governance may contribute to food and beverages firms' failure, lead to a run in the sector and bequeath massive unemployment, cause hardship and starvation, inflation and several other negative impacts on the economy.

\subsubsection{Elements of Corporate Governance}

Corporate governance as a global phenomenon has many universal characteristics. This study concentrated on four board characteristics: size of board of directors, board composition, board skills and competence and board diversity as the independent variables.

\subsubsection{Board Size}

The extant literature has identified size of board of directors as one of the characteristics of corporate governance. Board size refers to the total number of directors on the board of any corporate organization (Dozie, 2003; Ogbechie and Koufopoulos, 2010:6). Determining the ideal board size for an organization is very important because the number and quality of directors in a firm determine and influence the board functioning and corporate profitability (Ogbechie and Koufopoulos, 2010). Dabor, et al. (2015), posit that there is no agreed number of members that make up an ideal board size. According to them, there have been diverging opinions by various investigators on the number of persons that should make up an ideal board size. Tornyeva and Wereko (2012) confirm that the pending issue is on how to determine an optimal board size since companies have different needs and several factors are considered before appointing any person as a director on the board of a company; these factors according to them include issues of the diversity of the company's operations, skills requirement, shareholding structure, regulatory requirements, and size of the company; also, nature, size and complexity of the enterprise as well as its stage of development (Okereke, 2013). In determining board size, Lipton and Lorsch (1992) recommend a number of board members to be between eight and nine. Jensen (1993) argues for seven or eight members; Brown and Caylor (2004) suggested a board size of between 6 and 15 members; Tornyeva and Wereko (2012) support an ideal board size of 7 and 9. Tanko and Kolawole (2007) recommend about 10 to 15 board members for a firm that is averagely large. Section 246(1) of the Companies and Allied Matters Act, CAMA 1990 provides that every registered company shall have at least two (2) directors. However, this section does not take 
cognizance of the minimum number of directors required to register and operate a public liability company, which is presently the focus of corporate governance. Section 4.2 of 2011 SEC code on corporate governance in Nigeria provides that membership of the board should not be less than five (5). While section 5.6 of the exposure draft of 2015 National Code of Corporate Governance increases the minimum number of board size to eight (8). Meanwhile, section 4.1 of the 2011 Code and Section 5.1 of the Exposure Draft of 2015 NCCG in Nigeria emphasize that the Board membership should be of a sufficient size relative to the scale and complexity of the company's operations and such that cannot compromise availability of members to attend meetings. A board of directors should not be too large or too small in number in a way as to distort the company's operating performance. Therefore, board size should be considerable as it influences the overall performance of a firm. Hence, it would be optimal to have a board size of between 7 and 10 members to ensure efficiency of operations, diversity of skills, and improved performance.

Some school of thoughts are of the view that a small board size is more effective because it enhances fast decision making and cannot be manipulated by management (John and Senbet, 1998; Dalton, et al; 1999; Dozie, 2003; Dabor, et al; 2015). According to John and Senbet (1998), large boards are less effective and are easily controlled by the CEO. Further, they argue that when a board gets too big, it becomes difficult to coordinate and for it to process and tackle strategic problems of the organization. Dalton, et al. (1999) posit that a large board is overcrowded and hence does not give room for each member's input; it is also less organized and unable to reach a decisive conclusion on time. Also, Dozie (2003) argues that a smaller board may be less encumbered with bureaucratic problems, more able to provide better financial reporting oversight. Dabor, et al. (2015), identify some of the disadvantages associated with a large board to include high cost of coordination and delay in passing information as well as weak monitoring. Larger board may also serve as a breeding place for incompetent directors to hide and it encourages multiple directorship phenomena. As a result, some of the directors may not be able to justify the huge sum of remunerations they receive. Large board size could also be identified with loss of passion and commitment to service. Ganiyu and Abiodun (2012) have argued that larger board membership could result in difficulty in arriving at a consensus in decision making and this has the tendency of weakening corporate governance effectiveness. According to Tornyeva and Wereko (2012), larger boards may experience agency and free - rider problem. Agency problem increases with board size because of more conflicting groups representing their own diverse interests; also free - riding increases as some directors neglect their monitoring and controlling duties to other directors on the board (Nanka - Brune, 2009:32; Tanko and Kolawole, 2007). Lipton and Lorsch (1992) and Jensen (1993) posit that large boards are less effective and are easier for a CEO to control. According to them, when a board gets too big, it becomes difficult to coordinate and becomes problematic especially in terms of the process involves in decision making and agency cost will increase, thereby reducing the operating efficiency and positive performance of firms. It has further been argued that larger boards have larger financial cost implication since they consume more pecuniary and non - pecuniary company resources in the form of remuneration and perquisites than small boards (Gyakari, 2009:98); and very prone to fictionalizations and coalitions that will delay strategic decision making processes (Forbes and Milliken, 1999). Yermack (1996) has argued that coordination, communication and decision - making problems increasingly impede company performance when the number of directors increases. The empirical studies of Yermack (1996); Eisenberg, et al, (1998); and Mak and Yuanto (2003), Aljifri and Moustafa (2007), support for small board size. In addition, Kyereboah - Coleman and Biekpe (2005) in Tanko and Kolawole (2007) found that small board sizes enhance the performance of firms quoted on the stock exchange. These views however, portray the boards as a burden to the organization rather than as a reservoir of intellectualism, source of capital, and embodiment of skills and diversified managerial experience that its large number is required to maximizing corporate value and improving the wellbeing of all groups. According to Forbes and Milliken (1999), large board size provides an increase pool of expertise because larger boards are likely to have more knowledge and skills at their disposal to make better decisions. They are also capable of reducing the dominance of an overbearing CEO to dominate and hence put the necessary checks and balances. Jensen (1993) points out that board's monitoring and supervising capacity is increased as more and more directors join the board. Further it helps to provide sufficient number of board committees that serve as the thinking tank of the entire boards and facilitates quick and encompassing strategic decision - making process. Large boards could provide the diversity that would help companies to secure critical resources and reduce environmental uncertainties (Pfeffer, 1983; Pearce and Zahra, 1992; Goodstein, et al., 1994). Thus, as an extra member is included in the board, a potential trade - off exists between diversity and coordination (Uadiale, 2010). From resource dependency perspective, Marlin and Geifer (2012) have argued that larger board size may increase the number of external linkages and thus increase the potential for securing needed resources. Borokhovich, et al. (2005) and Miller (2009) affirm that prior research suggests that larger boards may increase monitoring strength as well as reduce the potential for domination by the powerful CEO (Singh and Harianto, 1989). Larger board size facilitates director independence. According to Pearce and Zahra (1992), larger boards provide better access to their firm's external environment, risk reduction and acquisition of critical organizational resources needed for firm performance. This is because the directors are expected to be an important link between the company and 
their networks. Yawson (2006) posits that because of the diversity of the directors of larger boards it enhances the knowledge base of the companies. More so, Berger, et al. (1997) found that companies with larger board membership have low leverage. Accordingly, they assume that larger board size translates into strong pressure from the corporate board to make managers pursue low debt ratio. The preponderance is that with larger board size, there will be lower payment of interest expense resulting to lower operating expense and higher profitability than where the board size is smaller. Uadiale (2010) study reveals that large board size performs effectively and therefore recommends the encouragement of large board size in Nigerian firms to enhance financial performance. Dehaene, et al. (2001) finding shows that large boards should be encouraged. Nonetheless, a further review of the empirical results on the impact of board size on performance show mixed conclusions. The findings of Haniffa, et al. (2006), show inconclusive results of the impact of board size on firm performance.

\subsubsection{Board Composition}

Board composition refers to the number of independent non-executive directors on the board relative to the total number of directors (Uadiale, 2010). It is the proportion of those directors serving on the board who do not hold management positions in the company. Board composition is the ratio of non-executive and independent nonexecutive directors or outside directors to the overall board size. Goergen and Renneboog (2000) refer to it as the distinction between inside and outside directors. According to them, it is traditionally shown as the percentage of outside directors serving on the board. It is important to note that there is no clear conclusion on what should be the optimal board composition. Section 4.1 of 2011 Code of Corporate Governance in Nigeria states that the board should be composed in such a way as to ensure diversity of experience without compromising independence of members, and section 4.3 of the code adds that the board should comprise a mix of executive and non-executive directors, headed by a chairman, who shall be a non-executive director. The majority of board members shall be non-executive directors, at least one of whom should be an independent director. This provision implies that a board of directors should consist of three categories of members: Executive director, non-executive director and independent non-executive director. This means that the larger proportion of the directors serving on the board should be non-executive directors. Considering the minimum requirement of five (5) board members and at least one (1) independent non-executive director in 2011 code, it suggests a board composition of non-executive and independent directors to executive directors - factor of $4: 1$. This indicates that $80 \%$ of the board size should be the maximum of the board composition. The aftermath of the board composition is that there should be a higher number of non-executive directors in the board membership if the corporate governance practice of firms is to be effective and seen as being effective. Further, section 5.4 of the Exposure Draft of 2015 NCCG in Nigeria provides that the number of executive directors on the board should not be more than one-third of the board. Section 5.5 adds that the number of non-executive directors on the board should not be less than two-thirds of the board and the number of independent non-executive directors should not be less than half of the number of non-executive directors. This provides the board composition of non-executive and independent non-executive directors to executive directors - ratio of 7:2. This indicates that $77.78 \%$ of the board size should be the maximum of the board composition. The provision is plausible to conclude that larger number of the directors is expected to be outside directors; making the larger the board, the larger the board composition. In order to realize the benefit of board composition, section 6.6.1 of 2015 of NCCG provides that non-executive directors should be chosen on the basis of their wide experience, specialist knowledge and personal qualities and are expected to bring these qualities to bear on issues of strategy, performance and resources. More so, section 6.6.2 provides that non-executive directors should constructively challenge and contribute to the development of the strategy of the company and satisfy themselves that the financial information provided by the company is accurate and that the company has in place a robust and adequate internal control and risk management systems. Further, John and Senbet (1988) posit that boards of directors are more independent if they have more non-executive directors. As to whether the presence of non-executive directors on the board will relatively impact on the firm's performance, according to Higgs (2003) is largely invisible and poorly understood. According to the studies conducted by Korn/Ferry and Egan (2002; $2005 ; 2005)$, there is an increasing trend to have a majority of non-executive directors on the boards. Their findings suggest that this trend to appoint more non-executive directors than executive directors is a factor of almost $3: 1$. Also in Nigeria, the ratio of non-executive directors to executive directors on the board has increased remarkably since the introduction of 2003 code of corporate governance for public companies in Nigeria by SEC; and this is a factor of almost 4:1. Although, Fama and Jensen (1983); Banysinger and Hoskinsson (1990) and Hermalin and Weisbach (2002) have argued that the effectiveness of a board depends on the optimal mix of inside and outside directors, there is very little theory on the determinant of an optimal board composition. Although inside and outside directors have their respective advantages and disadvantages, there is an apparent presumption that boards with significant outside directors or non-executive directors will make different and perhaps better decision than board dominated by insiders or executive directors. Pablo, et al., (2005) also confirm that many authors favour outside dominated boards. According to Fama and Jensen (1983), independent directors are incentives to scrutinize diligently, because they seek to protect their reputation as effective monitors of managerial discretion. Since they are in a better position to discipline management, independent directors are arguably more effective in prohibiting 
opportunistic behaviour, thereby reducing potential agency conflicts (Bhagat and Black, 2000; Siladi, 2006). Fama and Jensen (1983) and Baysinger and Butler (1985) emphasize that outside directors can increase the element of independence and objectivity in board's strategic decision-making, and also help in providing independent supervision of the company's management, hence making board's oversight function more effective and productive. Scherrer (2003) and Scarborough, et al. (2010) argue that outside directors, in addition to providing valuable access to resources and information, also protect shareholders' interests since they do not have the same concern with their employment or advancement opportunities. Lorsch (1995) and Scarborough, et al. (2010) argue that since the non-executive directors are not involved in the operational activities of company, they would avoid issues of unresolved conflicts of interest and are in a position to look at issues objectively and this would help improve performance. From resource dependence perspective, Hillman, Cannellas and Harris (2002) opine that the resource-dependence role of directors suggests board composition will impact external linkages to the firm's environment. According to Scarborough, et al. (2010), independent boards promote board activism because the directors would be able to challenge and criticise the decisions of the management. These objective criticisms ensure that management is taking the right decisions in the interest of stakeholders which translate into better performance (Tornyeva and Wereko, 2012). Fama (1980) posits that outside may act as 'professional referees to ensure that completion among insiders stimulates actions consistent with shareholder value maximization. Roberts et al. (2005), posit that board effectiveness is related to the degree to which non-executives acting individually and collectively are able to create accountability within the board in relation to both strategy and performance.

However, there are some other theoretical and empirical evidences that are not in support of increase in the board composition of a company. Siladi (2006) points out that a criticism of non-executive directors is that they are too busy with other commitments and are only involved with the company business on a "part-time" basis. It has also been observed that the average director spends only twenty-two days per year on his duties; this is barely enough to perform the essential functions, indeed it may be wandered whether the directors who put in less than average effort can be discharging their duties adequately (Bosch, 1995: 106). Since the average director spends a little more than two weeks a year on the job, it is difficult to develop much more than a rudimentary understanding of their companies' workings (Carter and Lorsch, 2004:45). It has also been argued that inside directors are more familiar with the firm's activities and they can act as monitors to top management if they perceive the opportunity to advance into positions held by incompetent executives. Further, Siladi ((2006) observes that non-executive directors do not necessarily have a "hands - on" approach, or are not necessarily well versed in the business, hence do not necessarily make the best decisions; and argues that "a balanced board" is considered desirable. More so, independent non-executive directors may be operating on the basis of stereotypes and generalization due to they are always coming from outside. They will prefer the outsider's view to the insider; consequently act on stereotypes, generalization, even on unconscious bias. These attitudes will reduce their operational efficiency, strategic actions and obviously decline the firm profitability. According to Tornyeva and Wereko (2012), non-executive directors may not have total commitment to the cause of the company because of other commitments and consequently may not be on top of issues affecting the company and this would limit their contribution to performance of the company. White (2013) has argued that large number of non-executive directors can create problems of limited contact with firm's day-to-day operations and incomplete information about mangers. This will result ineffective assessments of managerial decisions and initiatives. Baysinger and Hoskisson (1990) clearly point that non-executive directors are limited in scope and understanding when it comes to complexities involve in decision making because of their temporal position. It has also been argued that outside dominated boards are merely mechanism to orchestrate agency theory objective of maximizing shareholder value instead of encouraging for a balanced value sharing of stakeholder theory. While many conceptual evidences show that larger proportion of non-executive directors on boards will enhance the firm profitability, however, the findings from some empirical studies are showing mixed and inconclusive results. According to Oluwafemi, et al. (2013), there is overwhelming empirical evidence on the positive role played by outside directors in board's monitoring and control function. Weisbach (1988) conducted a research to know whether monitoring management in company with outsider dominated board is more effective than for companies with insider - dominated board, and found that the composition of the board is what determined the level of monitoring the CEO. Dehaene, et al. (2001), find that the percentage of outside directors is positively related to the performance of Belgian firms. Connelly and Limpaphayon (2004) conclude that board composition has a positive relation with profitability of firms in Thailand. Rosenstein and Wyatt (1990) find a positive stock price reaction at the announcement of the appointment of an additional outside director, implying that the proportion of outside director, affects shareholders' wealth. O'Sullivan (2000) finding from a sample of 402 UK listed companies suggests that non-executive directors encourage more intensive audits as a complement to their own monitoring role while the reduction in agency costs is expected. The study conducted in Nigeria by Uadiale (2010) reveals a positive association between outside directors sitting on the board and corporate financial performance.

In contrast, there is also a fair amount of empirical results that tend not to support this positive relationship between board composition and profitability (Agrawal and Knoeber, 1996; Conyon and Peck, 1998; Ezzamel and 
Watson, 2002; Haniffa and Hudaib, 2006). Some of them report a negative and statistically significant relationship with Tobin's Q (Agrawal and Knoeder, 1996; Yermack, 1996). While some other findings show that the proportion of non-executive directors on the board has no significant impact on the financial performance measures (Vafeas and Theodorou, 1998; Weir, Laing and McKnight, 2002; Haniffa and Hudaib, 2006). In Tanko and Kolawole (2007), Dalton, et al. (1998) study indicates that board composition has a negative correlation with firm performance indicators. Further, based on a large survey of firms with non-executive directors in the Netherlands, Hooghiemstra and Van Manen (2004) conclude that stakeholders are not generally satisfied with the way nonexecutives operate. Haniffa, et al. (2006) identify that high proportion of non-executive directors may engulf the company in excessive monitoring, be harmful to companies as they may stifle strategic actions, lack real independence, and lack the business knowledge to be truly effective. Nonetheless, some other researchers could not reach conclusion of the relationship between board composition and firm profitability (Kanng and Shivdasani, 1995; Kesner, 1987; Dalton, et al, 1998).

\subsubsection{Board Skills and Competence}

Boards require a high degree of specialized knowledge and skills to function effectively. Of the several characteristics evolved for ensuring good corporate governance, the skills and competences of the board of directors remain prominent in developing corporate conscience and core value. Therefore, board skills and competence is one of the pillars for enhancing board effectiveness. It means the ability to conduct board activities for which a director was trained and inducted as prescribed in the code of corporate governance. According to Ogbechie and Koufopoulos (2010), the knowledge and skills most relevant to boards are in two dimensions: functional area knowledge and skills and firm-specific knowledge and skills. According to them, functional area knowledge and skills include accounting, finance, marketing, and law. In addition to these, administration knowledge is necessary. Board members can either possess these skills or have access to external networks that can provide them. In this view, firm-specific knowledge and skills refer to detailed information about the firm and an intimate understanding of its operations and internal management issues. Nonaka (1994) posits that boards often need this kind of 'tacit' knowledge in order to deal effectively with strategic issues. Issues of corporate governance need corporate skills and knowledge to achieve a result. In this regard, if boards are to perform their service tasks effectively, they must be able to combine their knowledge of various functional areas and apply that knowledge properly to firm-specific issues.

A growing interest in board competence is not surprising. In fact, ample evidence of corporate failures strongly suggests a compelling need for it. Failures of corporate entities worldwide have caused organizations to focus a spotlight on boards and the way they carry out their oversight function and prompted a variety of reform and mandates aimed at improving board performance and accountability. Tornyeva and Wereko (2012) have traced several corporate failures to the inability of boards to identify the problems early enough because they lack the requisite skills. According to Coulson -Thomas (2007) if boards are to add more value, make a greater contribution to corporate growth and create a better tomorrow, they may need to challenge conventional thinking and question current practices, and this can only be possible when the board acquired the necessary skills and expertise needed to provide and communicate clear direction, a distinctive vision, compelling purpose, achievable goals and clear objectives. Board is a critical asset for every organization and the need for the governing boards to be informed, engaged, and effective has potentially never been greater; as such, increasing competition for resources, greater complexity and sophistication, and the potential of external regulation drive the need for high quality board members (Brown, 2005).

Despite greater clarity about factors that contribute to better board performance, many firms' directors are often appointed without a clear understanding of the job they are supposed to perform and without receiving any written information about their roles, responsibilities. When boards of directors are not empowered to do their jobs, it is the corporation that will suffer by the way of corporation collapse. Small (2000) notes that many directors are generally asked to serve for their influence or affluence rather than on the basis of predetermined competencies. Consequently, "many boards are made up of very bright, able people whose skills and experience do not match up with the board's needs." In these cases, the board turns out to be a whole that is less than the sum of its parts; as such, the boards should, in fact, be competency - based (small, 2000). According to Okereke (2013), the board having directors with relevant business and industry experience is beneficial to the board as a whole. "Phil Cooke says: 'One of the most damaging sacred cows in organizations is basing employee status on seniority rather than talent. Yes, loyalty is important, but some of the most loyal employees are loyal because of selfishness. They project loyalty to keep their jobs, retain their benefits, or hold on to their authority. Real loyalty is about innovation, original thinking and helping the company to get to the next level." Thus, what underlies the doctrine of corporate opportunity is transparency of directors and top management teams. In their business conduct, they must not only be above board and absolutely loyal to the common cause, they should pride themselves in the quantum of honesty and integrity they exhibit in all their business dealings (Asein, 2014:20). Section 4.4 of 2011 SEC Code of Corporate Governance in Nigeria contains that the members of the board should be individuals with upright personal characteristics, relevant core competences and entrepreneurial spirit. Accordingly, the board of directors 
should have a record of tangible achievement and should be knowledgeable in board matters as well as possess the sense of accountability, integrity and be committed to the task of good corporate governance. However, 2011 SEC corporate governance code and Exposure Draft of 2015 NCCG Code of Corporate Governance could not define the minimum educational qualification, skills, knowledge and experience required as a criterion for membership of board of directors.

\subsubsection{Board Diversity}

For boards to be effective, there is need for diverse perspectives in the board to confront the thinking of management (Ogbechie and Koufopoulos, 1997:8), and hence the demand for board diversity. By board diversity, it means inclusion of persons with different acceptable characters in the board size. According to Vander, Walt and Ingley (2003), diversity in the context of corporate governance is the composition of the board and the combination of the different qualities, characteristics and expertise of the individual members in relation to decision-making and other processes within the board. Decenzo and Robbins (2005) posit that board diversity depicts the varied personal characteristics that make the workforce heterogeneous. It explains the situation where the board composition is made up of individuals with varied skills and disciplines, culture, age, managerial experience, gender, ethnicity and other diverse characteristics that would make the board a complete reservoir of human resources. Coffey and Wang (1998) include functional background, professional experiences, and education; while Forbes and Milliken (1999) added outside board representation and the number of boards in which directors serve (Marlin and Geiger, 2012). The essence of board diversity is to have a complete set of different traits as a "brain bank" of a company. So, board diversity can be referred to as those varied personal characteristics and physical differences in people who are members of the board that make the board heterogeneous (Ogbechie and Koufopoulos, 1997:8). Diversity has been identified as a fundamental governance issue, which has the capacity to influence corporate performance. Society for Corporate Governance Nigeria, SCGN (2014) observes that corporations are increasingly under pressure to ensure diversity within their boardrooms. It has also been argued that many failures in corporate governance practices which in turn contributed to significant low profitability and investor losses were bolstered by the observation that board composition remains highly homogenous and geared towards "group think" and an inability to effectively rein in management and oversee risk. According to Eisenhardt and Bourgeosis (1998); Kosnik (1990) and Kosnik (1990), the promotion of diverse perspectives in a board can generate a wider range of solutions and decision criteria for strategic decisions. When the diversity within the company and its management reflects the diversity within the relevant market, a company is better able to serve and retain that market (Carter, et al. 2013; Pfeffer and Salancik, 1978). Zandstra (2002) asserts that the board should be a group of people who are prepared to speak up and ask difficult questions. They should also be prepared to differ, respect other's views and opinions and talk through them (Kakabadse, et al, 2001; Cutting and Kouzmin, 2002; Dixon and Dogan, 2003). Companies with a higher degree of diversity on the board also give an important signal to potential employees of that company; society regards a higher degree of diversity as positive, and the reputation of the company improves (Luckerath - Rover, 2011). Board diversity is, unsurprisingly, a very hot topic in academic research as well (Ferreira, 2010; Broome, et al, 2011; Dobbin and Jung, 2011). Valsan (2013) opines that, in all advanced societies of today, it is unacceptable to doubt the value of diversity, and rightfully so. Because of the unique characteristics of diversity in corporate governance, a number of countries have introduced legislation imposing gender quotas for boards publicly quoted companies. In Nigeria, for instance, the 2011 SEC Corporate Governance Code recommends that the criteria for the selection of directors shall reflect gender composition. Following the recent demand for gender inclusiveness in boardroom in several countries, this research work focuses the measurement of board diversity only on gender diversity among other characteristics of board diversity. This is because gender is the easiest distinguished demographic characteristic compared with age, nationality, education or cultural backgrounds (Luckerath - Rovers, 2011); the most discussed characteristic of board diversity in recent time and has attracted global attention. More so, the choices of gender diversity was formed on submission to the debate that women directors have a greater "other-orientation" and hence are more committed to the development of stakeholder relationships and the long-term firm value (Langervoort, 2011). Women have unique characteristics and resources needed to to improve the board dynamic, positively influence the strategic direction of a corporation and contribute to the growth of firms (Ijas, 2012; SCGN, 2014). Various writers have therefore suggested that having women in top management can result in higher earnings, greater shareholder wealth and better corporate governance and increased competitiveness (SCGN, 2014). Luckerath-Rovers (2011), opines that the presence of women might improve team performance and reach better decisions; which could ultimately lead to higher business value and business performance (Carter, et al. 2003).

In spite of this, available evidence suggests that women are underrepresented in senior executive and board positions. SCGN (2014) notes that socio-cultural traditions tend to inhibit women from attaining these corporate levels in many parts of African countries, and in recent decades, Board of Directors around the world are overwhelmingly comprised of male gender, and only a small percentage of female directors have emerged despite the extraordinary gains of women in the workplace. Even in Nigeria, it has been observed that Nigerian women are poorly represented in corporate boardrooms. Consequently, companies that fail to draw from the ever 
deepening talent pool of well-educated and high achieving women will fall behind in an increasingly competitive world (SCGN, 2014). In order to achieve the objective of seeing more women recruited to boardroom positions, quoted companies should be required to disclose each year the proportion of women on the board, women in senior executive positions and female employees in the whole organizations (SCGN, 2014). Due to their different values and moral orientation, women are generally more corporate governance-oriented, "which may also influence companies' performance in non-financial areas." It has also been observed that the impact of female board members depends on the nature of the tasks performed. Luckerath-Rovers (2011) results show that firms with women directors perform better than those without women on their boards. As such, Ijas (2012) points that, corporations have been criticised for the low level of female members on their boards.

Gender diversity on the board is supported by different theoretical perspective (Dabor, et al, 2015). Agency theory which is concerned mainly about monitoring role of the boards requires diversified resources from both female and male genders to carry out board strategic direction and control. Representation from diverse groups will provide a balanced board so that no individual or group of individuals can dominate the decisionmaking of the board (Erhardt, et al, 2003). The management may be less able to manipulate a more heterogeneous board to achieve their personal interests at the expense of the firm, and the oversight function may be more effective if there is gender diversity on the board which allows for a broader range of opinions to be considered (Dabor, et $a l, 2015)$. From stakeholder theory, diversity also provides representation of varying interest groups of the firm for equity and fairness (Dabor, et al, 2015). From the stewardship view, the board is an embodiment of responsible, transparent and accountable men and women. In order to reduce conflict of interest, strike a balance between the owners and the management for achieving goal congruence, board diversity is promoted. From the value - synergy approach, boards should comprise of men and women who have regards for each other value, and according to this view, board diversity influences behaviour of employees intrinsically and leaves them with the sense of collective responsibility and belongingness which boosts their impulse for higher commitment and performance. From political theory, the board is a representation of the various social, legal, economic and political environments and these factors make up the society. The society thus admires any organization with board diversity and sees such as being socially responsible organization and with the scent of democratic wing to direct appropriately the affairs of the firm which enjoys from the political tune of the environment. Board diversity in the direction of resource dependency theory sees the board as a source of resources; hence, the resources seem to add better result when they are in the form of heterogeneity. Also, the board is seen as a strategic resource, which provides a connection to different external resources (Walt and Ingley, 2003). Hillman, et al. (2007) investigated how boards of directors serve as a linkage instrument and under which organizational characteristics gender diversity is most valuable. By recruiting female directors, companies may provide these benefits from linking with their stakeholders (Luckerath - Rovers, 2011).

However, Broome, et al. (2011) write that a recent study has shown that, despite showing an almost universal assent to the value of diversity in abstractor, corporate directors and officers have difficulty providing specific concrete examples of instances or ways in which diversity adds value to their boards; some empirical results are mixed and inconclusive (Valsan, 2010). In New Zealand, Bathula (2008) empirical study reveals that gender diversity was positively related with firm performance. Using Dutch listed companies both with and without women on their boards, Luckerath - Rovers (2011) results show that, firms with women directors perform better than those without women on their boards. Erhardt, et al, (2003) empirical research results indicate that board gender diversity has a positive linkage with firm financial performance. In Denmark, Rose (2007) investigation of the impact of female board representation on financial performance of selected quoted Danish companies found that gender diversity does have significant impact on firm financial performance. Empirical evidence shows that gender diversity on boards is not only an ethical obligation, but also seems to have a positive effect on firm performance (Ijas, 2012:2). The study by consultancy firm McKinsey (2007) and Catalyst (2007), a non-profit organization is consistent with the positive relationship of gender diversity and firm performance. Carter, et al. (2003) investigation of relationship between Tobin's Q and the presence of women in the boards of the fortune 1,000 companies found a statistically significant positive relationship. On the other hand, Rose (2007) could not establish any relationship between board diversity and Tobin's Q.

\subsubsection{Other Factors Affecting Profitability of Firms}

Previous studies have shown that having effective corporate governance in place does not always translate into high firm profitability. Suffice it to say that, a firm may demonstrate good corporate governance, but still has low profitability level. The implication is that there may be other factors different from corporate governance characteristics which could influence profitability of firms. Liargovas and Skandalis (2010) confirm that there are still hectic debates about what the best numbers of factors that affect profitability of firms are. Tailab (2014) identifies that several internal factors play an important role directly or indirectly in determining profitability. These other determinants of firm profitability may include: leverage, liquidity, inventory, firm growth, firm age and firm size (in terms of either volume of sales or total assets). However this study could not have accommodated all these factors as control variables. Following availability of data and robustness of the results, firm's size in 
terms of total assets is considered as the control variable of this research work. Firm size could be measured both in terms of total assets and in terms of total sales. It is considered as a fundamental variable that influences firm profitability (Nunes and Serresaueiro, 2008). According to Tailab (2014), despite the fact that the interest of analysing firm size lies in size's effect on profitability, a hectic debate still exists as to whether large companies have more opportunity than small firms to enhance their profitability by taking advantage of economies of scale. In this regard, Goddard, Tavakoli, and Wilson (2005) found that a firm's size had a negative relationship with profitability. A study conducted by Nunes and Serrasqueiro (2008) showed evidence of insignificance relationship between firm size and profitability in large Portuguese firms, while confirmed that in small and medium firms, firm size had a positive and significant correlation with profitability. A study by Okougbo (2011) shows that company size measured on the basis of net book value of assets is found to be positively associated with performance. This suggests that the greater the company size, the greater the firm profitability. Thus, larger firms are most likely to perform better than their competing smaller counterparts because they are open to greater windows of investment and production opportunity. In another development, Lee (2009) confirmed that the rate of profitability had a positive relationship with firm size of United States public companies. Similarly, Omondi and Muturi (2013) found a significant positive correlation between financial performance and firm size of listed companies in Nairobi. These findings were consistent with Babalola (2013), who studied the impact of firm size, both in terms of total assets and in terms of total sales and found that, firm size had a positive influence on profitability.

\subsubsection{Regulatory Framework of Corporate Governance in Nigeria}

Ever since corporate governance 'has become the heart-beat of world economies', almost all the developed countries and the developing economies have enacted one regulatory framework or the other concerning it (Nwonyuku, 2012a). These regulations according to Nwonyuku (2012a) are reflections of global trends emphasizing regulatory compliance and improved disclosure in the wake of significant destruction of shareholders value through a failure to adopt sound corporate governance practices.' Policymakers and regulators alike recognised the need for a body of rules and practices that will reconcile the interests of shareholders, management and the board of directors of corporations following the agency problem that led to continuous collapse of companies. This is considered since regulation is one proven way to provoke behavioural change; governments, policymakers and regulators around the world have devoted significant time and resources to the development of legislation and policies related to corporate governance. According to Ganiyu and Abiodun (2012), poorly governed corporations do not only pose a risk to themselves, they do to others and could indeed pull down capital market. This means, poor governance of a firm would pose a threat to the entire economy. More so, irrespective of how sound macroeconomic policies are if business entities are not well governed, the macro-economic objectives may not be attained (Ganiyu and Abiodun, 2012). OECD (2004) identifies good corporate governance as being capable to contribute growth and financial stability by underpinning market confidence, financial market integrity and economic efficiency. Good corporate governance is feasible through effective regulations and legislations. In Nigeria, the first attempt to provide a code of best practices for public companies was through the Code of Corporate Governance for Public Companies 2003 to supplement the existing legal framework of corporate governance principles, particularly the Companies and Allied Matters Act (CAMA) and the Investment and Securities Act (Ajayi, 2011). And subsequently, other corporate governance codes surface in both industry specific and review of the existing codes in 2011. This made the economy to have multiple codes of corporate governance. It is not until April 2015 that exposure draft for 2015 National Codes of Corporate Governance for private, public and not - for - profit sectors were released. Therefore, the long - standing debate on the needs of corporations to have effective corporate governance mechanisms, which are useful for meeting corporate entity's ultimate objectives and investment decision - making, seems to have reached a defining moment with the publications of codes of corporate governance for publicly listed companies.

\subsubsection{Theories in Corporate Governance}

Corporate governance has been studied by many scholars during the past five decades, which in turn generated some theories and various findings in the area of corporate performance. Among the theories and approaches in corporate governance, only seven of them are discussed in this study. The corporate organizational theories reviewed in this section provide the rationale for the importance of corporate government, and further help to justify the link it has with profitability.

\subsubsection{Agency Theory of Corporate Governance}

Agency theory developed by Jensen and Meckling (1976) is one of the theoretical frameworks underlining the issue of corporate governance. They opined that in agency theory, "shareholder value" is typically identified as the legitimate goal of the corporation, and the purpose of corporate governance here becomes to rectify deviations from this ideal. Accordingly, the definition of problems and the practical corporate governance solutions prescribed by agency theory have proven to be very effective (Hansmann and Kraakman, 2001) as a normative 
blueprint of what constitutes 'good governance' (Fligstein, 1993; Lazonick and O' Sullivan, 2000). According to Olaison, et al. (2013), "optimal" view of the corporation and its governance has with equal vigour and instrumentality been used in the rapid enforcement of governance standards by individual nations as well as international standards setters and will continue to influence future corporate governance regulation. According to Daily, et al. (2003), corporate governance has arguably become dominated by agency theory. Thus, very good number of researchers has confirmed that generally principles of corporate governance are meant to control the internal and external entrenchment practices of executives through internal and external control mechanisms which either align the interest of executives with the shareholders or monitor them directly (Walsh, \& Seward, 1990; Hill \& Snell, 1998; Gibbs, 1993; Boyd 1994). Hillman and Dalziel (2003) identify the main activities of the monitoring function as: monitoring the CEO, monitoring strategy implementation, planning CEO succession and evaluating and rewarding the CEO and top managers of the firm. In this regard, good corporate governance mechanism sets the rule, customs, policies upon which the managers (agents) direct and control the activities of firm towards meeting the interest of shareholders (principals). As applied to corporate governance, the agency theory suggests a fundamental problem for absent or distant owners who employ professional executives to act on their behalf. The root assumption informing this theory is that the agent is likely to be self-interested and opportunistic. According to Roberts and Young (2006), this raises the prospect that the executive, as agent, will serve their own interests rather than those of the owner, principal. This is the agency problem. Basically, the separation of ownership and control brings to the fore the agency problems likely in the forms of "moral hazard", "hidden action", adverse selection or "hidden information", managerial wealth expropriation or self-centred interests of the management at the expense of the shareholders. The agency problems and weak corporate governance, not only lead to poor performance and risky financing patterns, but are also conducive for macroeconomic crises (Claessens and Joseph, 2003). To counteract such agency problems the principal will have to incur "agency costs", costs that arise from the necessity of creating incentives that align the interests of the executive with those of the shareholders and costs incurred by the obligation of monitoring executive conduct to prevent the abuse of owner interests. Agency costs are basically incurred on the role of boards of directors to promote good corporate governance. Boards of directors have fiduciary duties to shareholders to monitor, supervise and control management activities in the company. So, costs associated with agency relationships, and effective governance mechanisms should be employed to improve managerial decision making and strategic effectiveness. Therefore, agency theory as a design for effective corporate governance tends to promote shareholder value through preferment of small board size to large board size, encouragement of large number of non-executive directors serving on the board, board diversity, separation of the office of chairman and CEO, promotion of board skills and competence, among other devices.

Agency theory of corporate governance is a design for neither self-benefit nor fault finding mechanism but a scheme to reinforce such cordial relationship among groups that can influence behaviour for better performance of the firm. Antle (1989) observes that agency models are highly stylized logical tools for discovering basic relationships. They extend the traditional intellectual boundaries of accounting by assuming that its problems have psychological, sociological, economic and political dimensions. According to Glautier, et al. (2011), these problems have been recognized to some extent in articles dealing with the behavioural aspects of performance evaluation. Desai and Yetman (2004) identify cognitive and behavioural limitations as the two areas of agency problems that made human ability to make allocation decision imperfect. According to them, the cognitive limitation is hidden information. This prevents investors from knowing whether the managers allocate resources in the most efficient manner. Also, ICAN (2009) identifies poor information dissemination to shareholders as a problem to effective governance and the main issue on the principal - agency literature is centred on asymmetric information (Oluwafemi, et al, 2013). Glautier, et al. (2011) opine that agency theory addresses the problem of information reporting for assessing managerial behaviour where management holds private information and does not communicate it, or communicates only the information that it wants to communicate. According to Desai and Yetman (2004), the behavioural limitation, which is also known as opportunism, is hidden character. This may circumvent the agents into taking such negative actions that could threaten effective governance.

Agency theory re-examines extant basic assumptions about human behaviour in organizations, by considering behaviour in terms of a model in which protagonists are acting out a principal and agent relationship. The theory considers how to structure the relationship so that the agent acts in the best interests of the principal (Glautier, et al, 2011: 623). However, Davis, et al. (1997); Olaison, et al. (2013), note that despite agency theory appears to be the dominant paradigm underlying most governance research and prescriptions, researchers have suggested theoretical limits of agency theory. Therefore, exclusive reliance upon agency theory is undesirable because the complexities of organizational life are ignored. Ghoshal (2005) finds critiques of its tendency to view subjects as under socialized and without a sense of social responsibility. In the view of Zajac and Westphal (1995), agency theory is seen as creating a self-fulfilling and untestable model: its "actors" come to act in line with the model because the model itself prescribes a dominant rationality; also, that the shareholders wealth maximization model may not work because of the agency problem (Pandey, 2010: 842). The theory sees the principal as possessing self-interest and the agent also as having self-interest; and without reaching goal congruence, the 
organizational performance will suffer. From corporate social responsibilities and business ethics view, Roberts (2003) argues that agency theory imports a narrow view of the corporation and its goals. In legal studies, Bratton (1989) and Ireland (1999) argue that agency theory is charged with obscuring the historical development of corporate forms through its simplified assumptions about the primacy of contractual relations and attributions of ownership. According to Robe (2011), it disregards the moral justification of the corporate form as it stood before the rise of agency theory. Friedman (1953) suggests that the dominance of this prescriptive theory over corporate governance research and practice provides every reason to question both the "is" and the "ought" of corporate governance as an emerging discipline. Notwithstanding its criticisms from the foregoing, it is evident that agency theory considerably extends the debate over the assessment of managerial performance (Glautier, et al, 2011:624). Under the agency theory of corporate governance, the main concern is to develop rules and incentives, based on implicit or explicit contracts, to eliminate or at least, minimize the conflict of interests between owners and managers (Pandey, 2010:842). Accordingly, the firm devises rules and incentives at its own, and there may be in additions to legal regulations in a country.

\subsubsection{Shareholder Value Theory of Corporate Governance}

The shareholder value theory was originally proposed by Milton Friedman. It was first come to prominence with the publication in 1986 of "Creating Shareholder Value" by the United States academic, Alfred Rappaport. It provides that the sole responsibility of a firm is to increase profits. It is an extension of agency theory of firms. While the agency theory focuses on examining the relationship between the agent (manager) and the principal (shareholder), the shareholder value theory centres on the value creation of the managers and the efficiency of the management measured by profitability indices. It suggests that managers should attempt to make as much profits as possible (ICAN, 2009). It is based on the premise that managers are hired as the agents of the owners to run the firm for their benefits, "and therefore they are legally and morally obligated to serve their interests." Accordingly, "the only qualification on the rule to make as much money as possible is "conformity to the basic rules of the society, both those embodied in law and those embodied in ethical custom." It has been argued that "the fundamental goal of all business is to maximize shareholder value." Shareholder value approach considers pursuing profit as the ultimate purpose of the business for its growth, survival and continuity. The idea that management's focus and responsibility is to increase value has gained widespread acceptance. A failure to seek to maximize shareholder value results in pressure from the board of directors and activist shareholders (Wolfer, 2000). It is therefore suggests that the pressure to pursue for shareholder value creation is merely to meet certain leadership interest and owners objectives; rather than being a legalized objective. ICAN (2009) argues that managers tend to purse this objective because of the fact that the ordinary shareholders are, in law, the owners of the organization. They have ultimate control of the company and take residual profits (ICAN, 2009:8). According to Wolfer (2000), the need to prevent takeover movement provided another powerful incentive for managers to focus on creating value. This is because the only compelling takeover defence is to deliver superior shareholder value. Given the globalization of capital markets and their diminishing boundaries, economic systems will slowly run out of capital, if they are unable to create shareholder wealth and thereby attract investors (Wolfer, 2000). Maximizing shareholder value has unquestionably become "the dominant economic creed: with a vast impact on management practice."

The shareholder value theory has the risk that the board of directors appointed by the shareholders might combine force with the management against the firm and the society. Accordingly, executive directors might conspire with the other directors (representative of shareholders) who are interested in short-term gains to extract value from the corporation at the expense of other stakeholders. Denning (2014) identifies the risk that the executives might manipulate the stock price through the use of share buybacks; the directors taking various actions at their disposal so that their personal benefits would be significantly higher than those of the general shareholders. Today, many original owners of corporations have eventually lost out from the ownership control to their agents. The shareholders thus, become the highest losers where corporate governance lost to corporate manipulations, corporate expropriations, lack of adequate control, weak board, and lack of probity, transparency, integrity and accountability (Nwonyuku, 2012a:37). Further Denning (2014) highlights other various risks involved in shareholder value approach to include: the risk of pervasive short-termism; the risk of combines of executives and shareholders; the risk of stock price manipulations; the risk of executive cronyism; the risk of turning talent into vampires (systematically extracting value rather than creating it); the risk of dismantling whole organizations; the risk of losing whole industries; the risk of short-changing customers; the risk of locking in obsolete management practices; the risk of dispiriting employees; the risk of failing to renew human capital; the risk of undermining communities; the risk of killing international competitiveness; the risk of undermining investment and economic growth; the risk of malfeasance becoming endemic; the risk of successive economic crashes; the risk of increasing income inequality; the risk of concentration of economic power; the risk of corrupting society itself. According to Nwonyuku (2012a), the emergence of these fraudulent practices can lead to shareholders value depreciation, depletion, loss of ownership and control and destruction of the entire business empire. Furthermore, ICAN (2009) identifies the deficiencies of this theory to include: a situation where a company, for the purpose of expanding its 
operations, may raise additional capital but the additional profits generated may not justify the additional capital obtained and in this case, profits may be rising but earnings per share may be falling; a company may be earning short-term profits at the expense of long-term profitability; and profit maximization ignores business risk, which is an unavoidable fact of business life as business organizations operate into the future. More so, a common criticism touching shareholder value is often the misunderstanding that a value-based strategy disregards the other stakeholder of the company (Wolfer, 2000) and also negates corporate social responsibility principles. Shareholder value consideration has been attributed with "self-interested management and short sighted focus on current stock price coupled with corporate restructuring and employee layoffs. The problem is that many corporations have driven the concept to an extreme. They have engaged in knee-jerk cost cutting when all slack has already been removed from the system. More so, the inherent dangers involved with the theory historic way of doing business by concentrating solely on the interests of shareholders have its focus on short term strategy and greater risk taking. "The role of shareholder value theory can be seen in the demise of corporations such as Enron and WorldCom where continuous pressure on managers to increase returns to shareholders led them to manipulate the company accounts." Also, Smith (2013) has argued that the mantra that "the CEO and board have a fiduciary duty to maximize shareholder value' is untrue and moreover, the widespread acceptance of that false motion has done considerable harm. According to him, there is no guide prepared for directors of corporations by law firms and other experts that contains a stipulation for directors to maximize shareholder value on the list of things they are supposed to do. It is not a legal requirement. And there is a good reason for that. Smith (2013) broadly stresses that directors and officers have a duty of care and duty of loyalty to the corporation, not to the shareholders in particular. "A director is an agent of company and, as such, is under a fiduciary duty towards the company. He must therefore, act bona fide in the interests of the company" (Adesanya and Oloyede, 1981:235). From another dimension, Smith (2013) argues that shareholders are the equity owners and equity is a residual claim from corporations. Equity holders are at the bottom of obligation chain. Boards of Directors do not have a legal foundation to give them preference over other parties or stakeholders that legitimately have stronger economic interests in the company than shareholders do. According to him, the idea of "the last shall come first" thinking was established in 1976 by the economists Michael Jensen and William Meckling of Harvard Business Review. Amusingly, board members themselves promote the "maximize shareholder value" canard. In other words, this idea did not come out of legal analysis, changes in regulation, or court decisions. It was simply an academic theory that went mainstream - Agency theory. Thus, the implications of Jensen's Agency theory of pushing companies to favour shareholders, when they actually stand at the back from a legal perspective is poor treatment of employees, fraud, tax avoidance, weaken regulation, forge financial reports, making indecent returns, ineffective corporate governance system, high labour turnover, low wage pay and low employee welfare, financial crises and boards complacency.

\subsubsection{Stewardship Theory in Corporate Governance}

'Contrary to agency theory's pessimistic assumptions about the self-interested and self-serving motives of executives, stewardship theory suggests the potential for what it calls the "pro-organizational" motives of directors.' Roberts and Young (2006) argue that the key contribution of stewardship theory lies in its questioning of agency theory's pessimistic assumptions about human nature. According to them, what drives performance here is not the aligned greed of an executive but their personal identification with the aims and purposes of the organization. The idea of stewardship theory came from the work of Donaldson and Davis (1991). The theory is based on the assumption that the interest of shareholders and the interest of management are aligned therefore management is motivated to take decisions that would maximize performance and total value of the company (Tornyeva and Wereko, 2012). Unlike agency theory, stewardship theory assumes that managers are stewards whose behaviours are aligned with the objectives of their shareholders. The theory assumes that managers, left on their own, will indeed act as responsible stewards of the assets they control. Davis, et al. (1997), see stewardship theory as psychological and sociological approaches to governance. The stewardship theory argues and looks at a different form of motivation for agents drawn from organizational theory. The concepts of stewardship attempt to resolve the conflict of interest between the shareholders and managers to a certain extent and in doing so promote goal congruence. In this theory, managers are viewed as loyal, discipline and honest to the company and interested in achieving high performance. The dominant motive which directs managers to accomplish their job, is their desire to perform excellently. It reinvigorates the relationship between the principal and agents by looking at it from opposite angle to that of the agency theory. According to Donaldson and Davis (1991), stewardship theory believes the board of Directors as a group of top corporate players will maximize the firm performance, rather than their individual interest, to increase the wealth of shareholders. Htay, et al. (2013), posit that, since the goal of stewards is to maximize the shareholders' wealth through firm performance, it promotes the goal congruence between shareholders and top management. Specifically, "managers are conceived as being motivated by a need to achieve, to gain intrinsic satisfaction through successfully performing inherently challenging work, to exercise responsibility and authority, and thereby to gain recognition from peers and bosses." According to Tornyeva and Wereko (2012), the stewardship theory believes that there is greater utility in cooperative than individualistic 
behaviour and hence whilst the actions of management would be maximizing shareholder wealth, it would at the same time be meeting their personal needs. This helps to reduce self- centeredness of either of the party and tends to reduce agency problem while promoting good corporate governance practice that will ensure improved profitability. According to Pandey (2010), managers are assumed to work efficiently and honestly in the interests of company and owners and they are self-directed and are motivated by high achievements and responsibility in discharging their duties.

In this theory, managers are seen to be more persuaded to achieve result by intrinsic motivational force. Pandey (2010) believes that managers in this theory, are goal - oriented and self - motivated and feel constrained if they are controlled by outside directors. Based on this, the theory argues that an organization requires a governance structure that allows "harmonization to be achieved most efficiently between managers and owners." In the context of firm's leadership structure, "this situation is attained more readily if the CEO is also the chairman of the board. This leadership structure will assist them to attain superior performance to the extent that the CEO exercises complete authority over the corporation and that their role is unambiguous and unchallenged." Suffice this to say that, based on the stewardship theory, it can be derived that it is not necessary to control the top management since they are the stewards to act in the best interests of the shareholders through firm performance (Htay, et al., 2013). As a result, they prefer the combined board leadership structure of CEO and board chairperson duality to ensure that the firms are under operating in one direction and to get more commitment from the top leaders (Wan, Wan, and Idris, 2012). In this situation, "power and authority are concentrated in a single person," "the expectations about corporate leadership will be clearer and more consistent both for subordinate managers and for other members of the corporate board". As a result, there will be "no room for uncertainty as to who has authority or responsibility over a particular matter;" and "the organization will enjoy the benefits of unity of direction and strong command and control." More so, the theory refutes the assumption that board aims and motives are opposed to those of the shareholders. It insists that both the agent and the principal have an interest in maximizing the long-term stewardship of a company. Stewardship theory requires directors to be accountable to owners for the resources entrusted to them. This theory represents a consensus perspective which rejects the notion that the board of directors is a disciplining mechanism to align conflict of interest between shareholders and managers (Dabor, et al. 2015). According to Davis, et al. (1997), the managers protect and maximize shareholders wealth through firm performance, because by so doing, their utility functions are maximized. To achieve this goal congruent, the shareholders must put in place appropriate empowering governance structure and mechanisms, information and authority to facilitate the autonomy of management to take decisions that would maximize their utility as they achieve organizational rather than self-serving objectives (Davis, et al. (1997). For CEOs who are stewards, Donaldson and Davis (1991) posit that their pro-organizational actions are best facilitated when the corporate governance structures give them high authority and discretion. Therefore, stewardship theory suggests the potentially negative impact of a separation of responsibilities between a chairman and CEO. The roles, as it suggests, should remain combined in order to protect a key aspect of high performance; the strength and authority of executive leadership. It follows the debate that it is not the leadership structure, but the potentials and attributes of the leadership determine the performance of the firm. Davis, et al. (1997) identified five components of the management philosophy of stewardship as trust, open communication, empowerment, long-term orientation and performance enhancement. To bring these attributes to the boardroom, an organization must be ready to appoint a sizeable number of executive directors with wide range of diversity and skills as well as independence of mind. The firm must be willing to put in place such corporate policy that will encourage training and development, accountability, transparency, equal opportunity to all persons and effective information flow. However, Htay, et al. (2013), posit that the agency theory and stewardship theory are developed based on the perception that directors are opportunists. Accordingly, in the stewardship theory, directors believe that the success of the firms will bring them to be impressed by the market and it will bring for their betterment (Htay, et al, 2013). Also, stewardship model has both insider and outsider attributes. According to Garcia, et al. (2008), this approach is more difficult to classify purely as stakeholder or shareholder. Notwithstanding, it has the combination of most elements of the stakeholder model.

\subsubsection{Stakeholder Theory in Corporate Governance}

The idea of stakeholder theory was originally developed by Edward Freeman through his publication in 1984. It is the extension of the responsibility of top corporate players from the shareholder focus to other stakeholders (Htay, et al. 2013). Stakeholder theory challenges agency assumptions about the primacy of shareholder interest. Instead, it argues that a company should be managed in the best interests of all its stakeholders. These interests include not only those of the shareholder but also a wide range of other direct and indirect interests. From agency theory and shareholder value perspectives, the managers have the sole objective of maximizing the wealth of shareholders. Stakeholder theory considers this view to be too myopic, narrow, one-sided and unbalanced interest, particularly, since the actions of the managers can have effect on other interested groups than just shareholders. In order to address this gap, Freeman (1984) developed the stakeholder theory with emphasis on the need for managers to have corporate accountability to stakeholders instead of shareholders. Freeman (1984) defines 
stakeholders as "any group or individual that can affect or is affected by the achievement of a corporation's purpose." Stakeholders have also been defined as "those groups without whose support the organization would cease to exist" (Freeman, 1984: 31). According to Donaldson and Preston (1995), stakeholders are the identifiable groups or persons who have legitimate interest in an organization and these interests have intrinsic value. Stakeholders are all legitimate parties to an organization which ensure that the needed resources for meeting the ultimate objectives of the enterprises are constantly flowing to the desired direction in the best interest of the overall groups. It is on this premise that the concept of collective responsibility is anchored. It sees every legitimate party to the business as an integral part of the business; such that an injury to a party is an injury to all; and an injury to the business is an injury to all. Thus, the theory believes that the firm performance is a general concern; and not to a specific group.

According to Donaldson and Preston (1995) stakeholders are identified through the actual or potential harms and benefits that they experience or anticipate experiencing as a result of firm's actions or inactions. The stakeholder theory holds that companies are accountable for their stewardship over the resources entrusted to them by a coalition of various stakeholders (Dabor, et al. 2015). Ever since stakeholder theory was developed, corporate governance perspective has been taken from a narrow view to a broad view. Htay, et al, (2013), point that stakeholder theory seems to be the combination of a few philosophical ideas from economics, ethics, law and organizational aspects. It is a management theory. The theory seems to give attention on business morality in addition to the maximization of the profit (Htay, 2012). The concept of this theory has currently been adopted by some of the corporate governance guidelines (Htay, et al, 2013), and in Nigeria, 2011 and 2015 codes of corporate governance give credence to it by extending the responsibility of the directors to other stakeholder. Section 28 of 2011 code of corporate governance encourages for more relationship with other stakeholders. Section 4.2 confirms the paramount responsibility of the board is to ensure the positive performance of the company in creating value for all its stakeholders. The corporate governance efforts are intended to empower those stakeholders who contribute or control critical resources and skills and to ensure that the interests of these stakeholders are aligned with that of shareholders (Pandey, 2010). Cadbury (2002) pointed that "corporate governance is concerned with holding the balance between economic and social goals and between individual and communal goal and the aim is to align as nearly as possible the interests of individuals, corporations and society." Cadbury (1992) might have keenly understood that incessant corporate collapses is as a result of heavy push to protect only the interest of shareholders without having on board the interest of other related individuals and society. Stakeholder perspective thus tries to strike a balance between designing a governance structure that would meet the objective of shareholders, and while meeting the needs of the other legitimate groups. The stakeholder theory is based on the premise that the fundamental responsibility of managers is to maximize the total wealth of all stakeholders of the firm, rather than only the shareholders' wealth (Pandey, 2010: 842-843). The global corporate governance crisis has further reinforced the message that governance of firms should always aim at protecting the interests of all stakeholders.

Further, Erhardt, et al. (2003), argue that the theory reveals the function of the board of directors in the theory creation of utilities thus allowing other variables of production to earn their rewards. The stakeholders view considers that investors, employees, suppliers, customers, creditors, debt financiers, auditors, corporate regulators, society and other stakeholders all generally contribute to the firm performance and should in return receive benefits from the firm. According to Okereke (2013), stakeholder value will only be enhanced when a company treats its employees well, serves its customers well, maintains good relationship with suppliers, and has a reputation for civic responsibility and legal compliance. Donaldson and Preston (1995) clearly point out that the stakeholder theory is focused on how management decision making affects all the stakeholders and no one interest group should be able to dominate the others. According to Tornyeva and Wereko (2012), the theory also proposed for the inclusion of the different legitimate interest groups in the organization's board in order to ensure consensus building and to avoid conflicts of interest. This is in addition to the positions of stewardship and resource dependency theories. In order to achieve this purpose, the boards of directors in the stakeholder theory adds to their functions to serve as arbitrators where conflict of interests may arise among the various stakeholders and to ensure effective communication and information system to all stakeholders in an accurate and timely manner. Donaldson and Preston (1995) confirm this when they assert that the board serves as arbitration over the conflicting interests of the stakeholders and brings about cohesion needed for the achievement of the organizational objectives. Jensen (2001) notes that this situation has given managers the discretionary powers to decide on whose interest to serve. In order not to lose sight, Jensen (2001) suggested that managers should pursue objectives that would lead to increasing the long-term value of the firm since this would not be attained by ignoring the interest of some of the stakeholders. Pursuing the long-term value of the firm still will not make the managers to be unfair since every other stakeholder will remain to benefit from such value, but the employee benefit will expire on the virtue of age, length of service, or through other means that will bring such employee's exit from the firm. The implication is that the employee is still being short-changed at the long run.

In relation to company performance, Roberts and Young (2006) assert that stakeholder theory has aided 
in curtailing high executive pay which has negatively affected the level of operating income as well as the level of firm's profitability. Accordingly, excessive levels of executive pay and the way that these have often gone alongside with company downsizing scheme and all its negative impacts on employees and local communities undermine the legitimacy of the demand for "shareholder value". Further, the importance that is now given to corporate value statements, as well as the board's role in creating corporate ethics codes, and social and environmental reporting all reflect an acknowledgement of a wider set of corporate obligations beyond the delivery of shareholder value (Roberts and Young 2006). More so, following this theory, firm's objective is not only limited to creating shareholder's value, also to maximize the welfare or the need of other legitimate interest groups. This could be in the form of improving quality product; product price efficiency; providing corporate social responsibility; timely and accurate payment of taxes; promoting environmental and social friendliness; promoting employee welfare and training and development scheme; facilitating technological innovation; promoting research and development; improving financial reporting quality, among others. These benefits hopefully might have warranted Lashgari (2004) to describe corporate governance as being concerned with managing the relationship among various corporate stakeholders.

However, Roberts and Young (2006), identify the major limitation of stakeholder theory is its complexity "to operationalize because of the difficulties of deciding what weight should be given to different stakeholders interests." According to Roberts and Young (2006), it is argued in terms of corporate governance that if executives were to be made accountable to all of a company's stakeholders they would be answerable to none. Similarly, Tornyeva and Wereko (2012), note that this theory has been criticised for putting too much burden on managers by making them accountable to many stakeholders without specific guidelines for solving problems resulting from conflicting interests. The boards find it difficult to offer optimal service to any given stakeholder. As a result, different stakeholders see the board as bias and not independent in their actions. In another development, Sternberg (1996) disagrees that publicly traded corporations should be "responsive to the rights and wishes of stakeholders" as proposed by Demb and Neubauer (1992). According to Sternberg (1996), "stakeholder theory is both misguided and mistaken," and that "stakeholder theory accountability is unjustified," it "undermines private property, agency and wealth," it "is incompatible with business" and "with corporate governance". This theory has also been criticized for adopting a single-valued objective (Jensen, 2001). According to Jensen (2001), the performance of an organization is not only measured by returns to the stakeholders but equally important is the management of information in the organization with particular reference to vertical communication inter-personal relationships in the organization and the working environment. As a result of the complex nature of the stakeholder relationship and the need for the better management of the different interest groups, Donaldson and Preston (1995) have contended that stakeholder theory should not be a single theory, as such classified it into three different approaches of descriptive, instrumental and normative.

\subsubsection{Resource Dependency Theory of Corporate Governance}

The resource dependency theory was originally proposed by Pfeffer in 1973 and later developed by the work of Pfeffer and Salancik in 1978. The basic proposition of resource dependence theory is the need for environmental linkages between the firm and outside resources. Resource dependency theory is the study of how the external resources of organizations affect the behaviour of the organization. The theory is based on procurement of external resource for the growth and survival of an organization. The procurement of external resources is an important tenet of both the strategic and tactical management of any company. The board is thus seen as a source of resources that can be procured. Boards of directors serve to connect the firm with external factors by co-opting the resources needed to survive (Pfeffer and Salancik, 1978). According to Roberts and Young (2006), seeing the board as a source of resources for a company opens up a very different way to think about the board's role in creating high performance. Accordingly, when an organization appoints an individual to a board, it expects the individual will come to support the organization, will concern himself with its problems, will variably present it to others, and will try to aid it (Pfeffer and Salancik, 1978:173). While agency theory sees the role of boards of directors as primarily monitoring and policing, the resource dependency theory sees their role as basically provision of resources - capital and managerial experience. Unlike agency theory, their original ideas were inductively derived from empirical studies (Roberts and Young, 2006).

Hillman, et al. (2000), identify the various forms of resources directors bring to the company to include information, skills, access to key constituents such as suppliers, buyers, public policy makers, social groups as well as legitimacy. Further, Hilman and Dalzied (2003), provide that resources can take a variety of forms each of which can be argued to add to the "capital" of a company. According to Gkliatis (2009), board capital has been positively associated with the provision of advice and counsel, the provision of firm legitimacy and reputation, the provision of channels of communication and the acquirement of resources elements outside the firm (financial capital influence and influence with political bodies or other important stakeholder groups). According to Johannisson and Huse (2000), the boards of directors perform these functions through social and professional networking. They also use their goodwill and reputational embraces to draw market, financial and economic wheels towards improving firm performance. 
The implications of resource dependence theory revolve round "the optimal divisional structure of organizations, recruitment of board members and employees, production strategies, contract structure, external organizational links, and many other aspects of organizational strategy." According to Roberts and Young (2006), their key contribution is the constitution of the non - executive element of a board, can provide the firm with a vital set of resources. Further, Roberts and Young (2006) opine that non-executive directors can be a source of skills and expertise that an organization cannot afford to employ full time, but which executives can draw upon, both the form of specific skills as well as advice and counsel in relation to strategy and its implementation. They can also serve as an important source of contacts, information and relationships that allow executives to better manage some of the uncertainties in the environment. Accordingly, the value of the non - executive lies not only in their expertise but also through their networks that give the company really access to new markets or to sources of finance, as well as in the reputation benefits that arise from individual's association with the company. This follows that non - executives are greatly appreciated than their inside directors counterparts because of their ability to provide the organization with board capital and board motivation (Okougbo, 2011:36). It is in this regard that board capital and board motivation have been explained as: providing legitimacy, bolstering the public image of the company, providing expertise, administering advice and counsel, linking the company to important stakeholders or other important entities, facilitating access to resources such as capital, building external relations, diffusing innovation and creativity, and assisting in the formulation of firm strategy (Gkliatis, 2009:2).

The resource dependence theory according to Pfeffer and Salancik (1978) highlights the interdependence between organizations and their environment. According to Hillman, Schropshire, and Cannella (2007), this suggests that firms are not self- sufficient and rely on the external environment for survival. In this regard, board composition provides the opportunity for better performance of the firm since it creates the required linkages of the company with external resources. Johnson, et al. (1996), state that firms have to create links with the external environment and board members can serve as one of those links. Thus, the resource - dependence role of directors according to Hillman, Cannellas, and Harris (2002) suggest board composition will impact external linkages to the firm's environment. Marlin and Geiger (2012) are of the opinion that larger board size may increase the number of external linkages and thus increase the potential for securing needed resources. Following the resource dependence theory, it could be logically in order to say that the larger the size of the directors on the boards, the better the performance of the firms since the boards are seen as reservoirs of resources keenly needed for greater corporate performance. Dalton, et al. (1999); Booth and Deli (1996); Booth and Deli (1996); Provan (1980) also believe that the theory favours larger boards. Also, having considered the essence of diversity in deriving greater resources to pilot the organizations, it will also be in agreement to hold that permitting larger proportion of gender on the boards of directors will thus enhance the linkage to achieve efficiency of operation and improve strategic decision making of the boards. Zahra and Pearce (1989) also believe that the diverse background of the directors enhance the quality of their advice, counselling, information and legitimacy. In a similar direction, it is also in agreement that by increasing board skills and competence as one of the resources required of the board to drive other resources, corporate performance will be stimulated.

\subsubsection{Political Theory of Corporate Governance}

Over the last decades, the government of a country has been seen to have a strong political influence on firms (Yusoff and Alhaji, 2012). As a result, there is an entrance of political wheel into the governance structure of firms' mechanism (Hawley and Williams, 1996). The foundation of political perspective of corporate governance was laid by Mark J. Roe in the 1990s and in his subsequent publications over the years brought the development of this nascent theory to fore. The political theory is of the view that the initial and subsisting act upon which the development of corporate governance system is based on the political choice of a nation. What a country does with its legal tradition and system turns on politics: the rules that determine the extent of economic competition within and between countries; the laws and decrees that structure banking, corporate finance, and the securities industry; the rules that shape the markets for capital and labour; and the degree of state involvement in the economy are all political framework. According to Roe (2003), Politics dominates explanations about corporate governance system. Yet, politics which ought to have dominated in the matters of corporate governance is neglected by the various theorists in corporate governance. The theory challenges the other leading interpretations that stress the primacy, and autonomy of corporate governance. The theory opens wider the door of exploration of political influences on corporate law and behaviour (Gourevitch, 2003). Accordingly, it helps to evaluate the status of politics in interpretations of corporate governance and to examine the different meanings that can be given to political explanations as well as provides an important opportunity to examine the status of politics in the conflicting interpretations of corporate governance (Gourevitch, 2003). This is as no one really doubts that politics has something to do with corporate governance, but theorists vary considerably in the status they give to politics in a casual model (Gourevitch, 2003). For Instance, Roe (1994) provides that the American corporate governance system emerged as a result of both economic evolution and its democratic philosophy.

Corporate governance structure of a business enterprise relates to formal and informal contractual agreements among corporate stakeholders (Lashgari, 2004). Charreaux (2004) believes the state to be an essential 
link for political direction of a business enterprise. This is because every emerging firm is as a result of existing political framework put in force by the governance structure. Such firm can as well be weakened by the same political caravan that shot it up. From the foregoing discussion of the nature of externalities and the role of government in resolving corporate governance issues, it is apparent that effective corporate governance is inconclusive without laying emphasis on the role of state in the formation and reforming the governance system. As such, whatever the formal specifications of corporate law, politics shapes daily the calculations made by all players (Roe, 2003). According to Roe (2003), corporate governance arrangements inside the firm interact deeply with a nation's politics. Political forces - party systems, political institutions, political orientations of governments and coalitions, ideologies, and interest groups - are the primary determinates of the degree of shareholder diffusion and the relationships among managers, owners, workers, and other stakeholders of the firm (Roe, 2003).

Gomez and Korine (2011) point that the role of a state within this framework is to constantly re-question entrepreneurial power so as to maintain acceptable limits for individual freedom. This it does through two mechanisms: the market, which creates rivalry between firms, and democracy, which legitimizes power by splintering it. Gomez and Korine (2011) argue that a corporate governance model based only on the calculations of individual interests does not maximize economic performance for society, and that market-self regulation is inadequate. Thus, political theory of governance seems to regulate markets to ensure the convergence of both public and private interests. It brings coherence between protection of investors, employees and competitive character of the goods and services markets (Charreaux, 2004). It centres on the political economy of corporate governance. According to Pandey (2010), the political theory states that it is the government that decides the allocation of control, rights, responsibility, profit, among others, between owners, managers, employees and other stakeholders. Within the overall macro-structure, each stakeholder may try to enhance its bargaining power to negotiate higher allocation in its favour. The corporate governance efforts will, thus, depend on the allocated powers of the stakeholders (Pandey, 2010: 843).

While other theories in corporate governance focus effective corporate governance in terms of economic performance, the political theory has its focus on philosophical, political and historical analyses. In doing so, it identifies a common logic that links both the democratization of corporate governance and the growth of economic performance. According to Gomez and Korine (2011), the theory demonstrates a pattern of change that reflects a tendential democratization of corporate governance. Political theory of corporate governance is underpinned to the fact that the firm is first and foremost a political organization, incontestably the single most important driver in today's societies (Gomez and Korine, 2011). It provides the democratization process that ensures fairness, transparency and accountability of the board. It helps to facilitate participation of all stakeholders - minority shareholders, majority shareholders, employees, government, and regulators through a democratic process. It creates room for all stakeholders to exercise their rights as provided by the political structure (government) through Companies Act, Code of Best Practices, NSE Listing requirements, and other regulatory provisions created out of political system to ensure smooth running of organizations. Thus, political nature of corporate governance puts emphasis on the protective role of the state over the existing firm's property. It assumes that corporate governance must increasingly become more democratic to be seen as legitimate. According to Yusoff and Alhaji (2012), political theory brings the approach of developing voting support from shareholders, rather by purchasing voting power. Accordingly, having a political influence in corporate governance may direct corporate governance within the organization. According to Charreaux (2004), political theory creates productive efficiency through protection of shareholders' interests and reduction of costs of opportunism but not those of management errors. According to Roe (2003), political forces account for the difference in choice of corporate governance modes among advanced industrial countries. In social democracies that support interest of employees, the managers have less incentive to perform their managerial duties in the best interest of the shareholders. Roe (2003) argues where social democracy is strong, shareholder rights are weak, and shareholder diffusion is low. Social democracy gives voice to claims on the firm in addition to those of the shareholders: employee job securities, income distribution, etc.

The theory points how political states will fit into the economic world on a base beneficial to both. According to Yusoff and Alhaji (2012), the political model highlights the allocation of corporate power, profits and privileges that are determined via the governments' favour, and it can have an immense influence on governance developments. Political theory has also been referred to as public system. In Pound (1983) assertion, public interest is much reserved as the government participates in corporate decision making, taking into consideration cultural challenges. It has been argued that this theory is crucial to "rescue corporate governance from its ideologies and failures, restoring concern with governance where it belongs - as centrally located in classical political questions, by reconnecting issues of the political legitimacy of power in the corporation, the historical evolution of corporate governance forms, with questions of economic performance." This is to say, the success of a corporation is a reflection of the success of political structure from where it emerged. Corporate governance system is thus a resemblance of the political thought of a nation. As a matter of fact, the political instrument in which the ideal of good corporate governance is braced ought to be partaker of its shaping and should as well decide the way and form the allocation of the resources should be made for the betterment of the entire 
society. This will help to reintegrate the firms fairly into political-economy structure of the state, by ensuring that every stakeholder is better off just as the firm gets better.

However, the political theory has also been criticized of providing incomplete account as it neglects political preferences and interest group model that cut across the class divide (Gourievitch, 2003). Some authors have argued that while there is the recognition of the fact that politics matters in corporate governance system, but it does not appear to have a substantive theory of politics. Some authors are of the view that the argument of political theory is based on the excessive regulations, "the political constraints rendering firm less than optimal." It is also argued that the political influence of corporate governance is as a result of the state moves to meet its obligatory and optional functions to the country. These functions are already being paid for by the members of the state through a compulsory tax and levies imposed upon the citizens. Therefore, the political influence on the corporate governance needs not to be overblown as such impact is normal. The political perspective also needs to understand that the presence of politics in the corporate governance system is to aid the state attains its national economic objectives consequently; political effect needs not to contest as a theory of its own.

\subsubsection{Value-synergy Approach to Corporate Governance}

Value-synergy approach is developed on the foundation of stakeholder's theory and following the need to simplify the complexity of stakeholder perspective into some specific approaches. Value-synergy approach is on the personnel - employee of the firm. It is intended to encourage self - control and social control through intrinsic motivation, ethics and morality. In the very core of the value-synergy dwells the fact that an organization is an idea that comprises of diverse individuals with different embodiment of resources. That an organization from its set-up is in anticipation that some persons must surely come together to make its purpose come true. And that, the individuals are selected on the basis of the resources they are endowed with; and which the organization must utilize if it is to keep its vision alive. These different individuals bring on board their physical wealth, while some others are with their intellectual or mental capital; all merged together for the purpose of deriving the long - term value of the firm. It is not only the incorporators that can make the designated objectives of firms to be attained. All human factors' efforts are of equal important in this regard. Employees offer their intellectual and physical prosperity while investors or incorporators offer physical or material treasure; making both as co-owners of the idea to make the organization flourish. As a matter of fact, the employees should be given an equal and unique place just as the investors in the value-chain. Employers should be considered as integral owners of the firm hence, should be showered with good human relations. The value-synergy proposal seeks the need to formally recognize employees as a direct stakeholder in the organization and as a key participant in the corporate process, rather than being depicted as a mere factor of production and a commodity traded in the labour market that can be hired and fired at a choice. This new view of employees is an important element in a transition to a more balanced governance structure. Thus, by applying good human relations, the required resources of individuals can be harnessed to improve performance as well as be protected. According to Roberts and Young (2006), the employee is obviously a key stakeholder and there have been long - running debates amongst governance academics that, employees just as shareholders are "residual risk-takers" in a firm. According to Roberts and Young (2006), an employee's investment in firm - specific skills means that they too should have a voice in the governance of the firm. Tipgos and Keefe (2004) point that at the core of restructuring corporate governance is empowerment at all levels shareholders, the board, top management and the employees - consistent with the concept of empowered or reengineered organizations. The goals and objectives of the corporation will be a shared vision.

This value-synergy approach is based on the wish of the employee to be identified, recognized, treat with respect, esteem and value and included into the organization leadership structure as part of the reward for intellectual commitment. This yields sense of belonging, socially desirable and admiration of love which builds passion, commitment and greater focus to face any work challenge and to be more innovative and result-oriented leading to higher performance. The individual feels satisfied when the asset he brings on board is given recognition, value, respect, and cooperation. The value-synergy approach adopts three distinct needs or motives that can motivate people's behaviour to perform in McClelland's Achievement theory. According to Nwonyuku (2015a), they are the need for achievement, the need for power, and the need for affiliation. The Achievement theory is of the view that the needs or motives for recognition and seeking to avoid humiliation for pain are innate and not learned. When human relationship is bashed, inequity will result.

According to Nwonyuku (2015c), a firm objective that seeks to maximize the welfare of all its legitimate groups will create long - term success for the firm. This success creation can be accelerated and sustained by the firm in a most possible manner where all the legitimate groups are seen and made to be seen as value creation. On this premise, the value-synergy theory believes that labour (employee) is the most viable, vibrant and valuable factor in the firm, but least considered and treated as an element of hire and fire - use and dump (Nwonyuku, 2015c). An employee thus, is the most delegated and relegated in the course of meeting the corporation objective. The concept is of the view that employee has very little regards in the leadership structure. Accordingly, this negative attitude of the owner that is just a factor of production against the employee, another key factor of production is the remote cause of firm failure more than anything else (Nwonyuku, 2015c). This is because there 
is no true alignment of value between the two human factors in the production setting (Nwonyuku 2015c). According to the concept, when firm owners begin to ascribe value to employee and see them as equal important that can create value, higher value will begin to flow out of them. This is the basis of value-synergy approach of organization. It is the use of value to derive higher value. Value-synergy approach is also regarded as valueinclusiveness approach. In this perspective, every component of the organization is given regard and high esteem. Concentration is not only focused on the top management board alone. Employee interest is internalized by giving them place in the leadership structure. This is unlike other theories in corporate governance, where virtually all directors serving on the boards are imposed from outside, and making the leadership to seen as opportunists who have few time to stay and feed on the value other factors of production such as employees have grown over the years (Nwonyuku, 2015c). Thus, the value-synergy postulation believes that as the interests of other legitimate groups are met, the value creation objective of the firm becomes easier and done unconsciously. However, financial expropriation affinity creeps in when there is sense of insecurity, sense of disrespect, loss of value, loss of sense of belongingness, loss of collective ownership ideology, loss of accountability, poor empowerment, and lack of transparency. Consequently, when the other components in the value-chain have the feelings of being unimportant, using legitimate but un-gainful approach to dispose the assets of the organization will eventually gain ground. But, these factors can be ethically controlled by making every stakeholder to feel relevant, included and work as a unifying factor.

According to Garcia, et al. (2008), employees are influential stakeholders whose welfare is internalised to a certain extent by top managers through co-determination systems of governance, having small percentages of the firm's total stock in free - float, and making the mangers' compensation not so focused on current profitability. Our aspiration for sound corporate governance can only be met when corporate governance system is designed to keep making better off the firm's workforce (Nwonyuku, 2015c). According to Nwonyuku (2015c), an organization should be seen as a system of networking where value is created for all contributors of resources and leadership positions are allocated among the direct contributors - investors, employees, credit facilitators, customers, and suppliers, and that none of these parties should allow the influence of outsiders to distort the valuesynergy effect of the firm. Thus, the three key participants in the corporate process should be the board of directors (representative of investors), management, and the other employees, that can communicate directly with each other within and outside the confines of the board to share critical information about the business of the corporation. Therefore, in order to maximize corporate value with ease and certainty, all legitimate parties should be given equal opportunity for growth without any element of bigotry. According to Nwonyuku (2015c), this is achievable through inclusive leadership arrangement that centres on: Transparency (T), Empowerment (E), Accountability (A), Courage (C) and Humility (H), this is, "TEACH" Principle of inclusiveness. These inclusive leadership traits tend to trigger intrinsic energy that will influence employees' behaviour to generate exceedingly high performance. It is when the employee feels that his interest is being internalized in the organizational structure that the corresponding and lasting happiness will yield the desired intrinsic value that when merged with the investor's value will produce the desired and sustainable performance for the firm within the shortest possible time (Nwonyuku, 2015c). The value-synergy approach therefore believes that where the behavioural factor of every resource provider is considered, ethical consideration will be high; as a result, religious, social, and cultural divide or other form of bias relationship will be shun in the course of networking every legitimate resource provider. This suggests that value-synergy promotes for diversity and competence of human factor of production that will later grow to become board member following excellent performance and contribution in the growth of the firm.

Value-synergy approach considers that the employees should be adopted and incorporated into the leadership structure of the firm as an intrinsic value provider and allocates them with equal opportunity to reach to the highest echelon of the organization. This approach also believes that resources must come together to form and run an organization. That by mere promoting the shareholders' value alone is quite unfair and undesirable. To ensure full protection and security of the corporation, and the financial markets at large, the employee protection and security must also be sought for. As a result, the concept of value-synergy does not recognize much oversight function from external environment in the form of non-executive directors. Instead large size of top management team is encouraged. The implication is that large board composition is discouraged since every direct stakeholder should have the full cover of security, which is in turn reflected as together, everyone ensures that the corporation is secured from expropriation attempt. This is on the premise that: An injury to the business is an injury to all. Accordingly, everyone feels happy and shows the sense of belongingness by going extra-mile to ensure the lasting success of the business. Thus, an outsider is seen as a distortion and distraction in the governance system. Hence, board composition tends to be less effective and shows negative correlation with firm performance under this perspective. In the same manner, large board size is discouraged by the postulation since there will be less monitoring and supervision efforts. In this case, agency problem and agency costs tend to be minimal while employees' welfare and the security of the corporation tend to increase. This, it does by building trust, facilitating personality growth and development through constant training and development, creation of leadership position for the employees, consultation, cooperation, improved human relations, collective responsibility and adoption of 
modern organizational and behavioural models. When this assumption is upheld, corporate governance practice will no longer be seen on the basis of enforcement or compulsion, but it will be adopted in an intrinsic manner. Williamson (1964) points out on the manner in which personal interests influenced decisions. Accordingly, his thesis conflicted with the traditional view assumed in accounting theory that the interests of shareholders and managers are joined in the maximization of shareholders' wealth. This view of Williamson might be old and unimaginable, but its content is beginning to be realizable as owners' value begins to merge with the employee's intrinsic value to yield value-synergy effect (Nwonyuku 2015c). Accordingly, to regain the confidence of financial markets, a revolutionary approach to corporate governance is necessary (Tipgos and Keefe, 2004).

\subsubsection{Profitability as a Measure of Firm Performance}

Tailab (2014) identifies two kinds of performance measurements to include: Financial Performance and Nonfinancial performance. According to him, profitability is one of the ways financial performance can be measured. In the view of Omondi and Muturi (2013), profitability can be used as a proxy for financial performance. Usually, financial performance indicators could include profitability, efficiency, leverage and liquidity. Also, the key indicators that may be selected to measure financial performance of companies are functions of investigator's interest and availability of data, among other factors. This research work tends to measure firm performance based on those financial performance measurements that are strategically and functionally important to the success of the selected companies. In that order, the research would measure financial performance of the firms by focusing on profitability. Profitability indicates the efficiency and effectiveness with which management used the resources of the company to earn profit and create value to shareholders. Profitability therefore is the measurement of board of directors' (management's) financial performance in the utilization of company's available resources (physical, material, and human resources) in generating returns to the owners on their investment in the business. In its simple term, profitability is the capacity of the persons charged with the responsibility to direct and control the affairs of a corporation to generate profits from the assets base of the company. It is the measure of the rate of return from the assets or capital employed at a given period of time. This measurement is performed using some key indicators known as profitability ratios. According to Owolabi, Obiakor and Okwu (2011), "profitability ratios are used to evaluate the management's ability or efficiency to create earnings from revenue - generating bases within the organization." In the context of this study, the profitability position of a firm is measured using the return on equity and net assets per share.

\subsubsection{Relevance of Profitability Measurement}

Profitability indices are becoming a basic barometer for benchmarking corporate governance practices and for evaluating compliance levels. Profitability is the reference standard for operating performance. It provides the base for the assessment of overall business performance. High profitability therefore implies increase in shareholders wealth. Profitability measurement is necessary to measure the financial performance of management. It is a central component of corporate governance system. Profitability measure also motivates managers and employees at all levels of the organization to strive to meet organization goals. It is therefore a key element for motivating individuals in an organization. Drucker (1968) observes that it is unfortunate that the word "profit" is looked upon as a term of abuse since some firms always want to maximize profits at the cost of employees, customers and society. According to him, except such infrequent cases, it is a fact that sufficient profits must be earned to sustain the operations of the business to be able to obtain funds from investors for expansion and growth and to contribute towards the social overheads for the welfare of the society. Pandey (2010) adds that a company should earn profits to survive and grow over a long period of time. Profitability indicators are important to measure the operating efficiency of the company. Besides management of the company, creditors and owners are also interested in the profitability of the firm. Creditors want to get interest and repayment of principal regularly. Owners want to get a required rate of return of their investment. This is possible only when the company earns enough profits (Pandey, 2010:594). Profitability measurement is useful in making important business decisions. Shareholders use it to make investment decisions based on their analysis. Potential investors need it to weigh the viability of investing in a company. Investors may predict future dividends based on the profitability measurement of a company. Employees use profitability measurement to determine the effects that they may have on future pay and job security. Competitors compare their profitability measurement with rival companies in the same industry and with related size to learn and develop strategies to improve their operations. Also, governments require profitability measurement to determine the correctness of tax declare in the tax returns.

\subsubsection{Relationship between Corporate Governance and Profitability of Firms}

There has been an intuition that a relationship exists between corporate governance and profitability of firms. Theoretical frameworks as well as regulatory agencies of corporate governance have emphasized deeply on the association between corporate governance practice and firm profitability. Conceptually, progression in corporate governance suggests possible improvement in firm profitability. Aggarwal (2013) observes that considerable theoretical and empirical researches have been done globally to study the relationship between corporate 
governance and corporate profitability. Eisenhofer (2010) states broadly the conclusion has been that "Good Governance Does Pay". Selvaggi and Upton (2008) stated that good corporate governance causes good firm performance. Oteh (2013) also confirmed that a published on the link between Corporate Governance and Organizational Performance found strong relationships for a number of corporate variables and firm performance measures. The persistent corporate failures that occurred over the past few years are hence, sufficiently enough to have become evidence that corporate profitability is a core element of corporate governance. 2011 SEC code confirmed that weak corporate governance has been responsible for some recent corporate failures in Nigeria. The aftermath of this position shows that a relationship does exist between system of corporate management and corporate survivability. It has shown that without high and steady stream of earnings, a company will not be able to survive any corporate shake-up. Firm profitability is hence, "a life wire instrument for evaluating, monitoring managerial and measuring performance of directors including the overall roles of the Board in maintaining the wheel of an entity" (Nwonyuku, 2012a:5). Accordingly, the overwhelming effect of corporate governance on the profitability suggests that, there is a strong tie between these two different variables. In spite of this, Pandey (2011) has noted that conclusive evidence connecting good governance to good performance has been lacking and the existing studies have yielded mixed results. Mani and Sreedharan (2004) also confirm that the conclusiveness of studies varies across countries. It is therefore surprising given that many academic investigations did not report statistical relationships between the variables (Hermalin and Weisbach, 1998; Nickell, et al, 1997; Heracleous, 2001; Barkema and Gomez - Mejia, 1998; Michael, at al., 2006). And in some other studies, researchers found that there were indications of negative connections between corporate governance and firm performance, as well as mixed results that made the studies inconclusive. Oluwafemi, at al. (2013), also confirmed that empirical evidence on the relationship between corporate governance and performance is mixed. Different analogies selected from empirical results are considered. Drobertz, Schillhofer, and Zimmermann (2003) explore the relationship between firm - level corporate governance and firm performance and suggest that good corporate governance leads to higher firm valuation (performance), hence, investors are willing to pay a premium and bad corporate governance is punished in terms of valuation discounts. Balasubramanium, et al. (2008) found a positive association between India Corporate Governance Index and Tobin's Q Value (used as proxy for market value of firm) and further this relationship was stronger for more profitable firms and firms with higher growth prospects. Gompers, et al. (2003) and Sachs (2007) found that highly governed companies significantly outperform the investments made in poorly governed companies. In Tanko and Kolawole (2007), a study conducted by MCkinsey (2003) found that $80 \%$ of the respondents would pay a premium for well governed companies. The research has been able to capture a perceived interest of investors that are willing to pay premium for good corporate governance. Thus, investors tend to favour companies that are perceived to be well-governed. Aggarwal (2013a) concludes that corporate governance has a positive and significant relationship with financial performance. Similarly, Brown and Caylor (2004) and Aggarwal (2013b) found positive association between corporate governance scores and financial performance of firm. Governance Metrics International and Byun (2006) found that companies with higher governance ratings enjoyed higher profits and returns. Mani and Sreedharan (2004) found that superior corporate governance practices of firm are positively and significantly correlated to market valuation of firm. Klapper and Love (2003) report that better corporate governance is highly correlated with better operating performance. Van de Velde, et al. (2005) observed that portfolios with above - average governance scores outperformed the portfolios with below - average governance scores. Ashaugh-Skaife and Lafond (2006) discovered that firms with higher corporate governance scores demonstrate lower risk to investor, and thus, enjoy lower cost of capital. Black, Jang and Kim (2003) provide empirical evidence that there is a positive correlation between corporate governance and firm performance. Drobertz (2004) also finds that higher corporate governance rating is related to high performance.

However, the works of Heracleous (2001) in Tanko and Kolawole (2007); Yermack (1996); Claessens, et al. (1999); Klapper and Love (2002); Gompers, et al. (2003); and Black, et al. (2003) reported inconclusive results as their findings. Heracleous (2001) concludes that, studies have failed to find any convincing connection between the 'best practice' in corporate governance and organizational performance. More so, Barkema and Gomez-Mejia (1998) in Tanko and Kalawole (2007) argue that firms governance structure play no significant role in the study of CEO and performance of firm. Also a study conducted by Michael, et al. (2006), concludes that there is no significant relationship between the governance control mechanism and firm performance. Chidambaram, et al. (2006) found no significant performance difference between firms with good governance changes and firms with bad governance changes and thus, rejected the hypothesis that better governance leads to better financial performance. This result is consistent with those of Core, et al (2006); and Statman and Gluskhov (2009), who found no significant relationship between corporate governance and firm performance. More so, Azim (2012) finding suggests a mixed and inconclusive result of the relationship between corporate governance and profitability of firms. Mukherjee and Ghosh (2004) found that there is no significant relationship between corporate governance and corporate financial performance. More so, the inventory of empirical studies on corporate governance and firm profitability shows inconsistent results (Roth and O' Donnell, 1996; Long, et al. 


\subsubsection{Review of Empirical Studies}

The link between corporate governance and profitability has been strongly discussed in almost all the developed and developing economies. While many results have shown the evidence that corporate governance is relevant to firm's profitability because it provides the policies, principles and procedures through which the corporate value is maximized. There are some other empirical findings that demonstrate negative and inconclusive results of the relationship between corporate governance and profitability of firms. This paper thus, aimed at consolidating such reliance on the use of profitability to determine the performance of corporate governance of food and beverages firms in Nigeria.

\subsubsection{Review of Empirical Studies in Other Countries}

A review of the empirical evidence on the impact of board size on performance shows mixed results. A study conducted by Kashif (2008) on comparison of corporate governance and firm performance in developing Malaysia and developed Austrian Financial Markets indicates that board size is positively associated with the performance surrogate - return on equity. A similar study conducted by Zubaidah, Nurmala, and Kamaruzaman (2009) in Malaysia also showed the same result. Dehaene, et al. (2001), find that board size is positively related to company performance. The regression results of the relationship between board size and firm performance investigated by Tornyeva and Wereko (2012) indicates a statistically positive but weak relationship between board size and return on equity (ROE). According to them, the result implies that larger boards are better, thus, the larger the board, the better the performance of the company. This position is premised on the assumption that larger boards are constituted with members from different backgrounds that bring to the board different skills and professional expertise. This would facilitate better decision making and place the board in a better position to monitor the activities of management. The result also gives support to the resource dependence theory that believes that directors are not burden and thus should not be seen as source of company expropriation of funds and increasing agency costs. However, the research conducted by Chiang 2005) shows that there is a negative but insignificant relationship between board of directors' size and operating performance measures of return on equity (ROE). More so, financial ratios related to profitability and operating efficiency appear to decline as board size grows. In Malaysia, Amran (2011) studied the relationship between board characteristics and performance of firms using panel data methodology, and the result reveals that board size has a significant negative relationship with firm performance. In Ghana, Adusei (2011) investigation of the relationship between board structure and firm performance using panel data reveals a negative association between board size and profitability of firms. The finding implies that as size of firms' board of directors decreases its profitability increases. The implication of this finding is that, companies with large boards appear to use assets less efficiently and earn less profit. Connelly and Limpaphayon (2004) find that board size does not have any relation with firm performance. Aljifri and Moustafa (2007) employed cross-sectional regression analysis technique to find out the impact of board characteristics on performance of firms in United Arab Emirates; and the result reveals that board size has an insignificant impact on performance of firms. Finally, the results of Haniffa and Hudaib (2006) are inconclusive.

Empirical evidence available on the relationship between board composition and firm profitability shows mixed results. Dehaene, et al. (2001), find that the percentage of outside directors (board composition) is positively related to the performance of Belgian firms. Connelly and Limpaphayom (2004) find that board composition has a positive relation with profitability of firms in Thailand. In Pakistan, Ibrahim, et al. (2010), study the impact of corporate governance on performance of Pakistan chemical and pharmaceutical companies; and the results of the investigation indicate that board independence has positive impact on return on equity. Rosenstein and Wyatt (1990) find a positive stock price reaction at the announcement of the appointment of an additional outside director, implying that the proportion of outside directors' affects shareholders' wealth. However, Tornyeva and Wereko (2012) found that board independence has a negative and weak relationship with return on equity. Further in Tanko and Kolawole (2007), a study conducted by Dalton, et al. (1998) based on variables like operationalization of board composition and the nature of the performance indicators conclude that there is no evidence of a substantive relationship.

Empirical findings of the relationship between board gender diversity and firm profitability show mixed results. In the United States of America, Erhardt, et al. (2003) results show that board gender diversity have a positive correlation with firm financial performance; and the implication is that, an increase in the number of female directors on the boards will turn out to improve the firm profitability since it will expand the culture, rules, structures, processes, knowledge, skills, expertise and competence of the boards in ensuring efficient operation of the business entity. Bathula (2008) study shows that gender diversity was positively associated with firm performance. Rose (2007) also studied the impact of female board representation on firm financial performance of selected quoted Danish companies and the result shows that gender diversity does have significant impact on financial performance. According to the findings of Luckerath-Rovers (2011) in Netherlands, the presence of one or more female directors on the board relates positively and significantly to return on equity. A striking result that 
follows from her study is that higher return on equity is consistently and statistically significant for companies with women on the board than for companies without women on the board. These results suggest that on average the presence of women on the board is a distinctive feature of companies that perform better (Luckerath-Rovers, 2011). In general, Chiang (2005) finds that companies with good corporate governance have a significant positive relationship with operating performance measures in ROE.

\subsubsection{Review of Empirical Studies in Nigeria}

Relationship between corporate governance and profitability has been studied by many researchers in Nigeria. The result of the study conducted by Okougbo (2011) on corporate governance and firm performance of 52 listed nonfinancial companies in Nigeria using panel estimation based on the Generalized Least Square regression of fixed effects shows that the relationship between board size and return on equity is positive and significant. The result of Mutalib (2012) study of corporate governance and the performance of food, beverage and tobacco industry in Nigeria indicates that board size has significant impact on net assets per share. The result of empirical study carried out by Babatunde and Olaniran (2009) on the linkage between corporate governance mechanism and performance of corporate firms in Nigeria shows that there is a positive relationship between board size and return on equity. Tanko and Kolawole (2007) result indicates that board size has a positive and significance relationship with firm performance measured by return on equity. Result from the study conducted by Uadiale (2010) indicates that there is strong positive association between board size and corporate financial performance - return on equity. In a sample of 248 companies employed to study the impact of corporate governance on firm's performance in Nigeria using panel data random effect analysis, Dabor, et al. (2015) result indicates that there is a positive but statistically insignificant relationship between board size and return on equity. All the results indicate that increase in board size would increase the performance of the firm. This confirms the view that larger boards are better for corporate performance because members have a range of expertise to help make better decisions. Also, the findings indicate the need for increase in board size and support the view that larger boards are better for corporate performance because members have a range of expertise to help make better decisions, and are harder for a powerful CEO of the firm to dominate. However, Sanda, et al. (2005) studied the linkage between corporate governance mechanisms and financial performance of Nigerian firms using pooled ordinary least squares regression analysis technique; and the result shows that board size has a negative relationship with return on equity. Mutalib (2012) result also indicates that there is no significant impact of board size in relation to return on equity of firms in food, beverage and tobacco sector of Nigerian economy.

On board composition, Uadiale (2010) empirical evidence available shows that there is a positive association between outside directors sitting on the board and corporate financial performance measures - return on equity. Tanko and Kolawole (2007) study shows that board composition has a positive and significant association with firm performance in terms of return on equity. This means that the more outsiders there are on a company's board, the better the performance in terms of return on equity. The implication is that when a board is deemed independent, performance of companies becomes better. The results show that where there are more outside directors, they will support the beneficial monitoring and advisory functions thereby strengthening the monitoring of the shareholders fund. In this regard, the composition of the board of directors should be more outsiders. However, there are also fair amount of empirical findings that tend not to support the positive relationship of board composition with firm profitability. Dabor, et al. (2015) result indicates an insignificant negative relationship between board composition and return on equity. The finding shows that improved performance of firm is not dependent on increasing the number of board composition. This implies that when there are more external board members, performance of firms tend to be worse off and recommend decrease in board composition. Oluwafemi, et al. (2013), identify that empirical research results of impact of outside directors on firm performance are mixed. According to them, there appears to be generally no empirical evidence that the existence of outside directors is correlated with firm performance. On the side of gender diversity, Result from a study conducted by Dabor, et al. (2015), show insignificant negative relationship between board gender diversity and return on equity.

\subsection{RESEARCH METHODOLOGY}

\subsection{Research Design}

The research theme is the determination of the influence of corporate governance on profitability of food and beverages firms in Nigeria. The study is based on qualitative and quantitative analyses. The qualitative analysis is based on the theoretical, regulatory and previous studies of corporate governance. The quantitative analysis is based on data collected from the sample size drawn from the study population. The population of the study is 23 listed food and beverages firms, and sample size of eight (8) was drawn using random sampling technique on the basis of census to provide answers to the research questions and test formulated hypotheses. The timing of the study spanned from 2004 to 2014, which is a period of 11 years. The choice for this period is to determine the post effect of the code of corporate governance on performance which was introduced in Nigeria for the first time in 2003 by Nigerian Securities and Exchange Commission. The research methods are mainly adopted from four 
previous studies by Okougbo (2011), Tornyeva and Wereko (2012), Uadiale (2010) and Dabor, et al. (2015). More so, secondary data collection technique was employed using mainly annual reports and accounts as well as other documents of the selected companies. Also, in order to provide answers to the research questions and to test the formulated hypotheses as well as to control variance as validly, objectively, and accurately as possible, the study employed basic descriptive statistics to determine the measures of central tendencies and dispersion and inferential statistics to ascertain the casual linkages and to predict the future outcomes of the dependent variables. In order to achieve the research objectives, the study employed board structure indicators found in Okougbo (2011), Tornyeva and Wereko (2012), and Dabor, et al. (2015) that was used to predict various profitability measures in a set of correlation tests, using firm size as a control variable. The authors used correlation tests followed by a panel data analysis of Ordinary Least Squares (OLS) multiple linear regression models to carry out inferential statistics and analyse the collected data. Accordingly, the use of this model was to enable the control of independent variables to forestall the operation of extraneous and unwanted sources of systematic variance. Thus, "the research design criterion is pertinent to ensure generalizability, validity and reliability of the study" (Okereke, 2001: 59 - 60) should different samples are drawn from the target population for the same purpose.

\subsubsection{Sample Size and Sampling Techniques of the Study}

From the population frame of 23 listed food and beverages companies in Nigeria as at 31 December, 2014, a sample size of eight (8) companies representing about 35 per cent of listed food and beverages firms in Nigeria. The sampling procedure employed is the census strategy of random sampling technique. This technique is preferred to others because it gives equal opportunity for every element to be selected from the population frame. In view of the outlined objectives of this research, certain contributions have been satisfied by firms selected for the final analyses. Therefore, three companies were eliminated because of inadequate financial and non-financial information. Five firms were excluded because their shares were not constantly traded for the time this investigation was undertaken. In a similar manner, five firms were not included because the shares of the companies were not listed on the Nigerian Stock Exchange (NSE) prior to or as at $31^{\text {st }}$ December, 2004. Finally, two companies were eliminated because of being extremely diversified or conglomerated and the use of their annual reports and accounts could distort the entire result. Following the sample size of eight firms selected for the period of 11 years ranging from 2004 to 2014, it is therefore obvious that the study employed 88 data observations.

\subsubsection{Methods of Data Collection}

There are several techniques of data collection, namely, the use of interview, use of documents and use of questionnaire. This study employed the use of documents. This is following the shortfalls in the other techniques. Particularly, the use of interview and questionnaire could involve time consuming, energy sapping and expensive to carry out. Also, there could be communication gap and electric power, internet and telephone interruptions. They involve skills like maintenance and establishment of rapport and high confidentiality (Nwonyuku, 2005: 78). Further, Nwonyuku (2005) notes that they do not cover the entire population due to it is only the knowledgeable respondents will respond to it; data-blank mode questionnaire are difficult to code and to carry out statistical analysis; responses could at times be shallow and therefore, unreliable. It could face the problem of unreturned questionnaire as well as the possibility of misinterpretation of the questions. More so, the researcher may be unable to relate the questions to the research questions, objectives and hypotheses, thus, losing the validity of the research result. It is as against the backdrop that this investigation employed the use of documents coupled with observation and measurement as the method of data gathering. This method is cheap, readily available and saves time. Document is an already existing data material that is, secondary data instrument, and could be sourced from textbooks, newspapers, journals, magazines, workshops, seminars, conferences and meetings (Nwonyuku, 2005:78); from publications like company's annual general meeting reports and accounts, internet sources, articles, editorials and previous research works. More so, the method gives stability, dependability, predictability and precision of the collected data as well as ensures reliability and validity of research objectives, questions and hypotheses outcome. As a result, the findings from this investigation could be generalized and stood to the test of time.

\subsubsection{Source of Data Gathering}

In any social science research, data as an important component for investigation is collected from basically two sources: primary and secondary. While the primary source of data involves the use of methods like questionnaires and interviews which may involve direct contact from persons and/or areas involve; and consequently, it is surrounded by the problems associated with questionnaires and interviews techniques. The secondary data involves the use of documents method of data collection. This study employed the secondary source of data gathering because of its convenience, sufficiency, availability and accuracy over the primary sources of data collection. The data for the research was obtained from databases that can be described as external secondary sources (Stewart 
and Kamins, 1992), meaning existing sources of information collected by others and archived in some form. Stewart and Kamins (1992) point out that secondary source of data collection offer a relatively quick and inexpensive solution for research compared to primary sources of data. According to Bajpai (2011), this is particularly useful for studies where collecting the required data would be challenging or when the researcher needs easily accessible company information, such as sales or revenue information about companies.

\subsubsection{Instruments for Data Collection}

The research employs quantitative data collection instruments since the study used numbers in the form of financial ratio. The instrument adopted to collect the quantitative data is the Nigerian Stock Exchange Fact book 2013/14, African Financial portals and directly from the websites of the selected companies where the annual reports and accounts of the companies were extracted for the periods covered in this study. The three instruments of data gathering for this study indicated as the most reliable and relevant, as they are objective and independent providers that gather information from various sources of publicly listed companies, such as annual reports and accounts, news and publications. The data collections cover the time period and publication of interest and the risk of bias is low compared to instruments of data collection from primary sources of data collection methods. This is particularly important as corporate governance is a complex area and there is no standard way of measuring corporate governance performance.

\subsubsection{Reliability and Validity of Instruments for Data Collection}

Nunnally (1978) describes reliability as "the extent to which results are consistent over time and provide an accurate representation of the total population under study." In other words, reliability is the consistency and stability of findings, which enables findings to be replicated (Burns and Burns, 2008: 410). Nunnally (1978) and Vaus (2011) note that, in practice a measure is reliable when it can be used to reproduce the same result when repeated on occasions. Burns and Burns (2008) emphasize that accuracy and stability of a measure are the two most important characteristics of reliability. The reliability and validity in secondary data are mostly functions of the method and the sources by which the data were collected (Lewis, et al. 2009). In the previous sections, the instruments for data collection and analysis were mentioned and discussed to include: observation, measurement and documents. The use of these instruments all through this study were consistent, accurate, predictable, and stable to ensure that they measured what they purported to measure in the context of the study. Thus, relevant concepts, characteristics, regulatory and theoretical frameworks of dependent and independent variables as well as control variables were explored to show representativeness or sampling adequacy of this discourse. The coverage was adequate and qualitative enough to address the research problems, answer research questions, and to achieve the desired research objectives. This was accomplished through frequent reference to related and relevant literature both from international and domestic research works "based on the similarity in research design and instruments for data analysis." As a result, this study is based on methods used by Okougbo (2011), Uadiale (2010), Tornyeva and Wereko (2012) and Dabor, et al. (2015), which proves the reliability of the results and the research design. Nonetheless, this research is still an individual study that has been adapted from other relevant studies, rather than a reproduction of previous studies. Further investigation would be needed to confirm the reliability of the results. More so, Lewis, et al. (2009), state that reliability of secondary data is related to the reputation of the source. The validity and reliability tests of the research instruments were "enhanced with the use of only published annual reports and accounts of selected companies" obtained from well-recognized sources. As Nigerian Stock Exchange Fact books and African Financials Portal are the leading business data providers, the source can be confirmed as reliable and the original data sources from Nigerian Stock Exchange Fact books and African Financial Portal are often verified by third-parties, as the sample consists of listed companies. More so, the data analysis instruments employed in the study have theoretical background of financial or economic encumbrances and have been used by previous researchers in the same and related field of study; hence this enabled the researcher to compare methodology and findings from past studies with the result obtained from the data analysis instruments - panel data model and descriptive statistics. To this end, it is assumed that different measures of the same empirical construct should yield fairly highly related result, where all factors remain unchanged.

On the other hand, validity could be either internally or externally measured or even the both. According to Burns and Burns (2008), internal validity refers to the capacity and appropriateness of a research design to assess the casual conclusions it purports to measure. It is the extent to which the structure of research design enables us to draw unambiguous conclusions from the results (Vaus, 2001: 28). Vaus (2011), refers external validity to "the extent to which results from a study can be generalized beyond the particular study." It means whether the outcomes of a sample are transferrable to a population (Burns and Burns, 2008). As stated earlier, Nigerian Stock Exchange Fact books and African Financials Portal were identified as the most appropriate data source for this study, and fulfilled all the assessment criteria. In addition, there is a low risk of bias or error in the values, as data have been provided by independent sources rather than collected by the researcher. Therefore, the internal validity of the research is high and by extension to the external validity, the result from the sampled companies can be transferred to the entire food and beverages firms in Nigeria. Even though certain assumptions can be drawn from the results and other similar studies, the findings primarily apply to the 23 listed food and 
beverages companies in Nigeria out of about 206 publicly quoted companies and 1.371 million companies (both private and public) in Nigeria as at the time of this study. This according to Burns and Burns (2008) refer to a low "population validity," as the sample is less likely to provide results that can be transferred to a larger population. This is not to say that secondary sources do not have strong external validity, which improves the generalizability of findings to a larger population.

\subsubsection{Instruments for Data Analysis}

The econometric instruments for data analysis adopted in this study include the use of basic descriptive statistics. Also, inferential statistics tools employed for analysing the underlying statistical tests like the regression tests and the test of correlation is Multiple Linear Regression Analysis which is estimated with the Ordinary Least Squares (OLS) in a Panel Data manner to explain the impact of corporate governance on profitability of firms in Nigeria, while the test of correlation measures the degree of association of the corporate governance characteristics with the profitability indicators employed for the study. This model is also referred to as Balanced Panel Data Analysis because of its ability to use cross - sectional and time series data. These statistical instruments have been used by numerous researchers for many years and have been confirmed reliable (Dabor, et al, 2015; Tornyeva and Wereko, 2012; Okougbo, 2011; Velnampy, 2013; Kajola, 2008; Aggarwal, 2013a \& b). Multiple linear regression is a technique in which more than one independent or explanatory variable is used to predict the value of the dependent variable (Burns \& Burns, 2008; Eye \& Schuster, 1996). More so, OLS multiple linear regression is the most widely used type of regression for predicting the value of one or more than one dependent variables from the values of two or more independent variables because, it gives equal importance to all the items in the time series, the older and the more recent.

Panel Data Analysis (PDA) involves the pooling of observations on cross - section of units over several time periods and provides results that are simply not detectable in pure cross - sections or pure time - series studies (Tornyeva and Wereko, 2012). The panel nature of the data permits the estimation of dynamic "corporate governance" models over the business cycle at the level of the individual firm, to test both the persistence and cyclical of firm profitability (McDonald, 1999). Panel data model allows controlling for variables which cannot be observed or measured or for variables that change over time and not cross entities, and therefore, this approach has advantages compared to the cross - sectional approach often used in financial research (Pratheepan, 2014:5). The model is grounded in financial or economic reasoning, with variables that are appropriate functional forms for their nature. It has specifications that are parsimonious and it is in compliance with the regression assumptions. Panel data regression provides better results since it increases sample size and reduces the problem of degree of freedom. According Solomon, et al. (2012), the use of panel regression would avoid the problem of multicollinearity, aggregation bias and endogeneity problems. However, the pooled data analysis neglects the heterogeneity effects in the sampled firms. In spite of this the panel data was preferred as it provides better results. More so, it has been tested out-of-sample before applying them to decisions. Based on the above, it is therefore a convenient method of analysing the collected data for the purpose of achieving the research objectives. Thus, all data were prepared and statistically analysed using econometrics software applications of E-view version 8.0. On the aspect of establishing whether correlation exists among the independent variables, three violations of correlation coefficient estimate may occur. They are hetroskedasticity, serial correlation and multicollinearity. This study adopts multicollinearity test. Kothari (2004) notes that in multiple regression analysis, the regression coefficient become less reliable as the degree of correlation between independent variables increases. If there is a high degree of correlation between one independent variable and another independent variable, the problem of multicollinearity, or simply called collinearity will occur. Its presence shows correlation coefficient estimates to be consistently high between the independent variables, but imprecise and unreliable. Another indicator to know its occurrence is the presence of a significant $\mathrm{F}$ - test but with no or low significant $\mathrm{t}$ - tests.

\subsubsection{Model Specification}

Pooled Ordinary Least Squares (OLS) with Multiple Linear Regression Analysis in the panel data framework is used in the study to investigate the nature of relationship between corporate governance and profitability of food and beverages firms in Nigeria. This covers eight (8) firms for the time period of 11 years spanning from 2004 to 2014. Econometrically, the set up to investigate the relation between corporate governance and firms profitability variables is expressed in equation form; the prediction model can be specified in a general form as:

$\mathbf{Y}_{\mathrm{it}}=\boldsymbol{\beta}_{\mathbf{0}}+\boldsymbol{\beta}_{\mathbf{n}} \mathbf{X}_{\mathrm{it}}+\boldsymbol{\varepsilon}_{\mathrm{it}}$

Where:

$\mathbf{Y}_{\mathbf{i t}}=$ Dependent variable of firm, $\mathrm{i}$ in time, $\mathrm{t}$ (firm profitability indicators);

$\boldsymbol{\beta}_{\mathbf{0}}=$ Constant term or intercept of the explanatory variable regression line;

$\boldsymbol{\beta}=$ Regression coefficient or slope or gradient of the explanatory variable (corporate governance characteristics);

$\mathbf{n}=$ serial number of regression coefficient of the explanatory variables in the prediction model; $\mathbf{X}_{\mathbf{i t}}=$ Explanatory or independent or predicting or regressing variable in the estimation model of firm, $\mathrm{i}$ in time, $\mathrm{t}$;

$\boldsymbol{\varepsilon}_{\mathbf{i t}}=$ Error term or residual random element of firm, i in time, $\mathrm{t}$ (assumed to have zero $(0)$ mean and independent 
across time period).

This estimation model has underlying assumptions to include:

i. The relationship between the dependent variable, $\mathbf{Y}_{\mathbf{i t}}$, and the independent variable, $\mathbf{X}_{\mathbf{i t}}$ is linear.

ii. The independent or explanatory variable, $\mathbf{X}_{\mathbf{i t}}$ is not random. Also, no exact linear relation exists between two or more of the independent variables.

iii. The expected value of the error term, $\boldsymbol{\varepsilon}_{\mathbf{i t}}$, conditioned on the independent variable, is zero.

iv. The variance of the error term, $\boldsymbol{\varepsilon}_{\mathrm{it}}$, is the same for all observations.

v. The error term, $\boldsymbol{\varepsilon}_{\mathbf{i t}}$, is uncorrected across observations.

vi. The error term, $\boldsymbol{\varepsilon}_{\mathbf{i t}}$, is normally distributed.

Further, by expressing the general prediction equation in the variables under consideration, we have:

Profitability (PROF) $=\boldsymbol{f}$ (Corporate Governance)

$\mathrm{PROF}_{i \mathrm{t}}=\boldsymbol{\beta}_{\mathbf{0}}+\boldsymbol{\beta}_{\mathbf{n}}\left[(\text { Corporate Governance })_{\text {it }}\right]+\boldsymbol{\varepsilon}_{\mathbf{i t}}$ I

In order to ensure robustness of the model and to reduce specification bias, the prediction model also includes control variables, making the general formula to be further represented as:

$\mathrm{PROF}_{\mathrm{it}}=\boldsymbol{\beta}_{\mathbf{0}}+\boldsymbol{\beta}_{\mathbf{n}}\left[(\text { Corporate Governance }+ \text { Control variable })_{\mathrm{it}}\right]+\boldsymbol{\varepsilon}_{\mathbf{i t}} \ldots \ldots \ldots \ldots \ldots$ II

By specifying the corporate governance into the four characteristics under study: board size (BS), board composition (BC), board skills and competence (BSC) and board gender diversity (BGD) as well as the control variable included in the study: firm size (FS), we have:

Profitability $(\mathrm{PROF})=\boldsymbol{f}(\mathrm{BS}, \mathrm{BC}, \mathrm{BSC}, \mathrm{BGD}, \mathrm{FS})$.

If these various mechanisms are substituted in equation II, the prediction model will be restated as specific form and represented mathematically as:

$\mathrm{PROF}_{\text {it }}=\beta_{0}+\beta_{1} \mathrm{BS}_{\text {it }}+\beta_{2} \mathrm{BC}_{\text {it }}+\beta_{3} \mathrm{BSC}_{\text {it }}+\beta_{4} \mathrm{BGD}_{\text {it }}+\boldsymbol{\beta}_{5} \mathrm{FS}_{\mathrm{it}}+\boldsymbol{\varepsilon}_{\mathrm{it}} \ldots \ldots \ldots \ldots \ldots \ldots$ III

Where:

$\boldsymbol{\beta}_{1}-\boldsymbol{\beta}_{5}=$ Beta coefficients of the explanatory and control variables (BS, BC, BSC, BGD, FS);

$\mathbf{B S}_{\mathbf{i t}}=\mathbf{a}$ vector of size of board of directors variables of firm, $\mathrm{i}$ in time, $\mathrm{t}$;

$\mathbf{B C}_{\mathbf{i t}}=\mathrm{a}$ vector of board composition variables of firm, $\mathrm{i}$ in time, $\mathrm{t}$;

$\mathbf{B S C}_{\mathbf{i t}}=\mathrm{a}$ vector of board skills and competence variables of firm, $\mathrm{i}$ in time, $\mathrm{t}$;

BGD $_{i t}=$ a vector of board gender diversity variables of firm, $i$ in time, $t$;

$\mathbf{F S}_{\text {it }}=$ a vector of control variables of firm, $\mathrm{i}$ in time, $\mathrm{t}$.

This is also built on the models of previous studies (Kajola, 2008; Tornyeva and Wereko, 2012; Okougbo, 2011; Aggarwal, 2013a \& 2013b). Since the profitability indicators selected for the study include: return on equity (ROE) and net assets per share (NAPS), it therefore follows that, two prediction models would be formed for correlation and regression tests to investigate the nature of relationship between corporate governance and profitability of firms. Hence, the two specification models for the study can be expressed as:

$\mathrm{ROE}_{\mathrm{it}}=\beta_{0}+\beta_{1} \mathrm{BS}_{\mathrm{it}}+\boldsymbol{\beta}_{2} \mathrm{BC}_{\mathrm{it}}+\boldsymbol{\beta}_{3} \mathrm{BSC}_{\mathrm{it}}+\boldsymbol{\beta}_{4} \mathrm{BGD}_{\mathrm{it}}+\boldsymbol{\beta}_{5} \mathrm{FS}_{\mathrm{it}}+\boldsymbol{\varepsilon}_{\mathrm{it}} \ldots \ldots \ldots \ldots \ldots \ldots \ldots \ldots \ldots \ldots \ldots$

$\mathrm{NAPS}_{i t}=\beta_{0}+\beta_{1} \mathrm{BS}_{\mathrm{it}}+\beta_{2} \mathrm{BC}_{\mathrm{it}}+\beta_{3} \mathrm{BSC}_{\mathrm{it}}+\beta_{4} \mathrm{BGD}_{\mathrm{it}}+\beta_{5} \mathrm{FS}_{\mathrm{it}}+\varepsilon_{\mathrm{it}} \ldots \ldots \ldots \ldots \ldots \ldots .2$

Where:

$\mathbf{R O E}_{\mathbf{i t}}=$ Return on equity of firm, $\mathrm{i}$ in time, $\mathrm{t}$;

$\mathbf{N A P S}_{i t}=$ Net assets per share of firm, $i$ in time, $t$.

Where: $\mathrm{i}$ and $\mathrm{t}$ represent the companies and time period from 2004 to 2014 respectively for the study. The sample consists of 88 observations for data from the food and beverages firms in Nigeria ranging from 2004 to 2014 , which is ( 8 firms $x 11$ years $=88)$.

\subsubsection{Measurements of Variables}

In the course of determining the nature of relationship between corporate governance and profitability of food and beverages firms in Nigeria, three variables were employed, which include: Dependent variable, independent variable and control variable.

Measurement of Dependent Variable (Profitability Indicators):

Return on equity (ROE): This is measured by the ratio of profit after tax and preference dividends to total owners' equity (ordinary share capital plus reserves) for the period.

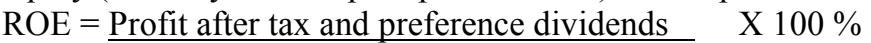

Total owners' equity (shareholders' funds)

Net assets per share (NAPS): This is measured by the proportion of total owners' equity or shareholders' fund (net assets) to the number of ordinary share capital outstanding in respect for the period.

NAPS $=$ Total owners' equity ( shareholders' funds)

Number of ordinary share capital outstanding in respect for the time

X 100 kobo.

Measurement of Independent Variable (Corporate Governance Indices)

Size of the board of directors (BS): This is measured as the natural logarithm of total number of directors serving as board members as at the year ended. $\mathrm{BS}=$ Natural Logarithm of total number of board members. Board Composition (BC): This represents the proportion of total number of non-executive directors and independent non- 
executive directors serving on the board as at the period ended. It can also be referred to as the ratio of independent directors (outside directors) to the total number of board members for the period.

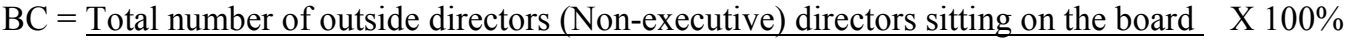

Total number of board of Directors for the period

Board Skills and Competence (BSC): In considering Kolb, et al. (1974) learning cycle, there are four types of learners: concrete, activist, theorists and reflectors. Also, Blue Ribbon Panel on healthcare Governance, BRPHG (2009) categorizes competencies as threshold and differentiating. Threshold consists of generic knowledge, skills, characteristics and behaviours essential to job performance and it is considered as the minimum competence necessary for performance on the job and can apply to the same job industry-wide range of activities. According to BRPHG (2009), differentiating competencies relate to superior job performance for a specific type of organization. Katz and Kahn (1978) identity technical, human relations and conceptual skills as must possessed skills for strategic level. This study measures board skills and competence on the basis of threshold competencies, which include only the theorists and activists. It does not consider technical and human relations skills of the board members. Following the conceptual or threshold competencies basis, board skills and competence $=$ Number of directors sitting on the board with minimum of first degree or its equivalent and/or professional qualifications (conceptual skills of learning) to total number of directors on the board as at the period ended. It is measured in per cent. Board Gender Diversity (BGD): This is used as a proxy for board diversity characteristic in this study. It represents the number of female directors serving on the board of a company to the total number of board of directors in that company as at the period ended. According to Marlin and Geiger (2012), board gender diversity is calculated as the number of female directors divided by the total number of all directors on a given period.

$\mathrm{BGD}=$ Number of women directors serving on the board $\mathrm{X} 100 \%$

Total number of board of directors

\section{Measurement of control variable}

Firm Size (FS): This control variable adopted the measurement used by Ganiyu and Abiodun (2012). It is measured by the natural logarithm of total assets of the firm. This is the size of the firm measured by the value of its asset base. For the regression analysis, natural logarithm of the assets was taken because the values are widely spread. The essence of the control variable is to give recognition to the fact that the profitability of firms especially, food and beverages firms may be influenced by several factors other than corporate governance characteristics. FS = Natural logarithm of total assets of the firm for each year ended.

\subsubsection{Limitations of the Methodology}

Several problems were encountered in the methodology. They are as follows:

1. Complete picture of the activities of a firm cannot be given by the financial statements, for instance, the strength and weakness of management is completely omitted.

2. The factors influencing the profitability of a firm in one year may change in another year and thus could make trend analysis misleading.

3. In most cases, there is no uniformity and consistency in the way and manner the companies in the study present their annual reports and accounts.

4. In some companies' annual reports and accounts, essential components of financial and non-financial data are excluded. This makes it difficult to get such data for research purpose.

Despite these arrays of limitations, the outcome of this study remains reliable and valid for generalization within the industry-specific under investigation.

\subsection{DATA PRESENTATION AND ANALYSIS}

\subsubsection{Data Analysis}

In order to achieve the empirical objective of the study, data gathered and presented were analysed basically in three different results: the basic descriptive statistics result; correlation result and regression estimates results for test of hypotheses.

\subsubsection{Analysis of Basic Descriptive Statistics Result}

The result of the descriptive statistics is as shown in appendix 1, table 1 . The report shows that the variables are both positively and negatively skewed, and the positive value of the Kurtosis signifies that the regression variables are peaked than the Gausian distribution. The Kurtosis values greater than 3 indicates that the variables are Leptokutosis only the board size (BS), board composition (BC) and firm size (FS) values of Kurtosis that are less than 3 which represents Platykurtic distribution. Further, the analysis of size of the board of directors (BS) is in natural logarithm and should be converted to natural number for proper interpretations. The result shows that board size reported a mean value of 1.002208 , which is equivalent to 10 and implies that on the average the sampled food and beverages firms have a board size of ten directors. The board size reported a maximum value of 1.146130, which is equal to 14 indicating a maximum board size of 14 directors. Also, the minimum value of board size reported is 0.845100 , which are 7 directors. The minimum board size as provided by section 4.2 of the 2011 SEC 
code of corporate governance in Nigeria is five; while the 2015 exposure draft of National Code of Corporate Governance for private sectors provided eight members. Subsequently, the selected food and beverages firms' minimum board size of seven exceeded the 2011 code of corporate governance provision of five which fell within the time frame of this study and by implication, the food and beverages firms have a sufficient size relative to the scale and complexity of the sector. Following the newly drafted exposure code, however, the minimum board size of the studied firms should be increased to meet the requirement. The result suggests that on the average, the companies considered in this study have moderate board sizes. This is good in respect of the performance of these companies because it supports recent thinking about board size and is sufficient to attract external resources towards improving corporate profitability. More so, the result of the descriptive statistics shows that the average board composition (BC) of the listed food and beverages firms in Nigeria is $69.82 \%$, the minimum is $46.15 \%$ and the maximum is $85.71 \%$. The 2011 SEC code of corporate governance for public companies in Nigeria provides in section 4.3 that the board should comprise a mix of executive and non-executive directors, and the majority of board members should be non-executive directors; in the non-executive to executive directors factor of 4:1 implies that $80 \%$ of board size should be the maximum proportion of board composition. In this sector, the maximum board composition is about $86 \%$ showing that there is an excessive provision of independent directors serving on the board of food and beverages firms in Nigeria this may likely make them to lose focus and exhibit hidden directors' factor, which perhaps could cause increase in agency cost and reduction of profitability. Even the new NCCG non-executive director to executive director factor is $7: 2$ implies $77.78 \%$ of board size should be the maximum proportion of board composition. This also shows that there is an over recruitment of non-executive directors in this sector. The result of descriptive statistics shows that there is an average of $6.49 \%$ board gender diversity, with the minimum of $0 \%$ and maximum of $28.57 \%$ representing female directors serving on the boards of the listed food and beverages firms in Nigeria. While most other countries have provided in their domestic corporate governance codes that at least one female director must serve on the boards of any quoted company in their countries in order to promote gender diversity, Nigeria is yet to follow suit. The 2003, 2011 and the newly drafted 2015 NCCG for private sectors could not specifically mandate quota for board gender diversity. They basically provided that the board should be composed in such a way as to ensure diversity of experience and gender without compromising competence, independence, integrity and availability of members to attend meetings. More so, section 5.12 of NCCG has indicated that companies should establish a policy concerning diversity and disclose the policy. Yet, this blank provision is not sufficient to say that the regulators recognize the real benefits of board gender diversity mainly in strategic decision making. This could be the reason that the food and beverages firms in Nigeria have a very low average of female directors on their boards. Further, the board skill and competence result shows $100 \%$ on average, minimum and maximum boards members in the sector. All the directors on the boards either have a university degree or its equivalent and/or professional qualifications. This means that the food and beverages firms in Nigeria recognize the importance of job and behavioural competencies. This is as provided in section 4.4 of 2011 code of corporate governance that the members of the board should be individuals with upright personal characteristics, relevant core competences and entrepreneurial spirit. Firm size value is based on natural logarithm. When converted to natural number, the average total assets employed by the sector is $\$ 40,610,655,540.00$, with maximum total assets of $\$ 300,489,983,600.00$ and minimum total assets of N2,569685,654.00. From the side of dependent variables, the companies on average generated return on equity of $7.29 \%$ with maximum of $302.55 \%$ and minimum of $-2071 \%$ respectively. In terms of net assets per share, the mean value was $\$ 13.19$ per share, maximum of $\$ 51.21$ per share and minimum of - $\$ 2.76$ per share.

\subsubsection{Correlation Analysis}

Appendix 2, table 2 shows the correlation matrix of test for multicollinearity, which explains the degree of closeness among the independent variables. From the result of regression estimate of each dependent variable, each of the t-statistics does not have zero value or very low significant value. Also, the analysis of correlation matrix from appendix 2 indicates that there is no high degree of correlation existing between one independent variable and another across the firms. This shows that the independent variables are free from multicollinearity problem in each of the model; making the regression coefficient becomes very reliable in predicting the corresponding dependent variable.

\subsubsection{Analysis of the Results of Regression Estimates}

The result of the pooled ordinary least squares (OLS) regression estimates for prediction model 1 is presented in appendix 3, table 3.1. The result helps to explain the empirical relationship between the dependent variable (return on equity) and the independent and control variables. The explanatory power of the pooled OLS regression model, coefficient of determination or $\mathrm{R}$ - square shows that the prediction variables: $\mathrm{BS}, \mathrm{BC}, \mathrm{BSC}$, and BGD and control variable FS reviewed the weak ability to predict profitability proxy - return on equity and accounts for about $5 \%$ of the cross sectional variations in the dependent variable of ROE. This implies that the remaining $95 \%$ variation in ROE cannot be explained because it is related to other variables which are not depicted in the model. The implication is that there may be number of variables which can have an impact on profitability of food and beverages firms that need to be studied. Durbin - Watson statistic test was also carried out to check the auto 
correction among the independent variables. The Durbin - Watson statistic ranges in value from $0-4$. A value near 2 indicates non-auto correlation. The Durbin - Watson statistic of 2.323135 signifies the absence of auto correlation. In this result, the interpretation for level of significance is based on 5 per cent (0.05) critical value. Thus, BS has $\mathrm{t}$ - statistic value of 1.834223 with an associated probability of 0.0702 reveals that there is a positive and insignificant relationship between board size and return on equity. Also, the reported regression coefficient values of 4.945574 for BS holds that a unit increase in BS will lead to about 4.95 units increase in ROE with 7 per cent probability level. The reported $\mathrm{t}$ - statistic value of -0.312521 for $\mathrm{BC}$ has probability value of 0.7554 that is insignificant for the 5\% (0.05) significance level to lead to the conclusion that board composition has a negative and weak relationship with return on equity. Further, the coefficient value of -0.669708 for BC means that a unit increase in $\mathrm{BC}$ will lead to about 0.67 units decrease in ROE with 75.54 per cent probability level. Also, the $t-$ statistics value of -1.322723 associated with the reported probability value of 0.1896 for BSC indicates negative and insignificant relationship with ROE, and as such, the regression coefficient value of -4.722703 for BSC implies that a unit increase in BSC will bring about 4.72 units decrease in ROE with 18.96 per cent probability level. In addition, the reported $t-$ statistics of 1.512930 and associated probability of 0.1341 for BGD show a positive and statistically insignificant relationship with return on equity to suggest that the observed data is inconsistent with the assumption that the null hypothesis is true, and in this respect, the regression coefficient value of 4.761343 for BGD means that a unit increase in BGD will lead to about 5 units increase in ROE with 13.41 per cent probability level. Subsequently, the $\mathrm{t}-$ statistics value of -0.078709 and probability value of 0.9375 for FS reveal that there is a negative and weak relationship between FS and ROE, and the reported regression coefficient value of -1.99 for FS holds that a unit decrease in FS will bring about 1.99 units increase in ROE. Since the firm size unit in naira is in one billion ( 1 billion) and the unit of return on equity is in one naira ( 1 ), it could mean that billion decrease in firm size as measured by total assets will lead to 1.99 increase in return on equity of the listed food and beverages firm in Nigeria.

Table 3.2 shows the result of the pooled OLS regression estimates for prediction model 2 . The result is useful in explaining the empirical association between dependent variable (nets assets per share, NAPS) and the independent and control variables. $\mathrm{R}$-squared is 0.191389 ; this implies that 19 per cent of the variations in NAPS were insignificantly explained by the variation in the independent and control variables. The remaining $81 \%$ is explained by other factors outside the independent variables in the model. The reported Durbin - Watson statistics value of 2.014231 signifies the absence of auto correlation. The interpretation for significance is based on 5 per cent $(0.05)$ critical value. Thus, based on the result, BS with robust reported $t$ - statistic value of 4.038630 and the corresponding probability value of 0.0001 is beyond the likelihood of chance. It reveals that there is a positive and statistically significant relationship between BS and NAPS, and as such, the regression coefficient value of 50.01826 for BS suggests that a unit increase in BS will lead to about 50 units increase in net assets per share (NAPS) with 0 per cent probability level. The reported t-statistics value of 0.355852 and the associated probability value of 0.7229 for $\mathrm{BC}$ indicate that there is a positive and statistically insignificant relationship between $\mathrm{BC}$ and NAPS, also, the regression coefficient value of 3.5021719 for BC holds that a unit increase in BC will cause about 3.5 units increase in NAPS with 72.29 per cent probability level. The reported t-statistics value of -2.556449 and the associated probability value of 0.0124 for BSC show negative and statistically insignificant association between BSC and NAPS; in this respect, the reported regression coefficient value of -41.92652 for BSC holds that a unit increase in BSC will cause about 41.93 units decrease in NAPS with 1.24 per cent probability level. BGD has reported t-statistic value of 2.822992 and corresponding probability value of 0.0060 , signifying that positive and statistically significant relationship between board gender diversity (BGD) and net assets per share (NAPS); in this regard, the reported regression coefficient value of 40.80849 holds that a unit increase in BGD will lead to 40 units increase in NAPS with 0.6 per cent probability level. FS has reported t-statistic value of -0.841210 with associated probability value of 0.4026 indicating that there is a negative and statistically insignificant relationship between FS and NAPS, and the reported regression coefficient value of -9.78 for FS reveals that a unit increase in FS will lead to 9.78 units decrease in NAPS. Since the firm size unit in naira is equal to one billion (N1billion) and the unit of NAPS is in one naira ( $\mathrm{N} 1$ ), it means that 1 billion increase in FS as measured by total assets will lead to $\$ .78$ decrease in net assets per share of the listed food and beverages firms in Nigeria.

\subsubsection{Results of Test of Hypotheses}

\section{Statement of Hypothesis One}

Ho1: The size of the Board of Directors has negative relationship with profitability of food and beverages firms in Nigeria.

$\mathrm{H}_{\mathrm{A}} 1$ : The size of the Board of Directors has positive relationship with profitability of food and beverages firms in Nigeria.

To test this hypothesis, two prediction models from the results of the regression estimates were used. This is as shown in appendix 3 comprising of table 3.1 to table 3.2 and as summarized in appendix 4. Prediction model 1 is used to test whether the size of the board of directors has a positive relationship with profitability as measured by return on equity which shows the reported $t$ - statistics value of 1.834223 and associated probability value of 
0.0702 at the $5 \%(0.05)$ level of significance and it implies that there is a positive but statistically insignificant relationship between board size and return on equity. Therefore, null hypothesis (Ho1) is rejected, while, the alternative hypothesis is accepted. Prediction model 2 tests whether the size of the board of directors has a positive relationship with profitability as measured by net assets per share. The reported $t$ - statistics value of 4.038630 and the associated probability value of 0.0001 at $5 \%(0.05)$ level of significance show that there is a positive and statistically significant relationship between board size and net assets per share. Therefore, null hypothesis is rejected. In summary, it is safe to conclude that the size of the board of directors has a positive relationship with profitability of food and beverages firms in Nigeria.

\section{Statement of Hypothesis Two}

Ho2: The board composition is negatively associated with profitability of food and beverages firms in Nigeria. $\mathrm{H}_{\mathrm{A}}$ 2: The board composition is positively associated with profitability of food and beverages firms in Nigeria. To test this hypothesis, two prediction models from the results of the regression estimates were used. This is as shown in appendix 3 containing table 3.1 to table 3.2 and as summarized in table 4 of appendix 4 . Prediction model 1 is used to test whether board composition is positively associated with profitability as measured by return on equity. The reported $t$ - statistics value of -0.312521 with corresponding probability value of 0.7554 and the $5 \%$ (0.05) level of significance shows that there is a negative but statistically insignificant association between board composition and return on equity. Therefore, null hypothesis (Ho2) is accepted. Prediction model 2 is used to test whether board composition is positively associated with profitability as measured by net assets per share. The value of $t$ - statistics obtained is 0.355852 with the corresponding probability value of 0.7229 and at the $5 \%(0.05)$ level of significance. This shows that there is positive but statistically insignificant association between board composition and net assets per share. Therefore, null hypothesis (Ho2) is rejected, while, alternative hypothesis $\left(\mathrm{H}_{\mathrm{A}} 2\right)$ is accepted. In summary, the results of the association between board composition and profitability are mixed. Thus, it is safe to settle that the association between board composition and profitability of food and beverages firms in Nigeria is inconclusive.

\section{Statement of Hypothesis Three}

Ho3: Board skills and competence has negative relationship with profitability of food and beverages firms in Nigeria.

$\mathrm{H}_{\mathrm{A}} 3$ : Board skills and competence has positive relationship with profitability of food and beverages firms in Nigeria.

To test this hypothesis, two prediction models from the results of the regression estimates were used. This is as shown in appendix 3 containing table 3.1 to table 3.2 and as summarized in table 4 of appendix 4 . Prediction model 1 is used to test whether board skills and competence has a positive relationship with profitability as measured by return on equity. The value of $t-$ statistics obtained is -1.322723 with associated probability value of 0.1896 and the $5 \%(0.05)$ level of significance indicates that there is negative and statistically insignificant relationship between board skills and competence and return on equity. Hence, null hypothesis (Ho3) is accepted. Prediction model 2 is employed to test whether board skills and competence has a positive relationship with profitability as measured by net assets per share. The obtained $t-$ statistics value of -2.556449 with associated probability value of 0.0124 and the $5 \%(0.05)$ level of significance shows negative but statistically significant relationship between board skills and competence and net assets per share. Thus, it is clearly convenient to conclude that board skills and competence has negative relationship with profitability of food and beverages firms in Nigeria.

\section{Statement of Hypothesis Four}

Ho4: There is negative correlation between board gender diversity and profitability of food and beverages firms in Nigeria.

$\mathrm{H}_{\mathrm{A}} 4$ : There is positive correlation between board gender diversity and profitability of food and beverages firms in Nigeria.

To test this hypothesis, two prediction models from the results of the regression estimates were used. This is as shown in appendix 3 containing table 3.1 to table 3.2 and as summarized in table 4 of appendix 4 . Prediction model 1 is employed to test whether there is positive correlation between board gender diversity and return on equity. The reported $\mathrm{t}$ - statistics value of 1.512930 with associated probability value of 0.1341 and the $5 \%(0.05)$ level of significance indicates positive but statistically insignificant correlation between board gender diversity and return on equity. Hence, null hypothesis (Ho4) is rejected. Prediction model 2 is used to test whether there is a positive correlation between board gender diversity and net assets per share. The obtained $\mathrm{t}-$ statistics value of 2.822992 with associated probability value of 0.0060 and the $5 \%(0.05)$ level of significance shows positive and statistically significant correlation between board gender diversity and net assets per share. Therefore, null hypothesis (Ho4) is rejected. Thus, it is safe to conclude that there is positive correlation between board gender diversity and profitability of food and beverages firms in Nigeria. 


\subsection{Discussion of the Empirical Findings}

This section discusses the empirical results from the panel regression estimates based on the pooled Ordinary Least Squares (OLS) reported in the appendix 3 and summarized in appendix 4. Considerably, the estimated coefficient of the size of the board of directors turns out to a positive but statistically insignificantly related to return on equity and similarly it shows a positive and strongly significant with net assets per share. Hence, the results are sufficient to submit that a positive relationship exists between size of board of directors and profitability of food and beverages firms in Nigeria. This implies that the larger the size of the board of directors, the higher the profitability of the companies. The rationale for a positive relationship between board size and profitability indicators - return on equity and net assets per share may be because directors own part of the company's equity (Okougbo, 2011:61). It is therefore plausible to argue that as the board increases in size, the newly appointed directors are allocated shares leading to both increase in equity and monitoring function that will reduce operational costs while profit increases, thereby improving the amount of equity. The positive relationship of board size with the profitability surrogates - ROE and NAPS advocates that companies' board of directors with large size enjoy higher profit compared to the firms' board of directors with small board size. This finding suggests that larger board of directors take advantage of their number in ensuring effective corporate governance process and this leads to increase production and reduction of operating expenses. This is in support of resource dependency theory. The proponents of large board size are of the view that it provides an increase pool of experience, knowledge, skills and diversity at their disposal to make better decisions and also capable of reducing the dominance of an overbearing MD/CEO and hence puts necessary checks and balances (Forbes and Milliken, 1991; Pfeffer, 1983; Pearce and Zahra, 1992; Goodstein, et al. 1994). However, this finding is inconsistent with agency, shareholder value and value-synergy approaches.

Board composition reported negative and statistically insignificant association with return on equity and positive but statistically insignificant association with net assets per share. The results obtained show a mixed and inconclusive relationship between board composition and firm profitability. This implies that an independent board may help or may not help to improve the level of profitability of the listed food and beverages firms in Nigeria. The result of negative association of board composition with profitability surrogate - return on equity suggests that improved profitability of the food and beverages firms in Nigeria is not dependent on increasing the proportion of non-executive directors serving on the board of the companies. More so, the result implies that when there are more external board members serving on the board, return on equity of the food and beverages firms in Nigeria tends to worse off. This result is not in support of the 2003, 2011 and 2015 codes of corporate governance in Nigeria, agency theory and shareholder value theory that believe that effectiveness of board of directors can be enhanced by increasing the proportion of outside directors serving on the board. Instead, the result is in support of stewardship theory and value-synergy approach that seek for less proportion of non-executive directors serving on the board, particularly, the value-synergy approach advocates for increase in the size of management team, instead. This result is consistent with Siladi (2006) and Tornyeva and Wereko (2012) view that board composition is ineffective because non-executive directors are too busy with other commitments and Bosch (1995) believes that they put less time and less than average efforts in discharging their duties; they can create problems of information and have limited scope (White, 2013; Baysinger and Hoskisson, 1990). The result is also consistent with findings of Agrawal and Knoeber (1996) who suggest that boards expanded for political reasons often result in too many outsiders on the board, which does not help performance. However, the result of positive association between board composition and profitability surrogate - net assets per share suggests that improved profitability of the food and beverages firms in Nigeria depends on increasing the proportion of non-executive directors serving on the board of the companies. This supports the view that independent non-executive directors are crucial to the growth and the survival of firms and according to Dehaene, et al. (2001); Connelly and Limpaphayon, (2004); Uadiale (2010), the larger proportion of board composition can positively influence firm profitability and encourage more intensive audits (O'Sullivan, 2000). Nonetheless, it could therefore be that the negative empirical result the board composition has with return on equity of the sample companies could be due to ineffective board communication and information flow; poor induction, training and development programmes for the board members; high rate of multiple directorships among the independent non-executive directors; appointing two or more members of nonexecutive directors from the same family to sit on the board at the same time; not seeking and obtaining external professional advice in the discharge of their responsibilities; inability of the company management to provide necessary information in a timely manner to the members of independent non-executive directors; excessive familiarity of the members of independent non-executive directors with the senior management/CEO - which is a threat to their independence; not including a sizeable number of independent non-executive directors in the risk management committee; flaws in the appointment process of independent directors; ineffective implementations of the recommendations of the independent non-executive directors by the boards; independent non-executive directors having significant ownership stake in the company; poor attendance of board committee meetings due to multiple directorships or other outside commitments; mismatching of skills and competence; ineffective performance evaluation of the boards and individual directors; appointment of independent non-executive directors 
without considering experience, specialist knowledge and personal qualities; non-executive directors not involving in constructive challenge and contribution to the development of the strategy of the company; not having unfettered access to the key officers of the company or management team.

Board skills and competence reported negative and statistically insignificant relationship with return on equity and net assets per share. The results clearly indicate negative relationship with profitability of food and beverages firms in Nigeria. This result is inconsistent with value-synergy approach, stakeholder theory and resource dependence that believe that board members are embodiments of value, expertise, knowledge and experience needed to make firms perform better; and help board to challenge conventional thinking and question current practices (Coulson - Thomas, 2007). More so, the negative results contradicted the invisible power of skills and competence as a critical asset in generating high returns and increase profits from the assets base of the food and beverages firms in Nigeria. But, this does not mean that board skills and competence is not must possess dire advantage for higher performance of firm. According to Power (1991), it could be due to the occupational and professional affiliations of highly qualified directors which may increase agency behaviour. Ideally, if directors and managers should demonstrate the utmost good faith and integrity required of them, then higher skill levels should bring about higher corporate performance (Tornyeva and Wereko, 2012). Further, the negative relationship is not due to the fact that skills and competence is not the pillar for enhancing board effectiveness for high firm performance, but it might be as a result of the inability of the directors to personally maintain and enhance their competence, as well as failure to identify and address gaps in their own and the board's collective competence. It might also be that the boards' nomination committees of food and beverages firms in Nigeria were not able to recruit and select the right mix of skills, capabilities, experiences and attitudes to deliver the right outcomes to stakeholders. More so, other likely causes to the negative relationship include: inability to take proactively individual and collective responsibility for ensuring that market knowledge, technical knowledge, and professional skills of directors are maintained; failure to remain aware of economic conditions, industry developments and changes in the company's strategic direction; board comprising of inappropriate diverse group of directors that are not able to possess collectively the technical skills, conceptual skills, human relations skills and attitudes require to deliver the best outcomes for stakeholders; inability of the board to exercise fully inclusive leadership approach; failure of the board as a group to maintain up to date competency in its areas of supervision through continuing professional developments, consultation, and other procedures in conformance with current standards of industry; failure of the directors as a group to translate their competencies into economic reality; mismatching of skills and competence; lack of understanding of the power of effective board skills and competence as a prime factor that contributes to better board performance; appointing directors on the board without a clear understanding of the specific job they are supposed to perform and without receiving any written information about their roles, responsibilities, expectations and accountabilities; appointing directors to serve for their influence or affluence rather than on the basis of predetermined competencies; poor performance of the board chairman in ensuring that the board and its committees are composed of the relevant skills, competencies and desired experience.

Board gender diversity is used as proxy for board diversity. It reported positive but weak correlation with profitability indicators - return on equity, as well as positive and statistically significant with net assets per share. This indicates that a positive relationship does exist between board gender diversity and profitability of food and beverages firms in Nigeria. The positive relationship of board gender with profitability implies that Nigerian food and beverages firms with higher proportion of women directors on the board are more committed to ensuring for improved performance of the firm and that larger number of women directors serving on the board will ensure effective corporate governance process that will enhance reduction of operating expenses to improve profitability. This is as it will bring new ideas and different perspectives to the firm as well as the company will benefit from more diversity of thought, commitment and purpose. The positive and weak relationship could also mean that the presence of women as directors on the boards of food and beverages firms in Nigeria will help to increase the sector profitability. The positive result is supported by different theoretical perspectives: shareholder theory, agency theory, resource dependency theory, political theory and value-synergy approach that believe that diversity opens the arms of linkage, value, transparency, independence and accountability which are necessary for better performance. Many authors and previous studies have supported board gender diversity (Langevoort, 2011; Luckerath - Rovers, 2011; SCGN, 2014; Ijas, 2012; Valsan, 2013; Erhardt, et al. 2003; Catalyst, 2007; McKinsey, 2007).

Finally, the firm size comes out with a negative and statistically insignificant in all statistic panel models with profitability surrogates - ROE and NAPS indicating that firm size as measured by total assets has negative and weak relationship with profitability of food and beverages firms in Nigeria. The results obtained for firm size do not let the investigator conclude that firm size has an influence on firm profitability. It shows that Nigerian food and beverages firms with high amount of non-current assets do not have any relationship that could affect profitability. It might also be that the non-current assets of the firms are weak and old to put the companies into sustainable path of success and growth. Consequently, it will generate heavy operating expenses and inefficiency which in turn will lead to significant erosion of revenue and at last to slim profitability. The result is consistent 
with previous studies (Goddard, Tavakoli, and Wilson, 2005; Nunes and Serrasquerro, 2008). However, it contradicted with some other investigations that found that firm size as measured by total assets has positive relationship with profitability (Okougbo, 2011; Lee, 2009; Omondi and Muturi, 2013; Babalola, 2013).

\subsection{SUMMARY, CONCLUSION AND RECOMMENDATIONS \\ 5.1.0 Findings of the Study}

This study was based on qualitative and quantitative approaches to research. Therefore, findings made were classified into two: theoretical findings and empirical findings.

\subsubsection{Summary of Theoretical Findings}

Having conducted a laparotomy of codes of corporate governance in Nigeria, its regulatory framework, and examination of different theoretical perspectives and models, certain theoretical findings on the nature of relationship between corporate governance and profitability of food and beverages firms in Nigeria are summarized as follows:

1. The examination of size of the board of directors of the sample companies ranging from the minimum number of 7 to maximum of 14 directors suggests that the food and beverages firms in Nigeria prefer large size of boards to small size of board. The implication is that large boards increase the firm's profitability more than small boards. The view of large board is consistent with the resource dependency theory that proposes that boards are sources of linkages of the firms. This view of resource dependency theory about the board is also in agreement with the provisions of codes of corporate governance in Nigeria which allows large board size. However, the view of large board size is inconsistent with agency theory, shareholder value theory and value-synergy approaches, which suggest that involvement of large board size, will increase agency cost and make decision process difficult, lead to waste of much energy and time and may allow board to be manipulated by management.

2. As regards to board composition of the sample companies, the independent director composition ranges from the minimum of $46 \%$ to the maximum of $86 \%$ and on average of $70 \%$ shows that food and beverages firms in Nigeria have an adequate number of outside directors serving on their boards. However, this could not have resulted into better performance measures in the industry. Suffice this to say that, high board composition does not necessarily imply increase in profitability of food and beverages firms in Nigeria; as chances of the non-executive directors not to be efficient are high. Therefore, a higher proportion of independent directors do not guarantee increase in firm profitability in the sample companies. Whereas, the agency theory, shareholder value theory and the codes of corporate governance in Nigeria all assume that the more number of independent directors a firm will have the better the profitability of the firm.

3. The appointment of directors with only educational degree and/or professional qualifications on the board of directors of the sample companies could not give rise to improved profitability in the two models. The results could not support resource dependency theory, value-synergy approach, stakeholder theory and the code of corporate governance in Nigeria that give credence for recruitment of competent, knowledgeable and experience persons as directors.

4. Even though the proportion of women directors serving on the board of directors of food and beverages firms in Nigeria is very small as it ranges from the minimum proportion of 0 per cent to maximum of 29 per cent and on average of 6 per cent, it does appear that board gender diversity helps to improve the profitability level of the sample companies. The implication is that the more female directors that are appointed to serve on the board of directors of food and beverages firms in Nigeria, the better the profitability of the firms. This positive relationship result is in support of the provisions of code of corporate governance in Nigeria that encourages for selection of board members on the basis of diversity. This is also consistent with agency, stakeholder, resource dependency, political and value-synergy perspectives of corporate governance.

\subsubsection{Summary of Empirical Findings}

The study, in addition to theoretical evidence, provides empirical support of the relationship between corporate governance and profitability of firms as summarized below:

1. Board size has a positive and insignificant relationship with return on equity and statistically significantly positive relationship with net assets per share of food and beverages firms in Nigeria implying that board size influences the profitability parameters in the firms; as such, the larger the board size, the higher the firm profitability. This is consistent with the empirical findings of previous studies (Kashif, 2008; Zubaidah, Nurmala, and Kamaruzaman, 2009; Tornyeva and Wereko, 2012; Okougbo, 2011; Mutalib, 2012; Babatunde and Olaniran, 2009; Tanko and Kolawole, 2007; Uadiale, 2010; Dabor, et al. 2015).

2. Empirical results reveal that board composition has negative and statistically insignificant relationship with return on equity and by implication increase in number of independent non-executive directors serving on the board of food and beverages firms in Nigeria will reduce the profitability of the firms. The 
negative relationship between corporate management and profitability in this study has the support of previous studies (Tornyeva and Wereko, 2012; Dalton, et al. 1998; Dabor, et al. 2015; Oluwafemi, et al. 2013; Babatunde and Olaniran, 2009). However, board composition shows a positive but statistically insignificant association with net assets per share. This indicates that increase in the number of nonexecutive directors will lead to higher net assets per share of food and beverages firms in Nigeria; this result is consistent with agency and shareholder theories.

3. Furthermore, the study observes that the relationships between board skills and competence with profitability indexes - return on equity and net assets per share show negative and statistically insignificant results. This result is inconsistent with all theories and codes of corporate governance.

4. The study equally observes that board diversity proxy - board gender diversity does have positive but statistically insignificant correlation with return on equity as well as strong positive correlation with net assets per share. The implication is that the larger the number of female directors serving on the board of food and beverages firms in Nigeria, the better the performance of those profitability surrogates. This finding is consistent with previous studies (Erhardt, et al. 2003; Bathula, 2008; Rose, 2007; Chiang, 2005; Luckerath-Rovers, 2011).

5. Finally, the regression results show that firm size as measured by total assets has negative and statistically insignificant relationship with profitability of food and beverages firms in Nigeria. This is consistent with the findings of previous studies (Goddard, Tavakoli, and Wilson, 2005; Nunes and Serrasqueiro, 2008).

\subsection{Limitations of the Study}

Like most research efforts the current study has some limitations that provide opportunities for future researchers to address.

1. Corporate governance is a vast concept and is difficult to measure with objectivity and hence measure used in this study may be subjective and not a comprehensive measure.

2. A limited number of corporate governance mechanisms were examined. The study could not investigate other corporate governance characteristics due to data constraints, time and space, among other factors. Consequently, important elements such as insider ownership, board committees, ownership structure, Chairman/CEO duality, CEO's remuneration disclosure and frequency of board meetings, among other factors could not be included. Future researchers may benefit from including additional corporate governance mechanisms.

3. The study focus corporate governance mechanisms mainly on board structure without bringing elements of board process in the investigation. Future researchers may benefit from focusing corporate governance mechanisms on board process characteristics.

4. More so, profitability of a firm is influenced by more factors than just good corporate governance. Issues of social, legal, economic and the political environment are equally important. In addition, other various control variables such as firm's age, growth, leverage, risk, Research and Development (R\&D), industry, etc. have not been incorporated in the analysis. More so, the firm size measurement considered was total assets. Further study should consider number of employees and volume of sales. It is therefore suggested that future research should consider some of these factors exploring the impact of corporate governance on firm profitability.

5. The current study is limited in the scope because it focused mainly on finding the relationship of corporate governance and profitability of listed foods and beverages firms in Nigeria. This may possibly limit a wide applicability of the study to other companies not listed on the Nigerian Stock Exchange. Also, the sample survey is companies in Nigeria and may not be applicable to other country context.

6. Also, the study considered only one sector of listed firms in Nigeria. Future studies can incorporate different sectors and can also find differences in those sectors related to corporate governance structures and their relationship with firm profitability.

7. Market-based measures such as share prices, stock returns, and market value of firm, among others have been ignored in place of accounting based measures.

8. The research considered non-executive directors and independent directors as one indicator in determining board composition. Whereas the code 2003 and 2011 SEC provides for them differently. Any further research that separates board composition in terms of non-executive directors and independent directors would add more benefits to the literature.

9. The study gave all the theories in corporate governance with equal chance to their views, and as such, did not consider any particular one as the main focus. Consequently, the investigation could not expect any signs for the regression coefficients of the explanatory variables. Future researchers may benefit from focusing corporate governance indicators on a particular theory and ascribes signs to the regression coefficients based on the view of the theory.

10. Finally, the research did examine firm's performance only from profitability or financial performance 
perspective. Future research would benefit from the examination of performance from non-financial perspective and of the relationship between corporate governance characteristics and performance across the firms.

Despite the limitations, it is hoped that this study would provide an important contribution to the corpus of corporate governance literature.

\subsection{Practical Implications of the Study}

The results from the study show that the food and beverages firms in Nigeria have great opportunities for growth and can generate high profitability to meet the interests of all their stakeholders. It also indicates that the industry is well positioned to support the economic growth and development of the country. And for Nigeria to keep its Gross Domestic Products (GDP) increasing, this sector of the economy must be strongly encouraged to adopt good corporate governance practice that would enable it generates more resources to create more employment opportunities, support in corporate social responsibility, boost agricultural activities, improve capital markets, make robust the banking sector, make the industry globally competitive and attractive, and take the sector to the next level by prompt payment of attractive dividends to shareholders, with high net assets per share and return on equity.

\subsection{Conclusion}

It has been said that, "the cornerstone to corporate governance efforts lies in one basic policy objective: selling the concept to the business community. We have to convince businesses that better corporate governance serves them." Effective and robust corporate governance system is an essential feature of successful companies. Against this background of examining the relationship between corporate governance and profitability, it is very much the purpose of this study to let in some fresh view on the role of corporate management in firm profitability and to make recommendations to enhance its effectiveness towards raising the bar for superior corporate performance. As a matter of fact, the effectiveness and efficiency of any company is a function of the quality of corporate government adopted in the organization. Adoption of good corporate governance practices enhances transparency of company's operations, ensures accountability, improves risk management and increases firm's profitability. More so, it promotes cooperation among the stakeholders of the firm, and most importantly, aligns the interest of shareholders with that of the managers, and opens the gate for corporate success. From this study, the conceptual and empirical findings hold that on average, corporate governance has positive relationship with profitability of food and beverages firms in Nigeria. Most of the corporate governance characteristics of board size, board composition and board gender diversity employed in the study reveal positive correlation with the profitability of food and beverages firms in Nigeria, in exception of the board skill and competence. Despite this result, the findings show that the food and beverages firms must have large board size with wide range of diversity and gender consideration, and must also be independent from the management of the company as well as galvanized with right skills and competence to bring the desired turn around in the companies. This would help to give the board the strategic control and direction. Also, this research work, "promotes acceptance of corporate governance, no longer as something of 'borrowed' discipline, but as a way of running enterprises that takes sensitive account of the needs and imperatives of corporate practice in Nigeria." Finally, corporate governance and profitability are the twilight zone of a firm. Together, they establish system of rules and measurement of performances, and ensure continuous coexistence of all interest groups. Suffice this to say that, corporate governance is not only a technique. It is also a hope. It is the hope that common ground and common good can be found, forged and expressed between stakeholders and between economies, despite their differences in corporate objectives. It is the hope that common appropriate behaviour can be found to restore public confidence of corporations from action plans and internal controls to performance measurement and corporate disclosure of every organization. This hope is anchored on persons who are charged with the sole responsibility of keeping the flagship of corporations strongly fluttering. The hope that, guided by reason and aware of the fragility of corporate life, "human beings are capable of valuing what brings them together, rather than what keeps them apart". Truly, it is the hope that strikes "the balance between economic and social goals', and aligns 'as nearly as possible the interests of individuals, corporations and society'. It is the hope of economic justice, fairness and equity among the stakeholders. Be that as it may, "this hope, we all know it, this hope is not self-fulfilling". It will only come true if we have the strength for 'intellectual honesty', and sometimes also the uncommon courage and humility, to make possible, and to oppose and reconcile the conflicting self-imposing interests of stakeholders that too often and too easily puts our corporate goals asleep. Lest it shall be late, we urge every legitimate interest holder to keep the hope determinedly alive, viable, vibrant and growing by standing for good corporate governance that serves as a system of checks and balances for a better firm profitability at all times.

\subsection{Recommendations}

The submissions made in this study are based on the major research findings in the course of establishing the 
relationship between corporate governance and profitability of food and beverages firms in Nigeria. They are highlighted as follows:

1. This study has confirmed that corporate governance has a linear relationship with firm profitability. Therefore, the issues of corporate governance should be considered as important as profit making since it is a key factor in maximizing shareholders and other stakeholders' value. As a matter of fact, nomination and governance committee should be composed of as provided by section 8.12.4 of the 2015 NCCG as well as ensure that as provided by section 8.12 .5 of the $2015 \mathrm{NCCG}$, that a separate section of the annual report should be used to describe the work of the committee, including the process it uses in relation to board appointments.

2. The findings made in this study have clearly shown that profitability parameters are linked with good corporate governance. Therefore, any fall in profitability should be considered as a dangerous signal and the corporate board should investigate into it immediately without compromise.

3. The finding from the study also indicates that the food and beverages firms in Nigeria have strength in large board size as increase in board size will increase their key profitability ratios. Therefore, the board should dwell on this by appointing more resourceful persons on the board and considering majorly diversity, knowledge and competence as well as 'intellectual honesty' of the persons.

4. The result on the board composition suggests that the food and beverages firms in Nigeria should reduce the proportion of board composition as well as review the process of enhancing the effectiveness of nonexecutive directors on their boards. Also, the negative impact of independent directors on the profitability of the firms could also be addressed by improving board education, ensuring more communication and information flow effectiveness, not basing appointment of independent non-executive directors on family ties, political associates, or on other subjective approach. The firms should also adopt the provision of Derek Higg's Report of mandating any person prior to appointment, potential new non-executive directors to carry out due diligence on the board and on the company to satisfy themselves that they have the knowledge, skills, experience and time to make a positive contribution to the board.

5. The result of board gender diversity also suggest that the boards of food and beverages firm should endeavour to increase the quota of women directors serving on the board as this will help to boost the profitability potency of the companies and ensure operating efficiency, improved quality product and pricing efficiency.

6. Board of food and beverages firms should go extra-mile in providing regular educational training and development to improve the skills and competence of not just the board members, also the management team and the rest of the workforce. This is necessary to reaffirm the uniqueness of the industry through building mind-sets that can sustain the industry; provide innovation and creativity required to continuously rebranding the business products, ensuring price efficiency, improved productivity and motivation for tireless efforts. Developing their skills and competence has become very necessary because innovation is a product of education and education reboots the fire of innovation; and whenever a person catches the fire of innovation, a new product is borne and the existing ones become rebranded.

7. The Financial Reporting Council of Nigeria in collaboration with the Securities of Exchange Commission and Nigerian Stock Exchange should introduce the use of Corporate Governance Indices (CGIs) to measure the level of Corporate Governance Compliance by public companies in Nigeria.

8. The idea of issuing external auditors' certificate on corporate governance as it is applicable in India and other countries of the world should be emulated by the country's code of corporate governance regulator. This concept should be introduced to the publicly listed companies in Nigeria; as a mandatory requirement that should form part of every company's annual reports and accounts. The external auditors should be required to give a certificate on the compliance of corporate governance provisions for public companies.

9. There is need to develop a meaningful evaluation tool for regular appraisal of boards of directors as a whole and individual directors. This would help to create helpful credibility and acceptance for the corporate governance practice in the Nigerian firms. The modality and the performance of the evaluation should be communicated to the investors during the Annual General Meeting and formed part of the companies' Annual Reports and Accounts. Independent Appraisal body should be allowed to carry out the exercise. Thus, there is need to develop quantitative appraisal model for determining board of directors and individual director effectiveness.

10. Enforceability and sanctions provisions made in the exposure draft of 2015 National Code of Corporate Governance for private sectors should be well defined. Section 37 of the 2015 NCCG should categorically state the person(s) that can pursue for the enforceability of the National code. Also, it should clearly spell out the applicable sanctions against any violator of the code. This will help make the code to be taken more serious and increase the level of its compliance.

11. The Financial Reporting Council of Nigeria should provide for the minimum required educational qualifications, skills, knowledge and experience for an individual to be appointed into the board of a 
company. This will serve as a standard criterion for the appointment and evaluation of a person on the board. Statutory and regulatory bodies should ensure that at least quoted firms appoint directors with threshold competency on the boards. The individual director should be able to demonstrate inclusive leadership acumen of transparency, empowerment, accountability, courage and humility (TEACH).

\subsection{Suggestions for Further Research}

In the course of the study, areas that further research could be conducted were opened. For more validity of findings, the other non-financial sectors of the economy like pharmaceutical, personal and household; transportation; hotels and lodges, etc. should be included in a similar study; as well as testing other corporate governance characteristics other than the ones used in this study. Also, market based performance indicators can be explained rather than using only accounting based measures. More so, all the areas identified as limitations of this study in chapter five provided promising avenue for further studies. In general, there is need for an empirical study to be conducted on corporate governance using board process mechanisms and profitability. Other areas that need further research include: Investigating the applicability of value-synergy perspective in corporate governance and performance; Code of Corporate Governance Compliance and Performance in Nigeria as well as extending this empirical study to public sector organizations in Nigeria.

\section{REFERENCE}

Adams, R. and Mehran, H. (2003). “Is Corporate Governance Different for Bank Holding Companies?” Economic Policy Review, 9, pp.123 - 142.

Abdullahi, H. and Valentine, B. (2009). Fundamental and Ethics Theories of Corporate Governance. Middle Eastern Finance and Economics, pp. 88 - 96.

Abdullah, S.N. (2004). "Board Composition, CEO Duality and performance among Malaysian Listed Companies." Corporate Governance, 4, 4, pp.47-61.

Abor, and Biekpe, (2008). Does Corporate Governance Affect the Capital Structure Decision of Ghanaian SMES? University of Stennenbosch, Business School, South Africa.

Adedeji, E.A. (2014). "Interrelationship of Capitalisation, Market Power and Profitability in Selected Food And Beverages Firms in Nigeria." Research Journal of Finance and Accounting, Vol.5, No. 19, pp. 31-38. Available on: http://www.iiste.org

Adegbite, E. (2012). “Corporate Governance Regulation in Nigeria.” Corporate Governance, vol.12 (2), pp.257276, Emerald Group Publishing Ltd.

Adesanya, M. O. and Oloyede, E. O. (1981). Business Law in Nigeria. Lagos: University of Lagos And London: Evans Brothers Limited.

Adeyemi, B. (2013). The Role of the Company Secretary in Corporate Governance Compliance. Business Day Newspaper, May 6. Available on: Businessdayonline.com

Adusei, M. (2011). "Board Structure and Bank Performance in Ghana.” Journal of Money Investment and Banking, 199(2), pp.72-84

Aggarwal, P. (2013a). "Impact of Corporate Governance on Corporate Financial Performance." IOSR Journal of Business and Management (IOSR - JBM), 13(3), pp. 1-5.

(2013b). "Corporate Governance and Corporate Profitability: Are They Related? - A Study In Indian Context." International Journal of Scientific and Research Publications, vol.3, Issue 12, December, pp. 1- 8. Available on: www.ijsrp.org

Agrawal, A. and Knoeber, C.R. (1996). "Firm Performance and Mechanism to Control: Agency Problems Between Managers and Shareholders" Journal of Financial and Quantitative Analysis, Vol.31, pp.377 - 397.

Ajagbe, A.M. and Ismail, K. (2014). "Factors Influencing Venture Capital Assessment of High Growth Companies in Malaysia." International Journal of Entrepreneurship and Small Business, 21(4), pp.457 - 494.

Ajagbe, A.M., Oluyinka, S. and Long, C.S. (2011). "The Relationships between Strategic Planning and the Effectiveness of Marketing Operations." International Journal of Innovation, Management and Technology, 2(5), pp.390-396.

Ajanthan, A. (2013). Impact of Corporate Governance Practices on Firm Capital Structure and Profitability: A Study of Selected Hotels and Restaurant Companies in Sri Lanka. Research Journal of Finance and Accounting, Vol.4 No.10, pp. 115-126. Retrieved from: www.iiste.org

Ajayi,O. (2011). The Code of Corporate Governance for Public Companies in Nigeria 2011: A Primer. Available on: http://www.olaniwunajayi.com On March 27, 2015.

Akharayi, C. (2005). "The Establishment of Audit Committees in the Public Sector - Necessity for Financial Oversight.” The Nigerian Accountant, Vol.48, No. 2, April/June, pp. 35-39.

Akpan, E.O. and Amran, N.A. (2014). "Board Characteristics and Company Performance: Evidence from Nigeria." Journal of Finance and Accounting, June 20, vol.2, No.3, pp.81 - 89. Available at: http://www.sciencepublishinggroup.com 
Aljifri, K. and Moustafa, M. (2007). "The Impact of Corporate Governance Mechanisms on the Performance of UAE Firms: An Empirical Analysis.” Journal of Economics and Administrative Sciences, 23(2), pp.7193.

Almajali, A.Y., Alamro, S.A. and Al-soub, Y.Z. (2012). Factors Affecting the Financial Performance of Jordanian Insurance Companies Listed at Amman Stock Exchange. Journal of Management Research, 4(2), pp. 266-289.

Amran, N.A. (2011). "Corporate Governance Mechanisms and Company Performance: Evidence from Malaysian Companies.” International Review of Business Research Papers, 7(6), pp.101-114.

Antle, R. (1989). Commentary on International Boundaries in Accounting Research, Accounting Horizons, June.

Aras, G., \& Crowther, D. (2008). "Governance and Sustainability: An Investigation into the relationship Between Corporate Governance and Corporate Sustainability.” Management Decision, 46(3), pp.433-448.

Asein, A.A. (2014). Sarbanes - Oxley Act: Evolving a Corporate Conscience. The Nigerian Accountant, The Official Journal of the Institute of Chartered Accountants of Nigeria, January/March; Vol. 47, No.1; pp.18-25.

Ashbaugh-Skaife, H. \& Lafond, R. (2006). Corporate Governance and the Cost of Equity Capital: An Analysis of U.S. and Non-U.S. Firm's GMI Ratings. Retrieved from: http://www.gmiratings.com/performance.aspx.

Awoyemi, (2009). Corporate Governance, Finance Crisis and the Nigerian Leadership Meltdown. ISSN 15798842. Vol.1 No.22.

Azim, M.I. (2012). "Corporate Governance Mechanism and their Impact on Company Performance: A Structural equation Model Analysis.”Australian Journal of Management, 37(3), pp. 481-505.

Babalola, Y.Y. (2013). The Effect of Firm Size on Firm's Profitability in Nigeria. Journal of Economics And Sustainable Development, 14(5), pp. 90-95.

Babatunde, M.A. and Olaniran, O. (2009). "The Effects of Internal and External Mechanism on Governance and Performance of Corporate Firms in Nigeria.” Journal of Corporate Ownership and Control, 7(2), pp.330344.

Bainbridge, S.M. (1993). "Independent Directors and the ALI Corporate Governance Project." George Washington Law, 61, pp.1034-1083.

Bajpai, N. (2011). Business Research Methods. New Delhi: Dorling Kingsley.

Baker, R. (2009). "Observation on the Current Crisis from a Corporate Governance Perspectives." Institute Of Directors Report, February 20.

Baltagi, B. (1995). Econometrics Analysis of Panel Data, Wiley, Chichester.

Balasubramanian, B.N., Black, B.S, \& Khanna, V.S. (2008). Firm Level Corporate Governance in Emerging Markets: a Case Study of Indian. ECGI - Law Working Paper, 199(2009) pp. 8-11; Retrieved from: http://www.ssrn.com

Barbosa, N. and Louri, H. (2005). Corporate Performance: Does Ownership Matter? A Comparison of Foreignand Domestic- owned Firms in Greece and Portugal. Review of Industrial Organization, 27(1), pp. 73102

Barrick, M.R. and Mount, M.K. (1991). "The Big Five Personality Dimensions and Job Performance: A MetaAnalysis.” Personal Psychology, 44(1).

Bathula, H. (2008). Board Characteristics and Firm Performance: Evidence from New Zealand. PhD Dissertation, AUT University. Available at: http://www.aut.researchgateway.ac.

Baysinger, B. and Hoskisson, R.E. (1990). "The Composition of Boards of Directors and Strategic Control: Effects on Corporate Strategy.” Academy of Management Review, vol.15, pp. 72-87.

Baysinger, B.D and Bulter, H.N. (1985). Corporate Governance and the Board of Directors: Performance Effects of Change in the Board Composition. Journal of Law, Economics and Organization, Vol.1, pp. 101-124.

Beatty, R.E. and Zajai, E.J. (1994). “Top Management Incentives, Monitoring, and Risk-Bearing: A Study Of Executive Compensation, Ownership, and Board Structure in Initial Public Offerings.” Administrative Science Quarterly vol.39, pp. 313-335.

Beaver, W.H. (1966). Financial Ratios as a Predictor of Failure, Journal of Accounting Research, Vol.4, 71-111.

Berger, P.G., Ofek, E. and Yermack, D.L. (1997). Managerial Entrenchment and Capital Structure Decisions. Journal of Finance, 52(4), 1411-1438.

Berthelot, M.J. (2011). A Glossary of Corporate Governance terms. The Corporate Directors Forum. Available at: http://www.directorsforum.com

Berndt, T. and Leibfried, P. (2007). "Corporate Ownership and Control: Corporate Governance and Financial Reporting." Vol.4, Issue4, pp.397 - 400.

Bhagat, S. and Black, B. (2000). "The non-correlation between Board Independence and Long-term Firm Performance.” Journal of Corporation Law, 27(2), Pp.231-273.

Bhagat, S. and Bolton, B. (2009). "Sarbaness - Oxley, Governance and Performance." Retrieved from SSRN: http://www.ssrn.com 
Blake, A. (1999). Dynamic Directors: Aligning Board Structure for Business Success. Basingstroke: Macmillian.

Black, B., Jang, H. and Kim, W. (2003). Does Corporate Affect Firm Value? Working Paper 327, Stanford Law School.

Black, J. and Bhaget, K.M. (2003). Does Corporate Governance Affect Frim Value? Evidence from Korea, Stanford Law School, Economics Working Paper.

Blair, M.M. (1995). Ownership and Control. Washington, D.C.: The Brookings Institution.

Blankson, A. (2011). Critique of the Nigerian Code of Corporate Governance. Newsletter, March. Available at: www.ainablankson.com

Boatright, J. (2001). "Ethics and Corporate Governance: Justifying the Role of a Shareholder", in the Blackwell Guide to Business Ethics, Bowre ed.

Booth, J.R. \& Deli, D.N. (1996). "Factors Affecting the Number of Outside Directors Held by CEOs." Journal of Financial Economics, 40, pp. 81- 104.

Borokhovich, K.A., Brunarski, K., Harman, Y., \& Kehr, J.B. (2005). “Dividends, Corporate Monitors, and Agency Costs." The Financial Review, 40, pp. $37-65$.

Bosch, H. (1995). The Director at Risk: Accountability in the Boardroom. Melbourne Pearson Professional.

Bouraoui, T. and Louri, T. (2014). The Impact of Adjustment in Capital Structure in Mergers and Acquisitions on US Acquirers' Business Performance. The Journal of Applied Business Research, January/February, 30(1) Pp. $27-41$.

Bourne, M. and Franco, M. (2003). Corporate Management. Cranfield Centre for Business Performance, Cranfield, UK.

Boyd, B.K. (1994). "Board Control and CEO Compensation.” Strategic Management Journal, 15, pp.335 - 344.

Bratton Jr., W.W. (1989). The New Economic Theory of the Firm: Critical Perspective from History. Stanford Law Review, 41(6), pp. 1471-1527.

Brennan, N. (2006). Boards of Directors and Firm Performance: Is there an expectation Gap? Corporate Governance: An International Review, 14; 6, pp.577 - 593.

Broome, L.L., Conley, J.M. and Krawiee, K.D. (2011). Dangerous Categories: Narratives of Corporate Board Diversity. North Carolina Law Review, (89), 759.

Brown, L. and Caylor, M. (2004). Corporate Governance Study: The Correlation between Corporate Governance and Company Performance. Institutional Shareholder services (ISS). Retrieved from: http://www.stybelpeabody.com

Brown, L. and Caylor, M. (2005). Corporate Governance and Firm Performance Working Paper, Georgia State University.

Brown, W.A. (2005). Board Development Practices and Competent Board Members: Implication for Performance. An Article for Presentation at Midwest Centre for Non-profit Leadership, Non-profit Governance Conference, March 31 - April 1, 2005. Available at: http://www.nonprofit.asu.edu.

Brundtland Report (1987). Report for the World Commission on Environment and Development.

Burns, R.B. \& Burns, R.A. (2008). Business Research Methods and Statistics Using SPSS. London: SAGE Publications.

Business Roundtable (2012). 2012 Principles of Corporate Governance. March 27. Available on: http://www.businessroundtable.org

Cadbury, A. (1992). The Financial Aspect of Corporate Governance - A Report of the Committee on Corporate Governance. London: Gee and Co. (2002). Corporate Governance and Chairmanship: A Personal View. New York: Oxford University Press.

Carpenter, M.A., Pollock, T.G. \& Leary, M.M. (2003). Testing a Model of Reasoned Risk-Taking: Governance, the Experience or principals and Agents and Global Strategy in High- Technology IPO Firms. Strategic Management Journal, vol.23, pp. 367-375.

Carpenter, M.A. and Sanders, W.G. (2002). Top Management Team Compensation: The Missing Link Between CEO Pay and Firm Performance. Strategic Management Journal, vol.23, pp. 367-375.

Carter, C.B. and Lorsch, J.W. (2004). Back to the Drawing Board: Designing Corporate Boards a Complex World. Boston: Harvard Business School Press.

Carter, D. A., Simkins, B. J. and Simpson, W.G. (2003). "Corporate Governance, board diversity And Firm Value”. The Financial Review, 38, pp. 44-53.

Carver, J. (1997). Board Self-Assessment (Carver Guide 8). San Francisco: Jossey-Bass Publishers.

Carver, J. and Oliver, C. (2002). Corporate Boards that Create Value: Governing Company Performance from the Board Room. San Francisco: John Wiley.

Catalyst (2007). The Bottom Line: Corporate Performance and Women's Representation on Boards.

Central Bank of Nigeria (2014). Code of Corporate Governance for Banks in Nigeria Post Consolidation. Available at: http://www.ecgi.org/codes/documents 
Charreaux, G. (2004). Corporate Governance Theories: from Micro - Theories to National Systems Theories. Working Paper of FARGO, December. Available at: http://www.leg.u-bourgogne.fr

Chartered Financial Analyst CFA Institute (2013). Corporate Finance.

Chen, Z., Cheung, Y.L., Stouraitis, A. and Wong, A.W.S. (2005). "Ownership Concentration, Firm Performance, and Dividend Policy in Hong Kong” Pacific- Basin Finance Journal, 13, 4, pp.431 - 449.

Chhiber, P.K. and Majumdar, S.K. (1999). Foreign Ownership and profitability: Property Rights, Control and Performance of Firms in Indian Industry. Journal of Law and Economics, 46(3), pp. 209-238.

Chiang, H. (2005). An Empirical Study of corporate Governance and Corporate Performance. Journal of American Academy of Business, Cambridge; March, 6, 1; pp. 95-101. Available at: http://www.iobf.org

Chidambaram, N.K., Palia, D., \& Zheng, Y. (2006). Does Better Corporate Governance "Cause" better Firm Performance? Unpublished Working Paper.

Chief Olabode George VS Federal Republic of Nigeria in the Supreme Court of Nigeria Holden at Abuja on Friday, the $13^{\text {th }}$ Day of December, 2013; Suit No: SC. 180/2012

Chiejine, F.C. (2010). Corporate Governance in the Nigerian Banking Sector: An Ethical Analysis of the 2009 Regulator Intervention and Operators' Behaviours. A Thesis Submitted for Masters of Science in Organizational Dynamics, University of Pennsylvania, Philadelphia. Retrieved from: http://www.repository.upenn.edu/od thesis

Chin, J., Widing II, R., \& Paladino, A. (2004). Influence of Resource Dependency Theory on Firm Performance, Managing the Competitive Environment. Available on: http://www.smib.vuw.ac,nz

CIPM (2013). Study Pack on Comparative Management and Administration, Intermediate Level II, Second Edition.

Claessens, S. and Joseph, P.H.F. (2003). Corporate Governance in Asia: A Survey, Working Paper, Finance Group. University of Amsterdam Roetersstraat Amsterdam.

Clancanelli, P. and Gonzalez, I.A.R. (2000). Corporate Governance in Banking: A Conceptual Framework. Social Science Research Network. Available at: http://www.ssrn.com

Clarke, T. (2010). Recurring Crisis in Anglo-American Corporate Governance, 29 Contributions to Political Economy, 9

Clifford, P., and Evans, R. (1997). Non - Executive Directors: A Question of Independence. Corporate Governance, 5,4, pp. $224-231$.

Coffey, B.S. \& Wang, J. (1998). "Board Diversity and Managerial Control as Predictors of Corporate Social Performance." Journal of Business Ethics, 17, pp. 1595-1603.

Cohen, J., Krishnamoorthy, G. and Wright, A. (2002). "Corporate Governance and the Audit Process." Contemporary Accounting Research (Winter); pp.573-594.

(2004). "The Corporate Governance Mosaic and Financial Reporting Quality." Journal of Accounting Literature, pp.87-152.

Coles, J.W., McWilliams, V.B., and Sen, N. (2001). "An Examination of the Relationship of Governance Mechanisms to Performance." Journal of Management, 27, 1, pp.23 -50.

Collier, J.C. and Roberts, J. (2001). "An Ethics for Corporate Governance.” African Journal of Business Ethics, $1(1)$, pp.1-7.

Companies and Allied Matters Act as Amended, (2004). Federal Republic of Nigeria Official Gazette

Conger, J.A. and Lawlor III, E. (2002). "Evaluating the Directors: The Next Step In Boardroom Effectiveness." Ivey business Journal, September/October.

Connelly, J.T., and Limpaphayom, P. (2004). "Environmental Reporting and Firm Performance: Evidence from Thailand.” The Journal of Corporate Citizenship, 13, 1, pp.37 - 149.

Conyon, M. and Peck, S. (1998). Board Size and Corporate Performance: Evidence From European Countries. European Journal of Finance, 41, pp.291 - 304.

Core, J.E., Guay, W.R. and Rusticus, T.O. (2006). "Does Weak Governance Cause Stock Returns? An Examination of Firm Operating Performance and Investors' Expectations." The Journal of Finance, 61(2), pp.655-687.

Coulson-Thomas, C. (2007). "How 'winning' Boards Contribute to Corporate Growth.” Strategy Series, 8(5), pp.369-376.

Curley, K.G. (2005). "Examining the Non - Executive Director's Role from a non - Agency Theory Perspective: Implications Arising from the Higgs Report." British Journal of Management, 16; pp.1 - 4.

Cutting, B. and Kouzmin, A. (2002). "Evaluating Corporate Board Cultures and Decision Making" Corporate Governance, 2(2), pp.27- 45 .

Dabor, A.O., et al. (2015). Impact of Corporate Governance on Firms' Performance. International Journal of Economics, Commerce and Management, United Kingdom, Vol. III, Issue 6, June; pp.634-653. Available at: http://ijecm.co.uk

Daily, C., Dalton, D., and Rajagopalan,N. (2003). Governance Through Ownership: Centuries of Practice, Decades of Research. Academy of Management Journal, vol.46: pp. 115-158. 
Daily, C.M, Dalton, D.R., and Cannella, A.A (2003). Corporate Governance: Decades of Dialogue and Data. Academy of Management Review, 28(3); pp. 371-382.

Daily, M.D., Dalton, D.R., Cannela, A.A. (2003). "Corporate Governance: Decades of Dialogue and Data." Academy of Management Review, 28 (3), pp.371-382.

Dalton, D.R. (1993). Board of Directors Leadership and Structures: Control and Performance Implications Entrepreneurship: Theory and Practice. Vol.

Dalton, D.R. Daily, C.M., Ellstrand, A.E. and Johnson, J.L. (1998). Meta - Analytic Reviews of Board Composition, Leadership Structure and Financial Performance. Strategy Management Journal, vol.19 (3), pp. 269-290.

Dalton, D., Daily, C., Ellstrand, A. and Johnson, J.L. (1999). "Number of Directors and Financial Performance: A Metal Analysis.” Academy of Management Journal, 42(6), pp.674 - 686.

Davies, A. (1999). "A Strategic Approach to Corporate Governance.” Aldershot: Gower, vol.59, pp. 34-37.

Davis, G.F. and Cobb, J.A. (2009). Resource Dependence Theory: Past and Future: Available at: http://www.webuser.bus.umich.edu

Davis, J.H., Schoorman, F.D. and Donaldson, L. (1997). Towards a Stewardship Theory of Management. Academy of Management Review, vol.22, No.1, pp. 20-47. Available on: http://www.jstor.org

Decenzo, D.A. \& Robbins, S.P. (2005). Fundamentals of Human Resource Management, $8^{\text {th }}$ Edition. New York: John Wiley and Sons.

Dehaene, A., De Vuyst, V., and Ooghe, H. (2001). "Corporate Performance and Board Structure in Belgian Companies.” Large Planning, 34, 3, pp.383 - 398.

Demb, A. and Neubauer, F.F. (1992). The Corporate Board: confronting the Paradoxes. Long Range Planning, vol.25, No.3, pp. 9-20.

Denning, S. (2004). The Unanticipated Risks of Maximizing Shareholder Value. Forbes, October 14. Available at: www.forbes.com.

Dilenschneider, R.L. (1996). The Board as a Think tank. Directors \& Boards, Vol.21, No. 1, pp. 30-38.

Dixon, J. and Dogan, R. (2003). "Corporate Decision Making: Contending Perspectives And Their Governance Implications": Corporate Governance, 3(1); pp.39 -57.

Dobbin, F. and Jung, J. (2011). Corporate Board Gender Diversity and Stock Performance: The Competence Gap or Institutional Investor Bias.North Carolina Law Review, (89), 809.

Dobrzynski, R.L. (1991). Chairman and CEO: One Hat too Many. Business Week, Vol.12(3), pp.263-280, November 18.

Donaldson, L. and Davis, J. (1991). "Stewardship Theory or Agency Theory: CEO Governance and Shareholders Returns" Australian Journal of Management, 16(1), pp.49- 65.

Donaldson, T. and Preston, L.E. (1995). The Stakeholder Theory of Corporation: Concepts, Evidence, and Implications. Academy of Management Review, vol.15, No.3, pp. 369-381.

Drobetz, W., Schillhofer, A. and Zimmermann, H. (2003). Corporate Governance and Expected Stock Returns: The Base of Germany, Working Paper, University of Basel.

Drobetz, W. (2004). The Impact of Corporate Governance on Firm Performance, Working Paper, Department of Corporate Finance, University of Basel.

Drucker, P.F. (1986). The Practice of Management.

Eisenhardt, K. (1989). “Agency Theory: An Assessment and Review.” Academy of Management Review, 14, pp. 57-74.

Eisenhardt, K.M. and Bourgeois, L.J. (1988). Politics of Strategic Decision Making in High Velocity Environments: Towards a Midrange Theory. Academy of Management Journal, Vol.31, pp. 737-770.

Eisenberg, T., Sundgren, S. and Wells, M. (1998). "Larger Board Size and Decreasing Firm Value in Small Firms." Journal of Financial Economics, Vol.48, No.1; Pp.35-54.

Eisenhofer, J.W. (2010). Does Corporate Governance Matter to Investment Returns? Grant and Eisenhofer P.A. available on: http://www.gelaw.com

Ekineh, D. (2009). "Reform Agenda for Corporate Governance in Nigeria: Disclosure and Reporting Requirement." Being a paper presented at Round Table on Demystifying Corporate Governance Organised by the Institute of Director (IOD), Centre for Corporate Governance, Ikoyi-Lagos, Tuesday, October 27.

Enofe, A. and Isiavwe, D. (2012). "Corporate Disclosure and Governance in the Nigerian Banking Sector: An Empirical Evaluation.” the International Research Journal of Social Science and Management, Singapore. Available at: http://www.tij.sg.

Erhardt, N.L., Werbel, J.D. and Shrader, C.B. (2003). Board of Director Diversity and Firm Financial Performance. New York: Blackwell Publishing Ltd.

Eye, V.A. and Schuster, C. (1996). Regression Analysis for Social Sciences. London: Academic Press.

Ezzamel, M. and Watson, R. (2002). "Pay Comparability Across and Within UK Boards: An Empirical Analysis of the Pay Cash Awards to CEOs and the Board Members." Journal of Financial Economics, 38(2), 
pp. $207-232$.

Fama, E. and Jensen, M. (1983). Separation of Ownership and Control. Journal Of Law and Economics, 26, pp. 301-326.

Fama, E.F. (1980). “Agency Problems and the Theory of the Firm.” Journal of Political Economy, vol.88, pp. 288307.

Fama, E.F. \& Jensen, M.C. (1983). "Separation of Ownership and Control.” Journal of Law and Economics, 26, pp. 301-325.

Fapohunda, M.A. (1988). Generic Skills and Job-Specific Skills in CIPM (2013), Study Pack on Comparative Management and Administration Intermediate Level II, Second Edition.

Fasina, H.T., Olowookere, J.K. Oyedele, K.S. (2012). Effect of Assets Profile on Earnings and Shareholders Fund Performance of Leading Manufacturing Company in Nigeria. Research Journal of Finance and Accounting, Vol.3, No.10; pp.49-56. From: http://www.wikipedia.org

Ferreira, D. (2010). "Board Diversity" in H. Kent Baker and Ronald Anderson, eds., Corporate Governance: A Synthesis of Theory, Research, and Practice. Hobioken, N.J.: Wiley, pp. 225-243. (2010). Board Diversity. London School of Economics. Available at: http://personal.ise.ac.uk

Filiz, A. (2013). The Company Secretary within the Corporate Governance Framework. Dissertation of the University of St. Gallen, School of Management, Economics, Law, Social Sciences and International Affairs for the Award of The Title of Doctor Oeconomiae, May 21. From: Verdi.unisg.ch

Financial and Legal Skills Partnership (20xx). Board Effectiveness: Statements of Good Practice. Available at: http://www.financialskillspartnership.org.uk

Financial Reporting Council, FRC (2014). The UK Corporate Governance Code. Available at: http://www.frc.org.uk

Financial Reporting Council of Nigeria (2015). Exposure Draft of National Code Of Corporate Governance 2015: Private Sector Code. Available on: http://www.financialreportingcouncil.gov.ng. Retrieved: July 3, 2015.

Finkelstein, S. and D'Aveni, R.A. (1994). CEO Duality as a Double-Edged Sword: How Boards of Directors Balance Entrenchment Avoidance and Unity Of Command. Academy of Management Journal, vol.37, pp. $1079-1108$

Fisher, I. (1969). Income and Capital, in Parker, R.H. and Harcourt, G.C. (eds) Readings in the Concept and Measurement of Income, Cambridge University Press.

Fligstein, N. (1993). The Transformation of Corporate Control. Cambridge: Harvard University Press.

(2001). The Architecture of Market - An Economic Sociology of Twenty-First-Century Capitalist Society. Princeton: Princeton University Press.

Forbes, D.P. \& Milliken, F.J. (1999). "Cognition and Corporate Governance: Understanding Boards of Directors as Strategic Decision-Making Groups.” Academy of Management Review, 24, pp.489-505.

Fosberg, R. (1989). Outside Directors and Managerial Monitoring. Akron Business and Economic Review, vol.20, pp. $24-32$.

Fredrick, R. (2000). "Disclosure: A Corporate Governance Tool that Really Works." A Presentation on 'The Role of Disclosure in Strengthening Corporate Governance and Accountability' at the Third Meeting of the Russian Corporate Governance Roundtable, Moscow, 15-16 November. Retrieved from: http://www.oecd.org/ Corporate Governance affairs on December 252012

Freeman, R.E. (1984). Strategic Management: A Stakeholder Approach. Boston: Pitman.

Friedman, M. (1953). Essays in Positive Economics. Chicago: University of Chicago Press.

Ganiyu, Y.O. and Abiodun, B.Y. (2012). The Impact of Corporate Governance on Capital Structure Decision of Nigerian Firms Research Journal in Organizational Psychology and Educational Studies 1(2) 121-128. In Emerging Academy Resources. Retrieved from: http://www.emergingresource.org on March 12, 2015.

Garrett, B. (1996). The Fish Rots from the Head- The Crisis in Our Boardrooms: Developing the Crucial Skills of the Competent Director. London: Harper Collins.

Ghosh, C., Nag, R., and Sirnmans, C.F. (2000). The Pricing of Seasoned Equity Offerings: Evidence from REITs. Real Estate Economics, 28 (3), pp.363-384.

Ghoshal, S. (2005). Bad Management Theories are Destroying Good Management Practices. Academy of Management Learning and Education, 4(1); pp. 75-91.

Gibbs, P.A. (1993). "Determinants of Corporate Restructuring: The Relative Importance of Corporate Governance, Takeover Threat and Free Cash Flow." Strategic Management Journal, 14, pp.51 - 69.

Gill, A., Biger, N. and Mathur, N. (2011). The Effects of Capital Structure on Profitability: Evidence from The United States. International Journal of Management, December, 28(4).

Gkliatis, I. (2009). Board of Directors and Firm Performance: A Combination of Agency and Dependence Theory Perspectives. BBS Doctoral Symposium, $23^{\text {rd }}$ and $24^{\text {th }}$ March. Available at: http://www.brunel.ac.uk

Glautier, M., Underdown, B. and Morris, D. (2011). Accounting Theory and Practice (eighth Edition). England: 
Pearson Education Ltd.

Global Reporting Initiative (2013). 64 Sustainability Reporting Guidelines: Reporting Principles and Standard Disclosures. Global Reporting Initiative. Available at: http://www.globalreporting.org

Goddard, J., Tavakoli, M. and Wilson, J. (2005). Determinants of Profitability in European Manufacturing and Services: Evidence from a Dynamic Panel Model. Applied Financial Economics, 15(18), pp. 1269-1282.

Goergen, M. and Renneboog, L. (2000). Insider Control by Large Investor Groups and managerial Disciplining in Listed Belgian Companies. Managerial Finance, Vol.26, pp. 22-41.

Golden, B.R. \& Zajac, E.J. (2001). When Will Board Influence Strategy? Inclination X Power = Strategic Change. Strategic management Journal, Vol.15, No.3, pp. 241-250.

Gomez, P. and Korine, H. (2011). Entrepreneurs and Democracy: A Political Theory of Corporate Governance. London: Cambridge University Press.

Gompers, P., Ishii, J. \& Metrick, A. (2003). “Corporate Governance and Equity Prices.” The Quarterly Journal of Economics, 118(1), pp. 107-156.

Goodpaster, K.E. (2004). "Ethics or Excellent? Conscience as Check on the Unbalanced Pursuit of Organizational Goals.” Ivey Business Journal, 2(3), Pp.1 - 3.

Goodstein, J., Gautun, K., and Boeker, W. (1994). "The Effect of Board Size and Diversity on Strategic Change." Strategic Management Journal, 15, 3, pp.241 - 250.

Gourevitch, P. A. (2003). The Politics of Corporate Governance Regulation. At Yale Law Journal, Vol. 112, pp. 1829 - 1880. Available at: http//www.yalelawjournal.org

Governance Metrics International, \& Byun, S.J (2006). Governance and Performance. Recent Evidence. Governance Metrics International. From: http://www.gmiratings.com/performance.aspx.

Gyakari, N.C. (2009). Internal Corporate Governance Structures and Firm Financial Performance: Evidence from South African Listed Firms. Doctoral Thesis, University of Glasgow.

Hambrick, D.C and Mason, P.A. (1984). Upper Echelons: the Organizations as a Reflection of its Top Managers. Academy of management Review, Vol.16, pp. 193-206.

Handy, C. (2002). What's a Business For? Harvard Business Review, December.

Haniffa, R. and Hudaib, M. (2006). "Corporate Governance Structure and Performance of Malaysian Listed Companies.” Journal of Business Finance and Accounting, 33, 7/8, pp.1034 - 1062.

Hansman, H. and Kraakman, R. (2001). The End of History for Corporate Law. Georgetown Law Journal, 89; pp.439.

Hawley, J. P., and Williams, A. T. (1996). Corporate Governance in the United States: The Rise Of Fiduciary Capitalism. Working Paper, Saint Mary's College of California, School of Economics and Business Administration.

Hax, A.C. and Majluf, N.S. (1979). Strategic Management. New Jersey: Prentice-Hall, Inc.

Hermalin, B. and Weisbach, M. (1998). "Endogenously Chosen Boards of Directors And Their Monitoring the CEO." American Economic Review, 88(4), pp.96 -118.

(2002). "Boards of Directors as Endogenously Determined Institutions: A Survey of the Economy Literature." Economy Policy Review.

Higgs, D. (2003). Review of the Role and Effectiveness of Non-executive Directors. A Higgs Committee Report, January. Available at: www.dti.gov.uk/c/d/non exec review.

Hill, C.W.L., and Snell, S.A. (1998). "External Control, Corporate - Strategy and Firm Performance in Research - Intensive Industries.” Strategic Management Journal, 9, Pp. 577 - 590.

Hillman, A.J., (2005).Politicians on the Board: Do Connection Affect the Bottom Line? Journal of Management, vol.31, pp. 464- 481.

Hillman, A.J., Cannellas, A.A., \& Harris, I.C. (2002). "The Resource Dependence Role of Corporate Directors: Strategic Adaptation of Board Composition in Response to Environmental Change." Journal of Management Studies, 37, pp. 235-255.

Hillman, A.J., Dalziel, T. (2003). "Boards of Directors and Firm Performance: Integrating Agency and Resource Dependence Perspectives." Academy of Management Review, 28 (3), pp. 383-396.

Hillman, A.J., Schropshire, C. \& Cannella, A.A. (2007). "Organizational Predictors of Women on Corporate Boards.” Academy of Management Journal, 50, pp. 941-952.

Hooghiemstra, R. and Manen, J. (2004). "Non - Executive Directors in the Netherlands: Another Expectations Gap?" Accounting and Business Research, 34, pp.25 - 42.

Htay, S.N.N. (2012). "The Impact of Governance on the Voluntary Accounting Information Disclosure in Malaysian Listed Banks." Global Review of Accounting and Finance, 3(2); pp.128 - 142.

Htay, S.N.N., Syed, A.S. and Meera, A.K.M. (2013). "Let's Move to Universal Corporate Governance Theory." Middle - East Journal of Scientific Research 15(7), pp.1047 - 1053. Available at www.idosi.org

IA Research (2002). "A Report on Corporate Governance at Five Companies that Collapsed in 2001." Retrieved from: http://www.cc/sr.law.unimelb.edu.au 
Ibrahim, Q., Rehman, R. and Raoof, A. (2010). Role of Corporate Governance in Firm Performance: A Comparative Study between Chemical and Pharmaceutical Sector in Pakistan.

Ijas, J. (2012). The Impact of Board Gender Diversity on Corporate Responsibility Performance in the FTSE 100. Dissertation Submitted in Partial Fulfilment of the requirement for the MSc in Corporate Governance and Business Ethics, Department of Management, Brubeck College, University of London, October 1.

Institute of Chartered Accountants of Nigeria, ICAN (2009a). Financial Reporting and Ethics. Lagos: VI Publishing Limited.

(2009b). Strategic Financial management: Professional Examination II Study Pack. Lagos: VI Publishers.

Ireland, P. (1999). Company Law and the Myth of Shareholder Ownership. Modern Law Review, 62(1); pp. 3257.

Janis, I.L. (1972). Victims of Group think: A Psychological Study of Foreign - Policy Decisions and Fiascoes. Boston: Houghton Mifflin.

Jean-Paul Page (2005). Corporate Governance and Value Creation. Retrieved From: www.cfapubs.org

Jeffrey, A.A., Fennell, M.L., and Halpern, M.T. (1993). "Leadership Instability in Hospitals: The Influence of Board- CEO Relations and Organization Growth and Decline." Administrative Science Quarterly, vol.38.

Jensen, M.C. (1986). “Agency Cost of Free Cash Flow, Corporate Finance and Takeovers.” American Economic Review, vol.76, pp.323-329.

Jensen, M.C. (1993). The Modern Industrial Revolution, Exit and the Failure of Internal Control Systems - The Journal of Finance. Vol.48, No.38, pp. 831-880. (2001). "Value Maximization, Stakeholder Theory and the Corporate Objective Function." Journal of Applied Corporate Finance, Fall, 2004.

Jensen, M.C. and Meckling, W.H. (1976) Theory of the Firm: Managerial Behaviour, Agency Costs and Ownership Structure. Journal of Financial Economics, 3(4), pp. 305-360.

Jensen, M.C. and Ruback, R.S (1983). The Market for Corporate Control: The Scientific Evidence. Journal of Financial Economics, 11(1-4), pp. 5-50

Jensen, M.C. and Warmer, J.B. (1988). The Distribution of Power among Corporate Managers, Shareholders, and Directors. Journal of Financial Economics, 20(1/2), pp. 3-24.

Johannisson, B. and Huse, M. (2000). "Recruiting Outside Board Members in the Small Family Business. Ideological Challenge.” Entrepreneurship and Regional Development, 12(4), pp.353 - 378.

John, K. and Senbert, L.W. (1998). "Theory of the Firm Managerial Behaviour, Agency Costs and Ownership Structure." Journal of Banking and Finance, 22, pp.371- 403.

Johnson, J., Daily, C., \& Ellstrand, A. (1996). "Board of Directors: A Review and Research Agenda." Journal of Management, 22, pp. 409-438.

Julizaerma, M.K. and Sori, Z.M. (2012). "Gender Diversity in the Boardroom and Firm Performance of Malaysian Public Listed Companies.” Procedia-Social and Behavioural Sciences, ELSEVIER, Vol.65, December 3, 2012, pp.1077-1085.

Kajola, (2008). Corporate Governance and Frim Performance, the Case of Nigeria Listed Firms. European Journal of Economics, Finance and Administrative Science. ISSN 1450-2887.

Kakabadse, et al. (2001). "Board Governance and Company Performance: Any Correlations?" Corporate Governance 1(1); pp.24-30.

Kang, J. and Shivdasani, A. (1995). "Firm Performance, Corporate Governance and Top Executive Turnover in Japan.” Journal of Financial Economics, 38(1), Pp.29 - 58.

Kashif, R. (2008). A Comparison of Corporate Governance and Firm Performance in Developing (Malaysia) and Developed (Australia) Financial Market. Melbourne: Centre for Strategic Economic Studies.

Katz and Kahn (1978). Managerial Skills in CIPM (2013), Study Pack on Comparative Management and Administration Intermediate Level II, Second Edition.

Keasey, et al. (1997). Corporate Governance: Economic, Management and Financial Issues. Oxford: Oxford University Press.

Kenser, I.F. (1987). Directors' Stock Ownership and Organizational Performance: “An Investigation of Fortune 500 Companies." Journal of Management, 13, pp.499 - 508.

Kiel, G.C., and Nicholson, G.J. (2003). Boards that Work: A New Guide for Directors. Australia: McGraw - Hill.

King 1, M. (1994). King Committee Report of Corporate Governance Code in South Africa.

Kirkpatrick, G. (2009). "The Corporate Governance Lessons from the Financial Crisis." OCED Financial Market Trends.

Klapper, L.F. and Love, I. (2003). Corporate Governance, Investors Protection, and Performance in Emerging Markets, Journal of Corporate Finance, 195; pp.1 - 26.

Klai, N. and Omri, A. (2011). "Corporate Governance and Financial Reporting Quality: the Case of Tunisian Firms.” International Business Research, Vol.4, No.1, January. Retrieved from: 
http://www.ccsenet.org/ibr

Kocurek, P., Burger, C. and Birchard (2003). “Corporate Governance: Hard Facts about Soft Behaviours.” Strategy + Business, 5(30): 30 .

Kolb, et al., (1974). Learning Style Inventory, in CIPM (2013) Study Pack on Training And Development. Intermediate Level II, Second Edition.

Korn/Ferry International and Egan Associates (2002). Boards of Directors Study in Australia and New Zealand 2002.

(2003). Boards of Directors Study in Australia and New Zealand 2003.

(2005). Boards of Directors Study in Australia and New Zealand 2005.

Kosnik, R.D. (1990). Effects of Board Demography and Directors Incentives on Corporate Greenmail Decisions. Academy of Management Journal, Vol.33, Pp. 129 - 151.

Kothari, C.R. (2004). Research Methodology: Methods and Techniques (Second Revised Edition). New Delhi: New Age International Publishers.

Krieger, M.P. (1991). "The Importance of Role of Subsidiary Board in MNCs: Comparative Parent and Subsidiary Perceptions.” Management International Review, 36(3), Pp.317 - 331.

Kruger, H.B. (2012). The Impact of Board Diversity on Corporate Governance in Medium - Sized Private Enterprises in Gauteng. A Dissertation Submitted for the Degree of Magister Technological in the Subject of Business Administration at the University of South Africa, November.

Kumar, J. (2004). Agency Theory and Firm Value in India.

La Porta, R., et al; (2000). "Investor Protection and Corporate Governance." Journal of Financial Economics, 58, pp.3 -27.

La Porta, R., et al; (2002). "Investor Protection and Corporate Valuation.” Journal of Finance, Vol.57; pp.1147 1170. Available from: http://www.dx.doi.org

Lamberg, L. (2009). Impact of Liquidity Management on Profitability: A Study of The Adaptation of Liquidity Strategies in a Financial Crisis.

Langevoort, D. (2011). Puzzles about Corporate Boards and Board Diversity. North Carolina Review, (89), 841.

Lashgari, M. (2004). Corporate Governance: Theory and Practice. The Journal of American Academy of Business, Cambridge, September. Available at: http://www.tharcision.com.br.

Lazonick, W. and O'Sullivan, M. (2000). Maximizing Shareholder Value: New Ideology for Corporate Governance. Economy and Society, 29(1), pp.13-35.

Lee, J. (2009). Does Size Matter in Firm Performance? Evidence from US Public Firms. International Journal of the Economics of Business, 16(2), pp.189-203.

Lee, S.A., and Phan, P.H. (2000). "Competencies of Directors in Global Firms: Requirements for Recruitment and Evaluation." Corporate Governance, 8, Pp.204-214.

Levitt, A. (1999). "Levitt Play up Shareholder Rights to Directors” Investors Relations Business. April 12:2

(2000). "Renewing the Covenant with Investors." Speech at New York University Centre for Law and Business. Retrieved from: http://www.sec.gov/news/speeches.

Lewis, P., Saunders, M. and Thornhill, A. (2009). Research Methods for Business Students. Harlow: Pearson Education.

Liargovas, P.G. (2008). Factors Affecting Firms Competitiveness: The Case of Greek Industry.

Liargovas, P.G. and Skandalis, K.S. (2010). Factors Affecting Firms' Performance: The Case of Greece.

Liewellyn, D. and Rajeeva, S. (2000). Monitoring and Control of Banks: The Role of Regulation and Corporate Governance, in the book of Corporate Governance In Banking and Finance, Edited by Reddy, Y.R.K and Yerman, R.T., New Delhi: McGraw - Hill Publishing Co. Ltd.

Lipman, F.D. and Lipman, L.K. (2006). Corporate Governance Best Practices: Strategies for Public, Private, and Not-for-Profit Organizations. New Jersey: John Wiley and Sons, Inc.

Lipton, M. and Lorch, J.W. (1992). “A Modest Proposal for Improved Corporate Governance.” The Business Lawyer, 48, 1, pp.59- 77.

Long, C.S., Mahanra, G.R. and Ajagbe, M.A. (2013). “Can Employee Share Option Scheme Improve Firm's Performance? A Malaysian Case Study.” Information Management And Business Review, 5(3), pp.119128.

Lorsch, J.W. (1995). Empowering the Board. Harvard Business Review, 73, pp.107 - 117.

Luckerath - Rovers, M. (2011).Women on Boards and Firm Performance. Available at: http://www.springer.com Lundy, J. (1991). Follow, or Get Out of the Way. New York: Berkley.

Lybaert, N. (1998). "The Information Used in an SME: Its Importance and Some Elements of Influence." Small Business Economics, 10, pp.171-191.

Mace, M. (1971). Directors: Myth and Reality. Boston: Harvard Business School Press.

Maheshwari, D. (2013). Models of Corporate Governance Education, Economy and Finance. Business, December 07 Available at: www.slideshare.net 
Mak, Y.T. and Yuanto, K. (2003). "Board Size Really Matters: Further Evidence on the Negative Relationship between Board Size and Firm Value." Pulses by Singapore Stock Exchange.

Mallin, C. (2010). Corporate Governance (Third edition), Oxford: Oxford University Press.

Malt, H.E. (2008). Discussion Board Articles on Ratio Analysis Available on: www.eximfin.com

Mani, G.V. \& Sreedharan, R. (2004). Better Corporate Governance Pays. Insight in Risk, CRISIL Ratings.

Marlin, D. and Geiger, S.W. (2012). "The Composition of Corporate Boards of Directors: Does Industry Matter?" Journal of Business and Economics Research, vol.10, No.3, March, pp.157-162, The Clute Institute.

Matama, R. (2008). Corporate Governance and Financial Performance of Selected Commercial Banks in Uganda. CRRC. September 7 - 9, Available at: http://www.crrconference.org.

McCrae, R.R. and Costa, P.T. (1987). "Validation of the Five-Factor Model of Personality across Instruments and Observers.” Journal of Personality And Social Psychology, 52(1), 81.

McDonald, J.T. (1999). The Determinants of Firm Profitability in Australian Manufacturing. The Economic Record, 75 (229), pp.115-126.

McKinsey and Company (2007). Women Matter: Gender Diversity, A Corporate Performance Driver. Paris: McKinsey and Company, Available at: http://www.mckinsey.com

McManus, P.A (2011). Introduction to Regression Models for Panel Data Analysis. Indiana University, Workshop in Methods, October 7 Available on ssrc.indiana.edu Retrieved on March 25, 2015.

Metz, E.J. (1998). “Designing Succession Systems for New Competitive Realities.” Human Resource Planning, 21, pp.31-37.

Miller, S.E. (2009). "Governance mechanisms as moderators of Agency Costs in A Pre-SOX Environment." Economics Research, 7(10), pp. 15-32.

Mishra, A., Wilson, C., and Williams, R. (2009). Factors Affecting Financial Performance of new and Beginning Farmers. Agricultural Finance Review, 69 (2), pp. 160-179.

Mitropoulos, A. (2012) Contract and Contagion: From Biopolitics to Oikonomia. Wivenohoe: Minor Compositions/Autonomia.

Modigliani, F., and Miller, M.M. (1958). The Cost of Capital Corporation Finance and The Theory of Investment, American Economic Review, June, 48 (3), pp.261-297.

Monks, R.A.G. and Minow, N. (1995). Corporate Governance. Cambridge, M.A.: Blackwell.

(1996). Corporate Governance Mechanism. New York: Blackwell.

(2001). Corporate Governance ( $2^{\text {nd }}$ edition). Malden, M.A: Blackwell Publisher

Mukherjee, D., \& Ghosh, T. (2004). An Analysis of Corporate Performance and Governance in India: Study of Some Selected Industries. Indian Statistical Institute, New Delhi, India.

Mutalib, A. (2012). Corporate Governance and the Performance of Food, Beverage and Tobacco Industry in Nigeria. December, 20 (Abstract).

Myajima, H.,Orn, Y. and Saifo, N. (2003). "Corporate Governance and Performance in Twentieth Century Japan." Business and Economic History, Vol.1, pp.1 - 36

Nadler, D.A. (2004). Building Better Board. Harvard Business Review, May, pp.

Nanka - Bruce, D. (2009). Corporate Governance and Multi - Dimensional Performance. Doctoral Thesis, Universitat Autonoma de Barcelona.

Neubauer, F.F and Lank, A.G. (1998). The Family Business: Its Governance for Sustainability. New York: Routledge.

Nielson, J.D. (2000). The Role of Institutional Investors in Corporate Governance: Dilemma, Public Lecture Presented at Covenant University, Ota, Ogun State, January 25.

Nickell, S., Nicolitsas, D. and Dryden, N. (1997). "What makes Firms Perform Well?" European Economic Review, 41(2), pp.783-796.

Nnorom, N. (2015). Pearl Awards advised to include good Corporate Governance in its Award criteria. Vanguard newspaper, Friday, 20 March, 2015. Available on: www.vanguardngr.com

Nonaka, I. (1994). A Dynamic Theory of Organizational Knowledge Creation. Organization Science, Vol.5, pp. 14-37.

Norwani, N.M., Mohamad, Z.Z. and Chek, I.T. (2011)., "Corporate Governance Failure And Its Impact on Financial Reporting within Selected Companies.” International Journal of Business and Social Science, vol.2. No.21, November, Pp.205-213. Retrieved from: http://www.ijbsenet.com

Nunes, P.M. and Serrasqueiro, Z.S. (2008). Performance and Size: Empirical Evidence from Portuguese SMEs. Small Business Economics, 31(2), pp. 195-217.

Nunnaly, J. (1978). Psychometric Theory. New York: McGraw-Hill.

Nwonyuku, K.N. (2005). The Impact of Effective Funding and Control on the Attainment of a Firm's Objectives (A Case study of Vitafoam Nigeria Plc, Aba). A Research Project Report Presented in Partial Fulfilment for The Award of Higher National Diploma in School of Business Management and Technology, Department of Accounting, Abia State Polytechnic, Aba. 
(2012a). Corporate Governance Regulation: The Key Factor to Credible Financial Reporting in Nigeria. Available at: http://www.ssrn.com

(2012b). "Principles and Applications of Professional Ethics in Auditing." A Seminar Paper Presentation in the Department of Accounting, Ahmadu Bello University, Zaria.

(2015a). The Implications of Behavioural Management Accounting: A Contemporary Issue in Management Accounting. Cognitive Social Science e-Journal, Vol. 7, No. 168: September 22. Available at: http://www.ssrn.com

(2015b). The Role of Internal Auditors in the Management of Nigerian Public Sector Organizations: A Study of National Hospital, Abuja. Applied Accounting - Practitioner e-Journal, Vol. 7, No. 20: May

7. Available at: http://www.ssrn.com

(2015c). The Internal Control of Organizations: Value-synergy Approach. An Unpublished Work.

OECD, (2009). Observer. No. 273, June.

Office of the Superintendent of Financial Institutions, OSFI, Canada, (2013). Corporate Governance Guideline. Available at: http://www.osfi-bsif.gc.ca

Ofo, N. (2011a). Code of Corporate Governance in Nigeria 2011: Its Fourteen Fortes And Faults. Available at: papers.ssrn.com, October 3 .

(2011b). "Securities and Exchange Commission of Nigeria's Draft Revised Code of Corporate Governance: An Appraisal.” Available at: http://ssrn.com. Retrieved On: July 3, 2015.

Ogbechie, C. and Koufopoulos, D.N. (2010). Corporate Governance and Board Practices in the Nigerian Banking Industry, January.

Okeke C.C. (2001). Foundations of Educational and Behavioural Research: Issues and Methodology. Enugu: Academic Publishing Company.

Okereke, F (2013). Fundamental Concepts of Corporate Governance. A Paper delivered At the Pre - Induction Training Program, Organised by Chartered Institute of Loan And Risk Management of Nigeria, held on August 31, and October 4, in Abuja and Lagos Centres.

Okoye, N. (2012). "The Corporate Governance Code in Nigeria and the Behaviour and Personalities of Board Members: "A Stretch Beyond the Norms." International Company and Commercial Law Review, pp. 14.

Olaison, U.L., Jansson, A., Veldman, J. and Beverungen, A. (2013). The Political Economy Of Corporate Governance. Ephemera Theory and politics in Organization. Available on: www.ephemerajournal.org.

Oluwafemi, A.S., et al (2013). Corporate Governance and Firm Financial Performance: Do Ownership and Board Size Matter? Academic Journal of Interdisciplinary Studies MCSER Publishing, Rome - Italy, Vol.2, No.3, November; pp. $251-258$

Omondi, M.M. and Muturi, W. (2013). Factors Affecting the Financial Performance of Listed Companies at the Nairobi Securities Exchange in Kenya. Research Journal of Finance and Accounting. 4(15), pp. 99-105.

Organization of Economic Corporation and Development (OECD), (2004). The OECD Principles of Corporate Governance. Revised in April.

Orlikoff, J.E. and Totten, M.K. (2006). "Trustee Workbook: Trustee and Board Certification: A Future Trend?" Trustee, February. Available at: http://www.americangovernance.com

O'Sullivan, N. (2000). “The Impact of Board Composition and Ownership on Audit Quality: Evidence from Large UK Companies.” The British Accounting Review, 32, pp.397 - 414.

Oteh, A. (2013). "Enhancing Competitiveness through World Class Corporate Governance.” A Key Note Address at The $37^{\text {th }}$ Annual Conference of the Institute of Secretaries and Administrators of Nigeria (ICSAN), November 5, Lagos Director General, Securities and Exchange Commission Nigeria.

Owolabi, S.A. and Dada, S.O. (2011). "Audit Committee: An Instrument of Effective Corporate Governance." European Journal of Economics, Finance and Administrative Sciences. Retrieved from: http://www.eurojournals.com on December 17, 2012.

Owolabi, S.A., Obiakor, R.T. and Okwu, A.T. (2011). Investing Liquidity-Profitability relationship in Business organizations: A Study of Selected Quoted Companies in Nigeria. British Journal of Economics, Finance and Management Science, September, vol.1 (2). Retrieved from: http://www.ajournal.co.uk, on February 2, 2015.

Oyediran, C.O.O. (2003). Achieving Transparency in Corporate Governance: Issues, Modalities and Challenges. In Aloa, O. (ed.), Issues in Corporate Governance, Pp.60-70; Lagos, Financial Institution Training Centre.

Pablo, A., Valentine, A. and Felix, L. (2005). Corporate boards in OECD Countries: Size, Composition, Functioning and Effectiveness. Corporate Governance, vol.13, No.2, pp. 197-210.

Padachi, K. (2006). Trend in Working Capital Management and its Impact on Firms' Performance: An Analysis of Mauritian Small Manufacturing Firms. International Review of Business Research papers, 2(2), pp. 45-58. 
Pamela, P.D. (2009). Financial Ratio Analysis. Available on: http://www.wikipedia.org

Pande, S. (2011). Does Good Governance Pay? Evidence from Around the Globe. Retrieved from: http://dx.doi.org

Pandey, I.M. (2010). Financial Management (tenth edition). New Delhi: Vikas Publishing House PVT Ltd.

Panfilii, A. and Popa, I. (2012). "Failure of Corporate Governance-Intention or Negligence." Alexandria Group, June 6.

Pathirawasam, C. (2013). Internal Factors which Determine Financial Performance of Firms: With Special Reference to Ownership Concentration, pp. 62-72.

Pearce, J. and Zahra, S. (1991). "The Relative Power of CEOs and Boards of Directors: Associations with Corporate Performance." Strategic Management Journal, 12, pp. 135-153.

(1992). "Board Compensation from a Strategic Contingency Perspective." Journal Of Management Studies, 29(4), pp. 411-438.

Pettigrew, A.M. (1992). On Studying Managerial Elites. Strategic Management Journal, vol.13, No. 8, pp. 163182.

Pfeffer, J. (1973). "Size Composition and Function of Corporate Boards of Directors: The Organization Environment Linkage.” Administrative Science Quarterly, 18, pp.349 - 364.

(1983). Organizational Demography. In L.L. Cummings, and Staw, B.M. (Eds.), Research in Organizational Behaviour, 5, pp.299 - 357. Greenwich, CT: JAI Press.

Pfeffer, J. and Salancik, G.R. (1978). The External Control of Organizations: A Resource Dependence Perspective. New York: Harper and Row.

Porter, M.E. (1985). Competitive Advantage: Creating and Sustaining Superior Performance, New York. The Free Press.

Pound, J. (1993). The Rise of the Political Model of Corporate Governance and Corporate Control. New York University Law Review, vol.68, No.5, November, pp. 1003-1071.

Pound, J. (1983). Proxy Context and the Efficiency of Shareholder Oversight. Journal of Financial Economics, 20, pp. 237-265.

Power, W.W. (1991). Expanding the Scope of Institutional Analysis. In Abor, J. and Biekpe, N. (2007). Corporate Governance, Ownership Structure and Performance of SMEs in Ghana: Implications for Financial Opportunities. Corporate Governance, 7(3), Pp.288-300.

Pratheepan, T. (2014). A Panel Data Analysis of Profitability Determinants: Empirical Results from Sri Lankan Manufacturing Companies. International Journal of Economics, Commerce and Management, UK, Vol.11, Issue 12, December, pp.1-9., Available on: http://ijecm.co.uk.

Primeaux, P. "Maximizing Ethics and Profits," in Hartman L. (2002). Perspectives in Business Ethics, Second edition.

Provan, K. (1980). "Board Power of Organizational Effectiveness among Human Service Agencies.” Academy of Management Journal, 23, pp.221 - 236.

Prowse, S.D. (1998). Problems of External Finance and Corporate Governance: Emerging Issues and Lessons from East Asia. The World Bank Group, 29(2), Pp.3-14.

Prybil, L. (2008). What's Your Board's Culture? Trustee Magazine, June Issue.

Rajan, R.G. \& Zingales, L. (1995). What Do We Know about Capital Structure? Some Evidence from International Data. The Journal of Finance, December, 50 (5), pp.1421-1460.

Ravi, M.K. (2004). Financial Management. New Delhi: Taxman Allied Services Ltd.

Reed, J.S. (2003). Ethics and the Not-for-Profit Board. Boardroom Press, December, pp. 7.

Riahi - Belkaoui, A. (2002). Accounting Theory. (Fourth Edition). London: Thomson Learning.

Robe', J.P. (2011). The Legal Structure of the Firm. Accounting, Economics and Law, (1). Available on: http://www.works.bepress.com

Roberto, G. C. ,et al. (2008). Shareholder Vs. Stakeholder: Two Approaches to Corporate Governance. In: A Cross- National Study of Corporate Governance and Employment Contracts Blackwell. Available on: http://www.leseinsight.com, on March 25, 2015.

Roberts, D. (2004). Agency Theory Ethics of Corporate Governance. Maquarie Graduate School of Management, Sydney, Australia, Paper Prepared for the Corporate Governance and Ethics Conference.

Roberts, J. (2003). The Manufacture of Corporate Social Responsibility: Constructing Corporate Sensibility. Organization, 10(2), pp. 249-265.

Roberts, J. and Young, D. (2006). The Role of the Board in Creating a High Performance Organization. Available on: http://www.parcentre.com

Roberts, J. et al. (2005). "Beyond Conceptions of the Work of the Non - Executive Director: Creating Accountability in the Boardroom, Special Edition.” British Journal of Management, 16; pp.5 -26.

Roe, M. J. (1994). Strong Managers, Weak Owners: The Political Roots of American Corporate Finance. Princeton, New Jersey: Princeton University Press. (2003). Political Determinants of Corporate Governance: Political Context, Corporate Impact. New 
York: Oxford University Press.

Rose, C. (2007). "Does Female Board Representation Influence Firm Performance? The Danish Evidence." Journal Compilation. Blackwell Publishing Ltd, 15(2), Pp.404 - 413.

Rosenstein, S., and Wyatt, J. (1990). "Outside Directors, Board Independence and Financial Distress in Banking Firms.” International review of Economics and Finance, 8, 3, Pp.281 - 292.

Rossouw, D. (2005). Corporate Governance Trust in Business: A Matter of Balance. African Journal of Business Ethics, 1(2), pp.2-8.

Roth, K. and O’Donnell, S. (1996). "Foreign Subsidiary Compensation Strategy: An Agency Theory Perspective." Academy Journal of Management, 39(3), Pp.678-703.

Sachs, G. (2007). GS Sustain Focus List-God/man Sachs Global Investment Research.

Saleem, Q and Rehman, R.U. (2011). Impact of Liquidity Ratios on Profitability: Case of Oil and Gas Companies of Pakistan. Interdisciplinary Journal of Research in business, July, 1(7), pp. 95-98.

Sanda, A.U., Mikailu, A.S. and Garba, T. (2005). Corporate Governance Mechanisms And Frim Financial Performance in Nigeria African Economic Research Consortium. Research Paper No. 49, Nairobi: Kenya Regal Press.

Sanders, W.G and carpenter, M.A. (2003). Strategic Satisfying? A Behavioural Agency Perspective on Stock Repurchase Program Announcements. Academy of Management Journal, vol.46, pp. 160-179.

Scarborough, S., Haynie, J.J. and Shook, C. (2010). "Board Composition, Process and Activism: Evidence with American Firms." Management and Marketing, 5(1), Pp.3 - 18.

Scherrer, P.S. (2003). "Directors Responsibilities and Participation in the Strategic Decision Making Process." Corporate Governance, 3(1), pp.86-90.

Schultz, D. and Schultz, S.E. (1994). Theories of Personality, $5^{\text {th }}$ Edition. Pacific Grove, CT: Book/Cole Publishing.

SEBI (2003). Report of the SEBI Committee on Corporate Governance. SEBI. Available on: http://www.sebi.gov.in/cms/sebi_data.

Securities and Exchange Commission, SEC Nigeria (2003). Corporate Governance for Public Companies in Nigeria. Available on: http://www.sec.gov.ng.

Securities and Exchange Commission, - SEC (2011). Code of Corporate Governance For Public Companies in Nigeria. (2011). Available on: http://www.sec.gov.ng/code-of-corporate-governance-html.

Selvaggi, M. \& Upton, J. (2008). Governance and Performance in Corporate Britain. Report from the Association of British Insurers Research and Investment Affairs Departments.

Sharafa, O.M. (2014). Understanding Management Governance and Ethics. Lagos: Phodun Int'l Consulting Limited.

Shleifer, A. and Vishny, R. (1989). "Management Entrenchment: The Case of Manager Specific Investments." Journal of Financial Economics, 25, pp.123 - 140. (1997). "A Survey of Corporate Governance.” Journal of Finance, 52(2), Pp.737 - 783.

Siladi, B. (2006). The Role of Non - Executive Directors in Corporate Governance: An Evaluation Thesis Submitted in Fulfilment of the Requirement for the Degree Of Master of Business in the Faculty of Business and Enterprise, Swinburne University of Technology. Available: researchbank.swinburne.edu.au. Retrieved on: July 9, 2015.

Singh, H. \& Harianto, F. (1989). "Management-Board Relationships, Takeover Risk, And the Adoption of Golden Parachuts." Academy of Management Journal, 32, pp.7-24.

Small, J.E. (2000). "Making Boards More Effective." Health Progress. Vol. 81, No3; May-June. Available at: http://www.chausa.org.

Smith,Y. (2013). Why the "Maximizing Shareholder Value" Theory of Corporate Governance is Bogus. Available on: www.nakedcapitalism.com, on October 21.

Society for Corporate Governance Nigeria, SCGN (2014). Gender Diversity on Boards Of Publicly Quoted Companies in Nigeria. Vol.5 Issue1, November 1.

Sofowora, M.O. (2002). Modern Nigerian Company Law. Ikeja: Soft Associates.

Solomon, J., and Solomon, A. (2004). Corporate Governance and Accountability London: John Wiley and Sons Ltd.

Staff, (2000). "E-Business and Board Independence Key to Performance, Activists Say." Investor Relations Business, vol.1, pp. 16.

Statman, M.D. \& Glushkov, D. (2009). “The wages of Social Responsibility.” Financial Analysts Journal, 65, pp. 33-46.

Sternberg, E. (1996). "Stakeholder Theory Exposed.” Corporate Governance Quarterly, Hong Kong Institute of Company Secretaries, vol.2, No.1, March, pp. 4-18.

Stewart, D. and Kamins, M. (1992). Secondary Research: Information Sources And methods. London: SAGE Publications.

Stiglitz, J.E. (1969). A Re-Examination of the Modigliani - Miller Theorem. American Economic Review, 
December, 59 (5), pp. 784-794.

Sutton, J. (1997). Gibrat's Legacy. Journal of Economic Literature, March, 35(1), Pp. 40-59.

Tailab, M.M. (2014). Analysing Factors Effecting Profitability of Non-Financial U.S. Firms. Research Journal of Finance and accounting vol.5, No.22; pp. 17-26. Available on: http://www.iiste.org

Tanko, M. and Kolawole, O.O. (2007). Corporate Governance and Firm's Performance In Nigeria. Available at: http://ssrn.com

The 1999 Constitution of the Federal Republic of Nigeria (Amended).

The Nigerian Stock Exchange (2011). 2011-12 Fact book. Yaba: Eslia Communication

The Report of the Blue Ribbon Panel on Health Care Governance (2009). Competency- Based Governance: A Foundation for Board and Organizational Effectiveness. Centre for Healthcare Governance and Health Research and Educational Trust. Available at: americangovernance.com.

Tipgos, M.A. and Keefe, T.J. (2004). A Comprehensive Structure of Corporate Governance in Post - Enron Corporate America. The CPA Journal. Available at: http://www.nysscpa.org

Titman, S. (1988). The Journal of Finance, March, 43 (1), pp. 1-19.

Tornyeva, K. and Wereko, T. (2012). "Corporate Governance and Firm Performance: Evidence from the Insurance Sector of Ghana.” European Journal of Business And Management, Vol.4, No.13, pp.95 - 112. Available at: http://www.iiste.org

Tricker, R.I. (1994). International Corporate Governance. Singapore: Simon and Schuster. (1999). "Fat Cats and Englishmen.” Director, vol.52, No. 12, pp. 34.

Turnbull, S. (1997). Corporate Governance: Its Scope, Concerns \& Theories in Corporate Governance: An International Review, Blackwood, Oxford, Vol.5, No.4, October, pp. 180-205.

Tyson Report (2003). The Tyson Report on the Recruitment and Development Of Non-Executive Directors, USA. Department of Trade and Industries, June.

Uadiale, O.M. (2010). "The Impact of Board Structure on Corporate Financial Performance In Nigeria." International Journal of Business and Management, Vol.5, No.10; October; pp.155 - 166. Available on: Http://www.ccsenet,org/ijbm

Umer, U.M. (2014). Determinants of Capital Structure: Empirical Evidence from Large Taxpayer Share Companies in Ethiopia, International Journal of Economics and Finance; 6(1), pp.53-65.

Useem, W. (2006). How Well-Run Boards make Decisions. Harvard Business Review, pp. 130-138.

Vafeas, N. and Theodorou, E. (1998). "The Relationship between Board Structure and Firm Performance In the UK.” British Accounting Review, 30, 4, pp.383 - 407

Valsan, R. (2013). Board Diversity as a Corporate Governance Tool, Edinburgh Centre for Commercial Law. Available on: http://www.ecclblog.law.ed.ac.uk. December 2.

Van de Velde, E., Vermermeir, W. \& Corten, F. (2005). "Corporate Social Responsibility and financial Performance.” Corporate Governance, 5(3), pp. 129-138.

Van der Walt, N.T. and Ingley, C.B. (2001). "Evaluating Board Effectiveness: The hanging Context of Strategic Governance.” Journal of Change Management, vol.1, No.4, pp. 313 - 331.

(2003). "Board Dynamics and the influence of professional Background, Gender and Ethnic Diversity of Directors". Corporate Governance, 11 (3), 218-234

Vaus, de, D. (2011). Research Design in Social Research. London: SAGE Publications.

Velnampy, T. (2013). "Corporate Governance and Firm Performance: A Study of Sri Lankan Manufacturing Companies." Journal of Economics and Sustainable Development, Vol.4, No.3, pp.228 - 235. Available at: www.iiste.org.

Walker (2009). Report on Review of Corporate Governance in UK Banks and Other Financial Industry Ethics: Final Recommendations, November, 26.

Walsh, J.P. and Seward, J.K. (1990). "On the Efficiency of Internal and External Corporate -Control Mechanisms." Academy of Management Review, 15, Pp.421- 458.

Walt, N.V. and Ingley, C. (2003). "Board Dynamics and the Influence of Professional Background, Gender and Ethnic Diversity of Directors, Corporate Governance.” An International Review, 11(4), pp. 218 - 234.

Wan, F., Wan, Y. and Idris, A.A. (2012). "Insight of Corporate Governance Theories.” Journal of Business and Management.

Watson, E. (2004). Public Sector Corporate Governance: British Columbia's best- Practices Reforms. Ivey Business Journal Online, 1.

Weir, C., Laing, D., and McKnight, P.J. (2002). “Internal and External Governance Mechanisms: Their Impact on the performance of Large UK Public Companies.” Journal of Business Finance and Accounting, 29, pp.579-611.

Weisbach, M. (1988). Outside Directors and CEO Turnover. Journal of Financial Economics, Vol.20, pp. 431 460.

Weisman, C. (2003). "Building a Board with a Passion for the Mission.” Non-profit World, 21 (2), pp. 27 - 29. 
Wen, Y., Rwegasira, K. and Bilderbeek, J. (2002). 'Corporate Governance and Capital Structure Decisions of Chinese And Listed Firms'. Corporate Governance: An International Review, 10, 2, 75 - 83.

White, M.S. (2013). Strategic Actions: Strategy Implementation. Cenage Learning.

Wolfer, A. (2000). A Shareholder Value and Agency Theory Based Compensation System. Munich: GRIN Verlag. Available at: http://www.grin.com

Yawson, A. (2006). Evaluating the Characteristics of Corporate Boards Associated with Layoff decisions, Corporate Governance. An International Review; 14(2), Pp.75 - 84.

Yermack, D. (1996). Higher market valuation of Companies with a Smaller Board of Directors. Journal of Financial Economics, vol.40, pp. $185-211$.

Young, A. (2009). "Frameworks in Regulating Companies Directors: Rethinking the Philosophical Foundations to Enhance Accountability.” 30, Company Lawyer 335.

Yusoff, W.F.W. and Alhaji, I.A. (2012). Insight of Corporate Governance Theories. Journal of Business \& Management, volume1, Issue 1, pp. 52 - 63. Available on: www.todayscience.org

Zahra, S.A. and Pearce, II J.A. (1989). "Board of Directors and Corporate Financial Performance: A Review and Integrative Model.” Journal of Management, 15(2), 291-334. Retrieved from University of St. Gallen Library database.

Zajac, E. and Westpal, J. (1995). Accounting for the Explanations of CEO Compensation: Substance and Symbolism. Administrative Science Quarterly, 40(2); pp. 283-308.

Zald, M.N. (1969). "The Power and Functions of Board of Directors: A Theoretical Synthesis.” American Journal of Sociology, vol.75, pp. 97-111.

Zandstra, G. (2002). "Enron, Board Governance and Moral failings.” Corporate Governance, 2(2); pp.1619

Zubaidah, A.Z., Nurmala, K.M., and Kamaruzaman, J. (2009). Board Corporate Governance and Corporate Performance in Malaysia. International Journal of Economics and Finance, pp.150-164.

\section{APPENDIX 1}

\begin{tabular}{|c|c|c|c|c|c|c|c|}
\hline & \multicolumn{2}{|c|}{ TABLE 1: } & \multicolumn{5}{|c|}{ Result of the Descriptive Statistics Analysis } \\
\hline & ROE & NAPS & BS & BC & BSC & BGD & FS \\
\hline Mean & 0.072911 & 13.19059 & 1.002208 & 0.698195 & 1.000000 & 0.064861 & 10.60864 \\
\hline Median & 0.248050 & 10.03500 & 1.079180 & 0.714300 & 1.000000 & 0.000000 & 10.74710 \\
\hline Maximum & 3.025500 & 51.21360 & 1.146130 & 0.857140 & 1.000000 & 0.285700 & 11.47783 \\
\hline Minimum & -20.71000 & -2.757000 & 0.845100 & 0.461500 & 1.000000 & 0.000000 & 9.409880 \\
\hline Std. Dev. & 2.302489 & 11.43704 & 0.110157 & 0.121762 & 0.000000 & 0.089891 & 0.781449 \\
\hline Skewness & -8.472508 & 1.072277 & -0.349146 & -0.256934 & NA & 1.179289 & -0.517178 \\
\hline Kurtosis & 77.22760 & 3.794978 & 1.480040 & 1.960026 & NA & 3.249597 & 1.763224 \\
\hline Jarque-Bera & 21255.19 & 19.18072 & 10.25893 & 4.933892 & NA & 20.62569 & 9.531524 \\
\hline Probability & 0.000000 & 0.000068 & 0.005920 & 0.084844 & NA & 0.000033 & 0.008516 \\
\hline Sum & 6.416165 & 1160.772 & 88.19427 & 61.44116 & 88.00000 & 5.707810 & 933.5602 \\
\hline Sum Sq. Dev. & 461.2267 & 11380.11 & 1.055710 & 1.289864 & 0.000000 & 0.702997 & 53.12770 \\
\hline Observations & 88 & 88 & 88 & 88 & 88 & 88 & 88 \\
\hline Cross sections & 8 & 8 & 8 & 8 & 8 & 8 & 8 \\
\hline TAB & E 2: & Correla & $\begin{array}{l}\text { APPENDI } \\
\text { n Matrix: T }\end{array}$ & for Multi & linearity & & \\
\hline GUI & 7UP & FMILL & NNFMILL & NESTLE & CADBURY & NB & UTC \\
\hline 1 & 0.250457 & -0.267045 & 0.461874 & -0.064076 & -0.050372 & -0.342959 & -0.112533 \\
\hline 0.250457 & 1 & 0.106908 & -0.147754 & -0.094187 & 0.214834 & -0.235208 & -0.107530 \\
\hline-0.267045 & 0.106908 & 1 & -0.398557 & -0.251158 & -0.071494 & 0.141320 & 0.038906 \\
\hline 0.461874 & -0.147754 & -0.398557 & 1 & -0.200253 & -0.271709 & -0.326962 & -0.276648 \\
\hline-0.064076 & -0.094187 & -0.251158 & -0.200253 & 1 & -0.366112 & -0.184161 & -0.142647 \\
\hline-0.050373 & 0.214835 & -0.071494 & -0.271709 & -0.366120 & 1 & -0.155099 & 0.127425 \\
\hline-0.342960 & -0.235209 & 0.141321 & -0.326962 & -0.184161 & -0.155099 & 1 & -0.147744 \\
\hline-0.112534 & -0.107530 & 0.038906 & -0.276648 & -0.142647 & 0.127425 & -0.147743 & 1 \\
\hline
\end{tabular}




\section{APPENDIX 3}

Table 3.1: Analysis of Result of Regression Estimates for Prediction Model 1 Dependent Variable: ROE

Method: Pooled Least Squares

Date: 11/27/15 Time: 22:46

Sample: 2004 - 2014

Included observations: 11

Cross-sections included: 8

Total pool (balanced) observations: 88

\begin{tabular}{crlrl}
\hline \hline \multicolumn{1}{c}{ Variable } & Coefficient & Std. Error & t-Statistic & Prob. \\
\hline \hline BS & 4.945574 & 2.696277 & 1.834223 & 0.0702 \\
BC & -0.669708 & 2.142920 & -0.312521 & 0.7554 \\
BSC & -4.722703 & 3.570439 & -1.322723 & 0.1896 \\
BGD & 4.761343 & 3.147102 & 1.512930 & 0.1341 \\
FS & $-1.99 E-06$ & $2.53 E-05$ & -0.078709 & 0.9375 \\
\hline \hline R-squared & 0.054391 & Mean dependent var & 0.072911 \\
Adjusted R-squared & 0.008819 & S.D. dependent var & 2.302489 \\
S.E. of regression & 2.292313 & Akaike info criterion & 4.552140 \\
Sum squared resid & 436.1402 & Schwarz criterion & 4.692898 \\
Log likelihood & -195.2942 & Hannan-Quinn criter. & 4.608848 \\
Durbin-Watson stat & 2.323135 & & & \\
\hline \hline
\end{tabular}

* Significant at 5\% (0.05) level of significance

*Source: E - Views version 8.0

Table 3.2: Analysis of Result of Regression Estimates for Prediction Model 2

Dependent Variable: NAPS

Method: Pooled Least Squares

Date: 11/27/15 Time: 22:48

Sample: 2004 - 2014

Included observations: 11

Cross-sections included: 8

Total pool (balanced) observations: 88

\begin{tabular}{|c|c|c|c|c|}
\hline Variable & Coefficient & Std. Error & t-Statistic & Prob. \\
\hline $\mathrm{BS}$ & 50.01826 & 12.38496 & 4.038630 & 0.0001 \\
\hline $\mathrm{BC}$ & 3.502719 & 9.843194 & 0.355852 & 0.7229 \\
\hline $\mathrm{BSC}$ & -41.92652 & 16.40029 & -2.556449 & 0.0124 \\
\hline BGD & 40.80849 & 14.45575 & 2.822992 & 0.0060 \\
\hline FS & $-9.78 \mathrm{E}-05$ & 0.000116 & -0.841210 & 0.4026 \\
\hline R-squared & 0.191389 & Mean dependent var & & 13.19059 \\
\hline Adjusted R-squared & 0.152420 & S.D. dependent var & & 11.43704 \\
\hline S.E. of regression & 10.52941 & Akaike info criterion & & 7.601362 \\
\hline Sum squared resid & 9202.082 & Schwarz criterion & & 7.742119 \\
\hline Log likelihood & -329.4599 & Hannan-Quinn criter. & & 7.658069 \\
\hline Durbin-Watson stat & 2.014231 & & & \\
\hline
\end{tabular}

* Significant at 5\% (0.05) level of significance

*Source: E - Views version 8.0 
APPENDIX 4

Table 4: Summary and Conclusion of Results of Regression Estimates for the Relationship between Corporate Governance and Profitability of Listed Food and Beverages Firms in Nigeria for the period of 11 years, spanning from $2004-2014$.

\begin{tabular}{|c|c|c|c|}
\hline Variable & ROE & NAPS & Conclusion \\
\hline Board Size (BS) & $\begin{array}{l}\text { Positive and } \\
\text { Insignificant }\end{array}$ & $\begin{array}{l}\text { Positive } \\
\text { Significant }\end{array}$ & $\begin{array}{l}\text { The size of the board of directors has a positive } \\
\text { relationship with profitability of food and } \\
\text { beverages firms in Nigeria. }\end{array}$ \\
\hline $\begin{array}{l}\text { Board } \\
\text { Composition } \\
\text { (BC) }\end{array}$ & $\begin{array}{l}\text { Negative and } \\
\text { Insignificant }\end{array}$ & $\begin{array}{ll}\text { Positive } & \text { and } \\
\text { Insignificant } & \end{array}$ & $\begin{array}{l}\text { There are mixed and inconclusive results between } \\
\text { board composition and profitability of food and } \\
\text { beverages firms in Nigeria. }\end{array}$ \\
\hline $\begin{array}{l}\text { Board Skills and } \\
\text { Competence } \\
\text { (BSC) }\end{array}$ & $\begin{array}{l}\text { Negative and } \\
\text { Insignificant }\end{array}$ & $\begin{array}{l}\text { Negative } \\
\text { Insignificant }\end{array}$ & $\begin{array}{l}\text { Board skills and competence has negative } \\
\text { relationship with profitability of food and } \\
\text { beverages firms in Nigeria. }\end{array}$ \\
\hline $\begin{array}{l}\text { Board Gender } \\
\text { Diversity (BGD) }\end{array}$ & $\begin{array}{l}\text { Positive and } \\
\text { Insignificant }\end{array}$ & $\begin{array}{l}\text { Positive } \\
\text { Significant }\end{array}$ & $\begin{array}{l}\text { There is positive correlation between board gender } \\
\text { diversity and profitability of food and beverages } \\
\text { firms in Nigeria. }\end{array}$ \\
\hline Firm Size (FS) & $\begin{array}{l}\text { Negative and } \\
\text { Insignificant }\end{array}$ & $\begin{array}{ll}\text { Negative } & \text { and } \\
\text { Insignificant } & \end{array}$ & $\begin{array}{l}\text { There is negative and weak relationship between } \\
\text { firm size and profitability of food and beverages } \\
\text { firms in Nigeria. }\end{array}$ \\
\hline
\end{tabular}

*Significant at $5 \%(0.05)$ level of significance

*Source: E - views version 8.0 